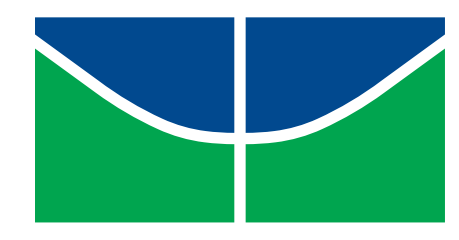

\author{
Universidade de Brasília \\ Instituto de Ciências Exatas \\ Departamento de Matemática
}

Expressões algébricas na Educação Básica: a validação de atividades de ensino e aprendizagem

por

Ludimila Cássia Coelho de Andrade

Brasília, 2016 
Ludimila Cássia Coelho de Andrade

Expressões algébricas na Educação Básica: a validação de atividades de ensino e aprendizagem

Dissertação apresentada ao Departamento de Matemática da Universidade de Brasília, como parte dos requisitos para a obtenção do grau de

\section{Mestra em Matemática}

Orientadora: Prof. Dra. Regina da Silva Pina Neves

Brasilia

2016 
Universidade de Brasília

Instituto de Ciências Exatas

Departamento de Matemática

\title{
Expressões algébricas na Educação Básica: a validação de atividades de por ensino e aprendizagem
}

\author{
Ludimila Cássia Coelho de Andrade ${ }^{1}$
}

Dissertação apresentada ao Departamento de Matemática da Universidade de Brasília, como parte dos requisitos para obtenção do grau de

\section{MESTRA EM MATEMÁTICA}

Brasília, 22 de julho de 2016

Comissão Examinadora:
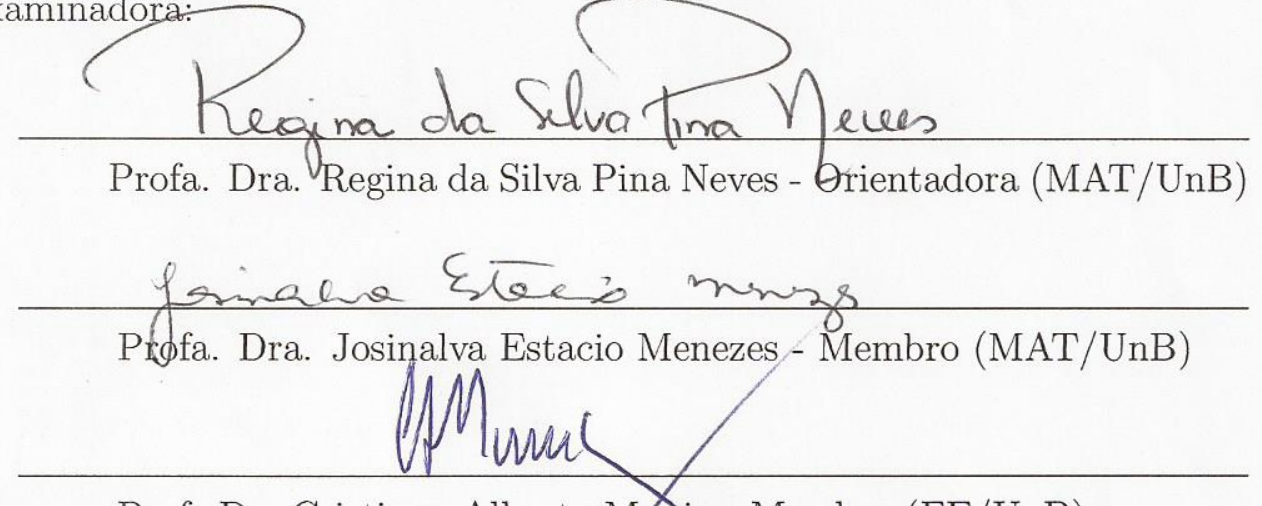

Prof. Dr. Cristiano Alberto Myinz - Membro (FE/UnB)

\footnotetext{
${ }^{1} \mathrm{~A}$ autora foi bolsista da CAPES durante a elaboração desse trabalho.
} 
Dedico este trabalho à minha família, pelo amor que sempre me dedicaram pelo esforço e sacrifícios para que eu tivesse acesso a educação, e também pelo apoio incondicional.

À vocês o meu amor e reconhecimento eterno... 


\section{Agradecimentos}

Neste momento importante, venho, com todo meu apreço e sinceridade, agradecer àqueles que contribuíram para o sucesso deste trabalho e desta importante fase de meu desenvolvimento pessoal e profissional.

Primeiramente gostaria de agradecer aos meus pais Eurípedes Coelho de Andrade e Aparecida Esméria da Silva Andrade e ao meu irmão Eurípedes Coelho de Andrade Júnior pelo amor dedicado, bem como pelo esforço para que eu tivesse acesso à educação e também à formação superior.

Aos meus familiares, avó Terezinha, tios Rubens, Avelina e Joaquim e primos Ana Paula, Sérgio, Júlia e Jaqueline que sempre contribuíram para minha permanência na universidade. Ao meu amor Thiago Couto por toda a paciência, suporte e compreensão durante os períodos de produção.

Sou grata a minha orientadora Dra. Regina Pina que, desde o primeiro momento, se dispôs a me orientar, ensinando-me afetuosamente, o verdadeiro sentido de "Vamos que vamos!" e com paciência e muita disposição me acompanhou e deu todo o suporte para que este trabalho fosse desenvolvido.

Rendo homenagens a todos os amigos que fiz na cidade de Brasília e aos amigos matemáticos que partilham o desafio de morar distante de suas famílias. Aos professores da Universidade Federal de Goiás, os precursores do meu engajamento no ensino de matemática. Ao professor Dr. Wellington Cedro e parceiros do Clube de Matemática com os quais tive a honra de desenvolver um trabalho inspirador.

Faço referência aos meus amigos da CAJU, Daniele, Amanda e Edmilson, com quem continuo a aprender, aos meus colegas de trabalho, em especial as amigas Ana Lúcia e Suely, que vivenciam diariamente as alegrias e desafios de se ensinar. Aos meus colegas do curso PROFMAT, em especial a Luana e o Augusto, que tornaram-se amigos e cada vez mais parceiros durante esta caminhada.

Agradeço a compreensão nas vezes em que me fiz ausente. Enfim, agradeço a todos que contribuíram para que hoje este trabalho pudesse ser concluído. 


\section{Resumo}

O processo de ensino e aprendizagem de álgebra apresenta-se como um desafio para os professores de Matemática. As pesquisas nessa área apontam que, de maneira geral, os professores ensinam apenas técnicas para a execução de cálculos com sucesso. Lima(2007) e Ribeiro(2012) apontam que as dificuldades dos professores em dar significado aos conteúdos algébricos, bem como planejar ações que garantam o ensino entrelaçado aos contextos reais, refletem nas dificuldades conceituais dos alunos em relação a esses conteúdos, dificultando a aprendizagem. Lins e Gimenez (1997) e Kieran (2004) cientes da necessidade de construção dos conceitos algébricos a partir das experiências já vivenciadas pelos estudantes, ressaltam a importância do desenvolvimento do pensamento algébrico desde os anos iniciais. Sendo assim, o objetivo desse trabalho é validar atividades para o ensino e aprendizagem de expressões algébricas junto a professores da Educação Básica da Secretaria de Estado e Educação do Distrito Federal. A pesquisa foi realizada no Laboratório de Educação Matemática do Departamento de Matemática da Universidade de Brasília e contou com a participação de 8 professores de matemática da Secretaria de Estado e Educação do Distrito Federal, atuantes em salas de aula da Educação Básica. Durante o encontro, os participantes vivenciaram as atividades, assumindo o papel dos estudantes e, posteriormente, dialogaram sobre o processo de ensino e aprendizagem de álgebra, bem como sobre o desenvolvimento das atividades de ensino, perfazendo o processo de validação. Como resultados, apontamos a relevância da formação continuada, do permanente diálogo e troca de experiências entre os professores afim de aprimorar as metodologias e ações voltadas para o ensino de Matemática e especialmente o de Álgebra. Compreendemos que foi fundamental a avaliação das atividades de ensino a partir de pontos de vista de professores experientes e atuantes em salas de aula da Educação Básica, pois possibilitou identificar limitações, potencialidades, bem como, discutir e reelaborar as atividades, adaptando-as às necessidades do processo de ensino-aprendizagem.

Palavras-chave: Atividades de Ensino, Ensino Fundamental Anos Finais, Expressões Algébricas. 


\section{Abstract}

The process of teaching and learning algebra still presents itself as a challenge for mathematics teachers. Researches in this area show that, in general, teachers only teach techniques to successfully perform calculations. Lima (2007) and Ribeiro (2012) point out that the difficulties of teachers in giving meaning to the algebraic content, as well as planning the efforts to ensure that the teaching is interlaced to real contexts, reflect the conceptual difficulties of students regarding such content, making it difficult to learn. Lins and Gimenez (1997) and Kieran (2004) aware of the need to build the Algebraic concepts based on the experiences already lived by students, highlight the importance of developing algebraic thinking since the early years. Therefore, this study aims at validating activities for teaching and learning algebraic expressions together with Elementary School teachers of the Secretaria de Estado de ção do Distrito Federal (State Secretariat of Education of the Federal District). The research was conducted in the Mathematics Education Laboratory of the Mathematics Department at the University of Brasilia and had the participation of 8 teachers. During the session, the participants experienced three activities and dialogued about the process of teaching and learning algebra, as well as about the development of educational activities, making the validation process. As results, we point out the relevance of the continuing education, the ongoing dialogue and the exchange of experience among teachers, in order to improve methodologies and actions aimed at teaching Math and especially Algebra. We understand that it was essential to assess the teaching activities from the points of view of experienced teachers who are active in Elementary Education classrooms, because it enabled the identification of limitations, potentials and also the discussion and rework of activities, adapting them to the needs of the teaching and learning processes.

Keywords: Teaching Activities, Final Years of Elementary School, Algebraic Expressions. 


\section{Sumário}

$\begin{array}{ll}\text { Introdução } & 1\end{array}$

\begin{tabular}{|ll}
1 & Historicidade do objeto
\end{tabular}

2 A álgebra na Educação Básica $\quad 16$

2.1 A construção histórica do ensino de álgebra $\quad$. . . . . . . . . . . . . . 16

2.2 A matemática e a álgebra nas avaliações nacionais e internacionais . . . 21

2.3 O Ensino e Aprendizagem de Álgebra . . . . . . . . . . . . . . . . . . . . 28

2.4 A passagem da aritmética para a álgebra: algumas considerações . . . . 34

3 Diálogo sobre o ensino de álgebra via livro didático do Ensino Fundamental Anos Finais. 38

3.1 O livro didático escolhido . . . . . . . . . . . . . . . . . . . . . 41

3.2 Os capítulos do livro dedicados ao ensino de Álgebra . . . . . . . . . . 44

4 A relevância da experiência no processo de ensino e aprendizagem de matemática. $\quad 50$

$4.1 \quad$ O que é a experiência? . . . . . . . . . . . . . . . . . . 50

$4.2 \quad$ O clube de matemática $\ldots \ldots \ldots \ldots \ldots$. . . . . . . . . . . . . 53

4.3 As atividades de ensino e jogos escolhidos . . . . . . . . . . . . . 55

4.3 .1 Boliche Matemático . . . . . . . . . . . . . . . . . . 56

4.3 .2 Trilha das Leis . . . . . . . . . . . . . . . . . . . . . . . 60

4.3 .3 Batalha Naval . . . . . . . . . . . . . . . . . . . . . . . . . . . . 63

$\begin{array}{lll}5 & \text { Método } & 67\end{array}$

5.1 o cenário . . . . . . . . . . . . . . . . . . . . 72

5.2 Os participantes . . . . . . . . . . . . . . . . . . . . 74

5.3 Instrumentos e Procedimentos . . . . . . . . . . . . . . . . . 76

5.4 Questionário . . . . . . . . . . . . . . . . . . . . . . 77 
$5.5 \quad$ Organização do material $\ldots \ldots \ldots$. . . . . . . . . . . . . . . . . 78

5.6 Análise das informações . . . . . . . . . . . . . . . . . . . . . 80

6 Construção das informações para a análise 82

6.1 Análise dos questionários . . . . . . . . . . . . . . . . . . . . 82

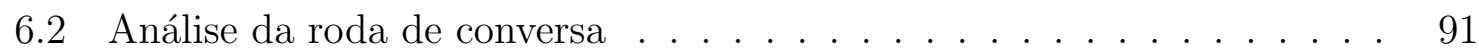

6.3 Conclusões . . . . . . . . . . . . . . . . . . . . . . . . . . . . . . . . . . . . 110

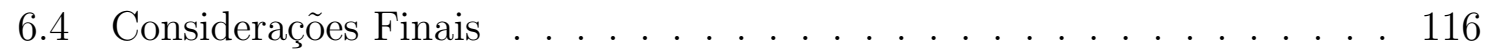

\begin{tabular}{ll}
\hline Referências Bibliográficas & 118
\end{tabular}

\begin{tabular}{ll}
\hline A Apêndice & 126
\end{tabular}

\begin{tabular}{ll}
\hline Apêndice A & 126
\end{tabular} 


\section{Lista de Figuras}

$2.1 \quad$ Escala proficiência em Matemática - PISA 2012 (INEP,2012). . . . . . . 22

2.2 Resultados do PISA para matemática em alguns países (INEP, 2012,

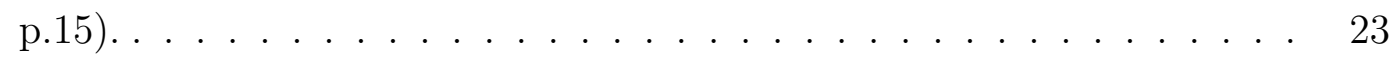

2.3 Distribuição dos estudantes brasileiros nos níveis de proficiência do PISA 2013 e 2012 (INEP, 2012, p.21). . . . . . . . . . . . . . . . . . . . . . 24

$2.4 \quad$ Item de matemática - Prova Brasil (IT_025075) . . . . . . . . . . . . 26

$2.5 \quad$ Item de matemática - Prova Brasil (IT_021185) . . . . . . . . . . . . . 27

$2.6 \quad$ Interpretações da álgebra escolar (Brasil, 1998, p.116). . . . . . . . . . 30

$3.1 \quad$ Exercício. (DANTE, 2015, p.29) . . . . . . . . . . . . . . . . 42

3.2 Propriedade do produto de potências de mesma base - (DANTE, 2015,

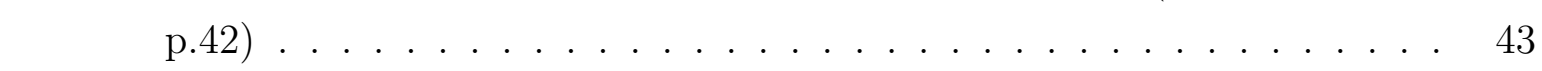

$3.3 \quad$ Exercícios. (DANTE, 2015, p.65) . . . . . . . . . . . . . . 43

3.4 Máquinas de números. (DANTE, 2015, p.117.) . . . . . . . . . . . . . 45

3.5 Exemplo de expressão algébrica aplicada à contextos geométricos e Grandezas e Medidas. (DANTE, 2015, p.120.) . . . . . . . . . . . . . . . 45

$3.6 \quad$ Exemplo de equações utilizando uma balança. (DANTE, 2015, p.134.). 46

3.7 Resolução de situações-problema usando sistemas. (DANTE, 2015, p.165.) 47

$4.1 \quad$ Folha de Registro Boliche Matemático - $1^{\circ}$ momento . . . . . . . . . . 57

4.2 Folha de Registro Boliche Matemático - $2^{\circ}$ momento . . . . . . . . . . 59

4.3 Cartas com as funções para a atividade Trilha das Leis . . . . . . . . . 60

4.4 Tabuleiro da atividade Trilha das Leis . . . . . . . . . . . . . . . . 61

$4.5 \quad$ Folha de registro da atividade Trilha das Leis . . . . . . . . . . . . . 62

4.6 Campo de batalha da atividade Batalha Naval . . . . . . . . . . . . . 63

4.7 Exemplo de correspondência Campo de Batalha . . . . . . . . . . . . . 64

4.8 Folha de registro da atividade Batalha Naval . . . . . . . . . . . . . . . 65 
$5.1 \quad$ Foto do espaço LEMAT $/ \mathrm{UnB} \quad \ldots \ldots \ldots \ldots$

5.2 Alguns materiais manipuláveis do LEMAT/UnB . . . . . . . . . . . . . 74

5.3 Materiais preparados para aplicação das atividades de ensino . . . . . . 78

$6.1 \quad$ Faixa etária de professores da Educação Básica no DF, 2007. . . . . . . 83

6.2 Resposta do P4 para o item 1 do questionário. . . . . . . . . . . . . . . 84

6.3 Resposta da Pa3 para o item 1 do questionário . . . . . . . . . . . . . . 85

6.4 Resposta do P5 para o item 1 do questionário. . . . . . . . . . . . . . . 85

6.5 Resposta do P2 para o item 1 do questionário. . . . . . . . . . . . . . . 86

6.6 Resposta do P1 para o item 2 do questionário. . . . . . . . . . . . . . . 87

6.7 Resposta do P3 para o item 2 do questionário. . . . . . . . . . . . . . . 88

6.8 Resposta do P5 para o item 2 do questionário . . . . . . . . . . . . . 89

6.9 Resposta da Pa3 para o item 3 do questionário . . . . . . . . . . . . . . 89

6.10 Resposta da Pa2 para o item 3 do questionário . . . . . . . . . . . . . . 90

6.11 Resposta do P3 para o item 3 do questionário . . . . . . . . . . . . . . 90

6.12 Resposta do P1 para o item 3 do questionário . . . . . . . . . . . . . . 91

A.1 Questionário de identifição dos participantes - Parte 1 . . . . . . . . . . 127

A.2 Questionário de identifição dos participantes - Parte 2 . . . . . . . . . . 128

A.3 Termo de Consentimento Livre e Esclarecido (TCLE) - p.1 . . . . . . . 129

A.4 Termo de Consentimento Livre e Esclarecido (TCLE) - p.2 . . . . . . . 130

A.5 Atividade Potências e Raízes elaborada por P1 - momento 1 . . . . . . 131

A.6 Atividade Potências e Raízes elaborada por P1 - momento 2 . . . . . . 131

A.7 Atividade Inteiros na Reta elaborada por P1 - momento 1 . . . . . . . 132

A.8 Atividade Inteiros na Reta elaborada por P1 - momento 2 . . . . . . . 132 


\section{Lista de Tabelas}

$1.1 \quad$ Jogos: Nim, Hackenbush, Kayles, Domineering, Brotas e Hex. . . . . . 8

2.1 Pesquisas em Álgebra . . . . . . . . . . . . . . . . . . . . . . . . . . . . . . . . 19

2.2 Avaliações realizadas pelo SAEB $\ldots \ldots \ldots$. . . . . . . . . . . 25

2.3 Categorias de um perfil conceitual de equação. . . . . . . . . . . . . . . 36

2.4 Categorias de um perfil conceitual de função. . . . . . . . . . . . . . . . 37

3.1 Livro didático Matemática - Projeto Teláris. . . . . . . . . . . . . . . . 41

4.1 Atividade Boliche Matemático . . . . . . . . . . . . . . . . . . . 56

4.2 Atividade Trilha das Leis . . . . . . . . . . . . . . . . . . . . . . . 56

4.3 Atividade Batalha Naval . . . . . . . . . . . . . . . . . . . . . . . . . . 56

5.1 Instrumentos utilizados e objetivos da pesquisa $\ldots \ldots$. . . . . . . . 76

5.2 Programação da sessão realizada com os participantes da pesquisa. . . . $\quad 79$

5.3 Três momentos - Análise de conteúdo proposta por Bardin . . . . . . . 80

6.1 Roda de conversa - Categoria 1 . . . . . . . . . . . . . . . . 101

6.2 Roda de conversa - Categoria 2 . . . . . . . . . . . . . . 109 


\section{Introdução}

Essa pesquisa propôs a validação de três atividades de ensino: Boliche $M a$ temático, Trilha das Leis e Batalha Naval junto a oito professores da Educação Básica atuantes na Secretaria de Estado de Educação do Distrito Federal (SEE-DF). As atividades de ensino propostas nesse trabalho, foram construídas e utilizadas com os estudantes participantes do projeto Clube de Matemática, desenvolvido pelo Laboratório de Educação Matemática da Universidade Federal de Goiás (LEMAT/UFG) no ano de 2011 e visam auxiliar o processo de ensino e aprendizagem de expressões algébricas.

Essas três atividades foram escolhidas por discutirem a relação de dependência entre função e variável, além de se apresentarem como mais um instrumento para a compreensão do conceito de variável, que, muitas vezes, não é entendido pelos estudantes, dificultando a construção e o desenvolvimento algébrico dos mesmos. Todavia, ressaltamos que essas atividades compõem o primeiro módulo e estão associadas a outras sete atividades divididas em módulos seguintes do Clube de Matemática para o ensino e aprendizagem de expressões algébricas.

Primeiramente, relatamos a historicidade do objeto, expondo os aspectos da trajetória de vida relacionada ao ensino e aprendizagem de matemática, tanto como discente na Educação Básica, considerando as experiências e habilidades desenvolvidas a partir dos conteúdos matemáticos, e mais tarde como estudante de um curso de licenciatura em matemática, marcado por experiências significativas vivenciadas dentro do espaço LEMAT, e atualmente, como docente, que reflete sobre as diversas influências e inquietações que surgem dentro do contexto de ensinar matemática, e que foram cruciais para a escolha do tema e delineamento da pesquisa.

Considerando as inquietações relacionadas ao ensino e aprendizagem de matemática e mais especificamente de álgebra, propomos no segundo capítulo a discussão acerca do ensino e aprendizagem de álgebra na Educação Básica, partindo de pesquisas que apontam as dificuldades dos estudantes relacionadas a esse conteúdo, buscando compreendê-las a partir dos pontos de vista dos autores que pesquisam e são referência 
nessa área.

O terceiro capítulo mostra como o ensino de álgebra é formalmente iniciado no Ensino Fundamental Anos Finais, a partir da observação do livro didático Projeto Teláris do autor Luiz Roberto Dante, livro utilizado pela maioria dos professores participantes da pesquisa, e ainda pelas escolas nas quais lecionam. Apontamos e exemplificamos como o autor aborda os conteúdos de Expressões Algébricas e Equações do $1^{\circ}$ grau, afim de compreender a transição entre aritmética e álgebra e, ainda, referenciamos a abordagem feita pelo autor, quando comparada a proposta desse trabalho de pesquisa.

A partir daí, discutimos no quarto capítulo a importância dos processos de investigação em sala de aula, bem como da experimentação por parte dos estudantes, considerando que a matemática ainda é percebida de forma abstrata e distante dos contextos reais. Logo, apresentamos a proposta desenvolvida pelo Clube de Matemática, com estudantes da rede pública de ensino do estado de Goiás, bem como o detalhamento das três atividades de ensino utilizadas no trabalho, para as quais propomos o processo de validação.

Feitas essas explanações, descrevemos o percurso metodológico, uma vez que trata-se de uma pesquisa qualitativa. Como instrumentos para a construção de informações para análise, utilizamos questionários e filmagens dos diálogos entre os participantes e pesquisadora.

A construção de informações para a análise é feita a partir do capítulo seis, no qual, a pesquisadora utiliza o processo de categorização preconizado por Bardin (2011), propondo duas categorias: Concepção dos professores sobre o ensino e aprendizagem de álgebra, incluindo a organização do trabalho pedagógico e A validação das atividades para o ensino e a aprendizagem de álgebra. Em cada categoria, foram identificados elementos significativos relacionados aos processos de ensino e aprendizagem de álgebra, bem como de validação das três atividades de ensino. As informações analisadas foram apresentadas na ordem em que foram propostas durante a sessão com os professores, partindo dos questionários e chegando-se aos diálogos.

Os resultados foram construídos junto com as análises, considerando a bibliografia utilizada para a construção da pesquisa. Por meio de questionários e da roda de conversa os participantes fizeram apontamentos considerando design, funcionalidade, desenvolvimento e análise pedagógica para cada uma das atividades de ensino. Sugeriram outros conteúdos matemáticos que podem ser trabalhados por meio dessas atividades e também propostas de reformulação.

Considerando os apontamentos dos participantes observamos a importância de espaços de formação continuada que permitam o diálogo, troca de experiências, cons- 
trução de possíveis soluções, contribuindo para superação de alguns desafios que se apresentam no dia a dia dos professores de matemática atuantes na Educação Básica, fazendo alguns apontamentos à respeito de como o ensino de matemática é abordado nesses espaços de formação das licenciaturas em matemática. 


\section{Capítulo 1}

\section{Historicidade do objeto}

Neste capítulo inicial, peço licença ao leitor, para utilizar a primeira pessoa do tempo verbal no texto, tendo em vista a relevância dos processos de desenvolvimento pessoal e profissional relacionados ao conhecimento matemático, expondo algumas experiências vivenciadas desde a infância até os dias atuais. Tais experiências foram determinantes não só para a minha escolha profissional, mas também responsáveis pela forma de compreender e vivenciar o processo de ensino e aprendizagem de matemática.

Minha relação com a matemática iniciou-se quando ainda era bem pequena. Nesse primeiro momento, antes mesmo de ingressar na escola, o contato foi com noções de matemática financeira, estabelecendo relações entre os valores das cédulas e das moedas, maior que, menor que e também imaginando as possibilidades de compra de balas e pirulitos que o troco poderia me proporcionar.

Na rua onde morava, havia quatro garotas com idades próximas a minha com as quais eu brincava de escola. Durante essas brincadeiras, eu queria ser a professora, sempre, mesmo disputando com colegas um pouco mais velhas. Enfim, já eram os primeiros apontamentos para a minha futura escolha profissional.

Cansados de verem o tanque da área de serviço todo sujo de giz, meus pais decidiram me presentear com um quadro negro e um apagador. Tal ação foi o que eu precisava para dar continuidade a minha trajetória como professora e alfabetizadora de grande parte das crianças do meu bairro.

Durante toda a formação escolar, a minha disciplina preferida foi matemática, apresentava excelente desempenho e fui "monitora" "1 das "aulas de reforço" [2 e "grupos de estudo"3. Mais tarde, o gosto pelo ensino e pela matemática foi unificado e antes

\footnotetext{
${ }^{1}$ Monitora - termo usado para designar um estudante que presta assistência aos demais, auxiliando no trabalho do professor.

${ }^{2}$ Aulas de reforço - aulas extracurriculares nas quais professores e/ou estudantes com melhor desempenho em determinada disciplina auxiliam os outros estudantes com dificuldades.

${ }^{3}$ Grupos de estudo - grupos com um número reduzido de estudantes, que se reúnem para discutir e aprofundar os conteúdos estudados em suas aulas, promovendo aprendizagem de forma colaborativa.
} 
mesmo de concluir o ensino médio, me tornei professora particular de matemática. Nos bairros onde morei, muitos alunos precisavam de reforço no fim do ano e recorriam a mim para que pudesse ensiná-los.

Apesar desse intenso relacionamento com a matemática, minha primeira opção de curso para o vestibular foi farmácia. No entanto, o desempenho na prova específica de biologia foi insuficiente, enquanto na prova de matemática foi muito melhor do que o previsto. No ano seguinte, por perceber minha dedicação à matemática e à física, durante o curso pré-vestibular, mudei minha opção de cursar farmácia para o curso de matemática. Obtive êxito na escolha, sendo aprovada em primeiro e terceiro lugar nos vestibulares das Universidade Estadual de Goiás (UEG) e Universidade Federal de Goiás (UFG), respectivamente.

Em 2006, já no primeiro ano do meu curso de matemática, tive contato com o Laboratório de Educação Matemática (LEMAT) do Instituto de Matemática e Estatística da Universidade Federal de Goiás (IME/UFG), em princípio, como aluna, explorando-o fisicamente e utilizando o ambiente para estudar e acessar os computadores que disponibilizavam para os alunos.

O LEMAT 4 , idealizado pela professora Zaíra da Cunha Melo Varizo, com o auxílio de sua ex aluna de graduação Silmara Epifânia de Castro Carvalho, atualmente aposentada como técnica em assuntos educacionais, teve seu projeto de criação aprovado em 1993 e, em agosto de 1994, foi instalado e começou a funcionar em uma pequena sala no andar superior do IME/UFG. Para conhecer melhor a história do LEMAT sugiro a leitura do livro "Olhares e reflexões acerca de concepções e práticas no Laboratório de Educação Matemática5', organizado por Varizo e Civardi(2011). Atualmente, o LEMAT desenvolve projetos de tutoria ${ }^{6}$ a estudantes e assessoria 7 a professores, relacionados ao ensino e aprendizagem de matemática.

\footnotetext{
${ }^{4}$ Site do LEMAT: https://lemat.mat.ufg.br/, acesso em 27 maio 2016.

${ }^{5}$ Autoras: Zaíra da Cunha Melo Varizo, Jaqueline Araújo Civardi, Luciana Parente Rocha, Regina da Silva Pina Neves, Silmara Epifânia de Castro Carvalho e Susane Fernandes de Abreu Teixeira. Esta obra retrata experiências de formação profissional de educadoras matemáticas desenvolvidas no contexto de um laboratório de educação matemática. Fonte: https://www.editoracrv.com.br/index.php?f=produto_detalhes\&pid=3430, acesso em 27 maio 2016.

${ }^{6} \mathrm{~A}$ tutoria oferece ao aluno um acompanhamento sistemático direcionando o estudo. Utilizase para isso métodos de ensino que estimulem o raciocínio. Dessa forma o aluno aos poucos conseguirá construir suas próprias definições e conjecturas sobre a matemática. Fonte: https://lemat.mat.ufg.br/p/7386-projetos-ativos, acesso em 27 maio 2016.

${ }^{7} \mathrm{~A}$ assessoria consiste no auxílio a instituições externas e a professores na construção, elaboração e realização de atividades relacionadas à matemática. Fonte: https://lemat.mat.ufg.br/p/7386projetos-ativosi, acesso em 27 maio 2016.
} 
Lorenzato (2006), buscando ampliar a concepção de Laboratório de Ensino de Matemática (LEM), afirma que este

[...]é um local da escola reservado preferencialmente não só para aulas regulares de matemática, mas também para tirar dúvidas de alunos; para os professores de matemática planejarem suas atividades, sejam elas aulas, exposições, olimpíadas, avaliações, entre outas, discutirem seus projetos, tendências e inovações; um local para criação e desenvolvimento de atividades experimentais, inclusive de produção de materiais instrucionais que possam facilitar o aprimoramento da prática pedagógica. (p.6). 39]

No LEMAT, aconteciam a maior parte das atividades associadas ao ensino, como por exemplo, apresentações de Trabalhos de Conclusão de Curso (TCCs), o curso de Especialização em Educação Matemática, atividades de tutoria, projetos em parceria com escolas públicas, orientações de estágio e docência, campeonatos de jogos matemáticos entre outras.

Me interessei pelas atividades desenvolvidas naquele espaço e passei a ser voluntária na organização desse laboratório de ensino, catalogando as bibliografias, construindo e organizando materiais didáticos e jogos.

Em 2007, tornei-me bolsista do projeto de extensão "XII Jornada de Educação Matemática" 8 desenvolvendo-o em parceria com o LEMAT. Esse projeto é realizado desde 1994, pelo IME/UFG. No evento há apresentação de palestras e oficinas dos principais pesquisadores da área no país e de professores da Educação Matemática das universidades federais, estaduais e particulares.

O contato com o LEMAT foi fundamental para a minha formação crítica, como professora de matemática. Possibilitou-me participar de várias oficinas, cursos, debates, fóruns e discussões que aconteciam naquele ambiente.

O LEMAT é o elo entre a Universidade e a escola, pois conta com a participação de professores e alunos de escolas públicas em suas oficinas, além de oferecer espaço aos estagiários e ofertar também o curso Especialização em Educação Matemática, curso do qual participei em 2011.

Por meio de suas atividades, o LEMAT estreita a relação entre alunos do curso de licenciatura, que serão futuros professores, e professores atuantes nas escolas públicas neste momento.

\footnotetext{
${ }^{8}$ Projeto financiado pelo Programa de Bolsas de Extensão e Cultura da UFG (PROBEC), com apoio da Sociedade Brasileira de Educação Matemática - Regional Goiás (Sbem-GO) e do Núcleo de Educação Matemática de Goiás (NuEM). Evento realizado no período de 07, 08 e 09 de maio de 2008.
} 
Entre essas atividades, aconteciam no LEMAT: o uso de origami, material dourado, malha quadriculada, "software", jogos e várias outras. Particularmente, os jogos me atraíam mais por perceber o quanto o aluno era envolvido pelo aspecto desafiador e lúdico, se afastando da realidade, chegando a criar uma nova realidade própria da ação de jogar. Kishimoto (1996 apud GRANDO, 2000), pontua que:

As crianças ficam mais motivadas a usar a inteligência, pois querem jogar bem; sendo assim, esforçam-se para superar obstáculos, tanto cognitivos quanto emocionais. Estando mais motivadas durante o jogo, ficam também mais ativas mentalmente. (p.27). 31]

As crianças sentiam-se motivadas a jogar e a conhecer a matemática, contida nos jogos e meta-jogos. Entendemos meta-jogo como as situações posteriores ao jogo, nas quais os estudantes preenchem registros e são questionados com o objetivo de entrelaçar o jogo e o conhecimento matemático (MORBACH, 2012).

Ao acompanhar o desenvolvimento desses trabalhos no LEMAT, especialmente com a utilização de jogos para o ensino de matemática, surgiu a oportunidade de me engajar como bolsista e pesquisadora no projeto "Jogos Estratégicos no Ensino de Matemática - Refletir, Implementar e Avaliar"’? no qual, sob orientação da professora doutora Maria Bethania Sardeiro dos Santos em parceria com o professor doutor Bryon Richard Hall, trabalhamos com os jogos: Nim, Hackenbush, Kayles, Domineering, Brotas e Hex.

Esse projeto iniciou-se com estudos e apresentações de seminários do professor Bryon Hall, de estudantes do curso de graduação em matemática do IME/UFG, contando com a participação de estudantes da Universidade Estadual de Goiás (UEG), como ouvintes.

\footnotetext{
${ }^{9}$ Projeto desenvolvido no período: agosto/2008 a julho/2009, financiando pelo Programa de Bolsas para os cursos de Licenciatura da Universidade Federal de Goiás (PROLICEN) e desenvolvido no IME/UFG. Relatório disponível em: http://projetos.extras.ufg.br/conpeex/2009/artigos/prolicen/prolicen.pdf. Acesso em 19 fevereiro 2016.
} 
Breve descrição dos jogos discutidos no projeto - Jogos Estratégicos no Ensino de Matemática - Refletir, Implementar e Avaliar.10

\begin{tabular}{|c|c|}
\hline Jogo & Descrição básica \\
\hline Nim & $\begin{array}{l}\text { Jogo proveniente da China e jogado na Europa desde o século } \\
\text { XVI, no qual os dois jogadores que disputam a partida retiram } \\
\text { peças do monte, pelo menos uma. Ganha o jogo quem remove } \\
\text { a última peça da mesa. }\end{array}$ \\
\hline Hackenbush & $\begin{array}{l}\text { Jogo derivado do Nim, disputado por dois jogadores que vão } \\
\text { retirando as peças, da cor que lhe pertence, até que um deles } \\
\text { fique sem peças para serem retiradas. Perde o jogo o primeiro } \\
\text { jogador a ficar sem peças da sua cor para retirar. }\end{array}$ \\
\hline Kayles & $\begin{array}{l}\text { Jogo disputado por dois jogadores, no qual pinos de boliche } \\
\text { aparecem inicialmente enfileirados um ao lado do outro. A } \\
\text { cada jogada, usa-se a bola de boliche para derrubar ou um } \\
\text { pino qualquer, ou dois pinos adjacentes quaisquer, quem der- } \\
\text { rubar o último pino vence. }\end{array}$ \\
\hline Domineering & $\begin{array}{l}\text { Criado por Göran Anderson, esse jogo também é conhecido } \\
\text { por Crosscram e Stop-Gate. Utiliza-se um tabuleiro quadri- } \\
\text { culado, geralmente } 6 x 6 \text {. Cada jogador tem uma coleção de } \\
\text { dominós (peças no formato } 1 \times 2 \text { ) que serão dispostas sobre o } \\
\text { tabuleiro durante o jogo. Um jogador coloca seus dominós } \\
\text { na vertical e o outro na horizontal. Perde o jogo o primeiro } \\
\text { jogador que não conseguir colocar uma peça no tabuleiro. }\end{array}$ \\
\hline Brotas & $\begin{array}{l}\text { Brotas (sprouts em inglês) foi inventado pelos matemáticos } \\
\text { John Horton Conway e Michael E. Peterson em Cambridge } \\
\text { University em 1967. Jogado por duas pessoas, é formado por } \\
\text { pontos sobre o papel, variando de } 1 \text { a n pontos, dependendo da } \\
\text { escolha dos jogadores. Os jogadores unem os pontos, porém, } \\
\text { sem traçar curvas sobre outra já feita. Perde o jogo o jogador } \\
\text { que não conseguir mais fazer ligações entre os pontos. }\end{array}$ \\
\hline Hex & $\begin{array}{l}\text { Jogo geralmente em formato de losango, subdivido em } \\
\text { hexágonos } 11 x 11 \text {. Cada um dos jogadores escolhe várias peças } \\
\text { da mesma cor e parte de uma aresta, colocando suas peças. } \\
\text { Tentam chegar à aresta oposta do losango, formando uma } \\
\text { fileira contínua contendo apenas peças de uma mesma cor. }\end{array}$ \\
\hline
\end{tabular}

Tabela 1.1: Jogos: Nim, Hackenbush, Kayles, Domineering, Brotas e Hex.

\footnotetext{
${ }^{10}$ Para saber mais acesse:

https://jogoseeducacao.mat.ufg.br/

http://docslide.com.br/documents/jogos-estrategicos.html

http://www.sapientia.pucsp.br/tde_arquivos/13/TDE-2005-11-09T14:46:16Z-

1537/Publico/Dissertacao_FONSECA_Rogerio_F.pdf

Acesso em 28 maio 2016.
} 
Três jogos foram escolhidos (Nim, Hex e Domineering) e desenvolvidos com alunos do $8^{\circ}$ ano do Ensino Fundamental de uma escola pública de Goiânia entre setembro/2008 a fevereiro/2009. Durante esse período, houve a realização de um minicampeonato de jogos estratégicos na escola e em um segundo momento no LEMAT.

Durante a aplicação dos jogos, observava dificuldades dos alunos com relação à matemática, pois algumas jogadas exigiam conhecimentos da disciplina e reelaboração de estratégias. Tais dificuldades eram superadas à medida que o professor fazia intervenções e questionava os alunos a respeito das possíveis soluções. Assim, os alunos conseguiam estabelecer relações entre a matemática e o jogo, reelaborando suas estratégias.

Embora haja desejo por parte dos professores de tornar a matemática mais próxima da realidade dos estudantes, superando o discurso de que essa ciência é complicada e difícil, pode-se acontecer um reforço no sentido contrário, dentro das próprias salas de aula, por meio de aulas mal planejadas, cheias de repetições e desmotivadoras, resultantes principalmente de falhas na formação do professor e da ausência ou insuficiência de diálogo entre professor, coordenação pedagógica e alunos, além da falta de reflexão, avaliação e pesquisa a respeito da própria prática pedagógica.

Após a realização dos jogos com os estudantes, e construção das informações e análise, houve a divulgação dos resultados na escola, por meio de um banner elaborado pela pesquisadora e orientadora. Os estudantes demonstraram satisfação ao serem notificados dos resultados dos jogos disputados, do ranking com as premiações e também ao verem suas fotos durante as atividades realizadas.

O trabalho, com a colaboração do estudante Paulo Martins Júnior ${ }^{11}$, culminou na elaboração e apresentação do mini-curso "Jogos Estratégicos no Ensino da Matemática" ${ }^{12}$, que incluiu a produção de tabuleiros e todo o material necessário à aplicação dos jogos, posteriormente, doados ao LEMAT/UFG.

Vivenciar toda essa experiência durante o curso de licenciatura em matemática transformou o meu processo de formação e permitiu-me ser atuante nesse processo. Mostrou-me o quanto a atividade de pesquisa é importante para a formação continuada do professor de matemática, principalmente para os que atuam em salas de aula, pois possibilita entrelaçar teoria e prática, propiciando constante reflexão a respeito do ensino da matemática e da própria prática pedagógica.

Uma realidade própria das licenciaturas é que os alunos comecem a trabalhar

\footnotetext{
${ }^{11}$ Estudante do curso de licenciatura em matemática do IME/UFG e bolsista da Pró-Reitoria de Assuntos da Comunidade Universitária da UFG (PROCOM).

${ }^{12}$ Minicurso apresentado no "VII Encontro de Educação Matemática", em 2009, na Universidade Estadual de Goiás - Unidade Cora Coralina, na cidade de Goiás. Participaram desta oficina professores da educação básica e alunos do curso de licenciatura em matemática.
} 
antes mesmo de concluírem o curso, e comigo não foi diferente. No início de 2009, atuei como professora na Educação de Adolescentes Jovens e Adultos, em turmas de Ensino Fundamental Anos Finais no colégio SESI ${ }^{13}$ e, em novembro desse mesmo ano, em um curso Pré-Universitário na Casa da Juventude 14 , ambos na cidade de Goiânia, Goiás.

A Casa da Juventude trabalha com uma proposta diferente com relação ao ensino, afinal, tínhamos eixos que aproximavam as disciplinas, além de uma grande preocupação com a formação social e integral do indivíduo. Para Tonet (2008), formar integralmente, significa formar

indivíduos capazes de pensar com lógica, de ter autonomia moral; indivíduos que se tornem cidadãos capazes de contribuir para as transformações sociais, culturais, científicas e tecnológicas que garantam a paz, o progresso, uma vida saudável e a preservação de nosso planeta. Portanto pessoas criativas, participativas e críticas. (p.6). [70]

Considero essa experiência na Casa da Juventude uma das principais para a minha construção como professora de matemática, pois permitiu-me perceber cada estudante como ser ativo no próprio processo de aprendizagem, bem como a relevância da interação entre professores e equipe pedagógica, e da interação entre professor e estudantes para um profícuo processo de ensino e aprendizagem.

Em dezembro de 2009, com a conclusão do curso de licenciatura em matemática, o sonho de tornar-me "oficialmente" professora foi concretizado, embora considere valiosíssimas as experiências vivenciadas anteriormente e durante o período de graduação. Os estágios no LEMAT e em escolas, projetos de pesquisa e extensão, atividades voltadas para a licenciatura, entre outras, me capacitaram, fazendo-me sentir apta a encarar os desafios de ensinar matemática.

Recém formada, trabalhei em uma escola particular e, pouco tempo depois, ingressei na rede pública de ensino, como professora da Escola Municipal Herbert José de Souza, no município de Goiânia. Esta escola era organizada no sistema de ciclos e eu era professora nas turmas do ciclo III - alunos com idades entre 13 a 15 anos, o que corresponderia a $8^{\circ}$ e $9^{\circ}$ anos.

Como professora dessas turmas, pude perceber grandes dificuldades com relação a aprendizagem de álgebra, pois, em vários momentos, recorríamos ao ensino dos conteúdos curriculares dos $6^{\circ}$ e $7^{\circ}$ anos para que fosse possível dar continuidade ao processo de ensino e aprendizagem de álgebra previstos para $8^{\circ}$ e $9^{\circ}$ anos. Os estudantes apresentavam várias dúvidas, tanto relacionadas à apropriação da linguagem algébrica, quanto aos conceitos de expressões, equações e funções.

\footnotetext{
${ }^{13}$ Site - SESI - http://www.sesigo.org.br/sesi/site/Home.do?v=h. Acesso em 22 fevereiro 2016.

${ }^{14}$ Site - Casa da Juventude- http://www.casadajuventude.org.br/. Acesso em 22 fevereiro 2016.
} 
Para Duval (2003), a teoria dos Registros de Representação Semiótica possibilita compreender que a Matemática, diferencia-se de outras áreas de conhecimento como Química, Biologia e Física por seu caráter abstrato, ou seja, não ser observável através de objetos concretos, sendo necessária, para sua apreensão, a utilização e articulação das representações semióticas. Esses registros de representação semióticas são definidos pelo autor como “... produções constituídas pelo emprego de signos pertencentes a um sistema de representações os quais têm suas dificuldades próprias de significado e funcionamento" (Duval, 1993, p.39).

Ensinar álgebra parecia ainda mais desafiador do que ensinar os demais conteúdos, era essa a impressão que trazíamos ao longo da experiência como docente em salas de aula do ensino fundamental. Afinal, a álgebra se constitui de uma linguagem própria e totalmente simbólica.

Nesse sentindo, Malta(2004 apud GIL 2008) aponta que:

Sem o desenvolvimento do domínio da linguagem necessária à apreensão de conceitos abstratos (e, portanto, extremamente dependentes da linguagem que os constrói) nos seus diversos níveis, não pode haver o desenvolvimento do pensamento matemático (também em seus diferentes níveis). (p.31). [28]

Contudo, consideramos fundamental o desenvolvimento dessas habilidades com os estudantes, para que os mesmos não sejam induzidos a simples manipulação, seguindo modelos em situações padronizadas e totalmente destituídas de significado. Em minhas experiências com turmas de $8^{\circ}$ e $9^{\circ}$ ano, em que geralmente houve contato contínuo com a álgebra, não era difícil notar que a principal dificuldade dos alunos estava em relacionar a linguagem natural (língua portuguesa) com a linguagem algébrica.

Carregada de inquietações e convicta da relevância da continuidade na formação do professor, decidi inscrever-me para a seleção do curso de Especialização em Educação Matemática do IME/UFG e fui aprovada, iniciando-o no ano de 2011.

Durante o curso de especialização, tive contato com o professor Wellington Lima Cedro, que desenvolvia o projeto "Clube de Matemática" 15, e estava interessado em trabalhar com professores da rede pública de ensino, que pudessem desenvolver o projeto Clube de Matemática com suas turmas nas escolas. Fiquei encantada com a proposta, pois era muito adequada ao perfil de alunos para o qual lecionava naquele momento e poderia se apresentar como uma das soluções para as problemáticas vivenciadas por mim e pelos meus alunos quanto ao ensino e aprendizagem de álgebra.

\footnotetext{
${ }^{15} \mathrm{O}$ Projeto Clube de Matemática desenvolvido pelo IME/UFG tem suas raízes no Clube de Matemática desenvolvido na Faculdade de Educação da Universidade de São Paulo (FE-USP) pelo professor Dr. Manoel Oriosvaldo de Moura. Disponível em: http://www2.fe.usp.br/ labmat/clube/home.html, acesso em 06/07/2016.
} 
Considerando o cenário nas turmas em que lecionava e por estar em contato com o Clube de Matemática, optamos por desenvolver o projeto Clube de Matemática $\sqrt{16}$ na instituição onde eu lecionava. Porém, conforme decisão tomada posteriormente, pelos membros do Clube de Matemática, a aplicação das atividades aconteceu em turmas de $6^{\circ}$ anos.

O nosso grupo de pesquisa do Clube de Matemática era composto por cinco profissionais ao todo: três cursistas da Especialização em Educação Matemática que também eram professores da rede pública de ensino da cidade de Goiânia; um colaborador, que era aluno do curso de licenciatura em matemática; o professor orientador. $\mathrm{O}$ objetivo principal do Clube de Matemática era "criar um ambiente para o desenvolvimento de atividades educativas que possibilitem a discussão dos mais variados aspectos dentro do meio educacional" (Cedro, 2004, p.52). [16].

Realizávamos encontros semanais para discutir as dificuldades relacionadas ao ensino de matemática, mais especificamente de álgebra, de metodologias, de ferramentas e de possibilidades de soluções para as falhas apresentadas no processo de ensino e aprendizagem.

Durante alguns meses, avaliamos, reestruturamos, adaptamos e, principalmente, criamos várias atividades de ensino que, hipeoteticamente, viriam a contribuir para o ensino e aprendizagem do conteúdo expressões algébricas. Conteúdo este, delimitado pelo grupo por meio da pesquisa e da reflexão a respeito da própria pratica pedagógica. As atividades de ensino propostas no Clube de Matemática, a forma como foram aplicadas e algumas produções que surgiram a partir desta experiência serão abordadas de forma mais detalhada nos próximos capítulos.

Após este período de três anos em Goiânia, por ter sido aprovada em um concurso, vim para a capital Brasília trabalhar como professora da rede pública de ensino do Distrito Federal, que é onde atuo há quatro anos como professora do Ensino Fundamental Anos Finais.

Como professora de matemática do Ensino Fundamental, percebo o relevante papel do professor no processo de formação dos estudantes, direcionando-os, segundo os seus objetivos. Esse processo não se resume a ensinar matemática a esses estudantes, mas, sobretudo, torná-la instrumento para formação integra ${ }^{17}$ desses indivíduos, permitindo-os serem atuantes, reflexivos e ativos no próprio processo de aprendizagem. O professor de matemática enfrenta vários desafios próprios da sua disciplina que, por sua vez, ainda carrega o estigma de ser complicada e difícil. Enfim, uma ciência que

\footnotetext{
${ }^{16}$ Experiência será relatada de forma detalhada nos próximos capítulos.

${ }^{17}$ Entendemos, por formação integral do indivíduo, a sua formação como um todo, tornando-o autor e ator no desenvolvimento e aprendizagem, preparando-o para a vida. Uma formação capaz de torná-lo crítico, investigativo, criativo, solidário e capaz de solucionar seus problemas.
} 
faz sentido apenas para um grupo restrito e supostamente superior intelectualmente.

Continuo vivenciando esses mesmos desafios, dificuldades e limitações próprias do processo de ensino e aprendizagem de matemática, o que me leva a observar que tais desafios, apesar de suas distinções, não se tratam de casos regionais. Afinal, há semelhanças entre os processos de aprendizagem de álgebra que, em sua maioria, estão diretamente ligadas a passagem do pensamento apenas aritmético para o desenvolvimento do pensamento algébrico.

Todos esses anos dedicados ao ensino de matemática trouxeram inquietações, experimentações, incertezas, validações e provocaram grandes mudanças na forma de perceber o ensino de matemática e na própria prática pedagógica.

Em busca de superação desses desafios, ou pelo menos de parte deles, e entendendo que as possibilidades de superação surgem a partir de pesquisas e diálogos entre aqueles que vivenciam desafios semelhantes e também por meio da formação continuada do professor, o que permite-lhe entrelaçar pesquisa e prática, senti-me estimulada a participar do Curso de Mestrado Profissional em Matemática em Rede Nacional (PROFMAT) ${ }^{18}$ oferecido pelo Departamento de Matemática da Universidade de Brasília (MAT/UNB). O curso PROFMAT

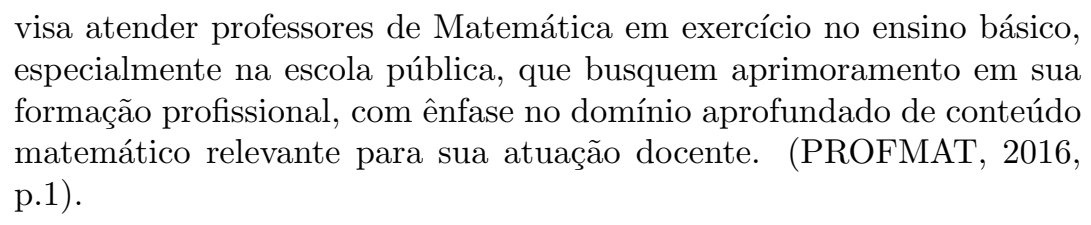

A minha turma iniciou o curso PROFMAT, em 2014, com 30 alunos, dos quais a grande maioria pertencia ao quadro de professores da Secretaria de Educação do Distrito Federal (SE-DF), ou seja, professores de matemática da Educação Básica. Em dois anos, cursamos 10 disciplinas, que nos permitiram aperfeiçoar nosso conhecimento sobre os conteúdos matemáticos.

Apesar da maior parte das disciplinas possuírem um viés estritamente matemátic ${ }^{19}$, em alguns momentos, haviam intervenções no sentido de relacionar os conteúdos às realidades vivenciadas por nós professores da Educação Básica. Demonstrávamos um interesse que ia além de conhecer o conteúdo matemático, desejávamos combiná-lo com a didática, a fim de atingirmos uma melhor compreensão a

\footnotetext{
${ }^{18}$ O Programa é coordenado pelo Conselho Gestor e pela Comissão Acadêmica Nacional, que operam sob a égide do Conselho Diretor da Sociedade Brasileira de Matemática, e é executado pelas Comissões Acadêmicas das Instituições Associadas. Disponível em: http://www.profmat-sbm.org.br/. Acesso em 29 maio 2016.

${ }^{19}$ Entendemos como disciplinas que reforçavam o conteúdo matemático já estudado durante a graduação, inclusive de forma mais aprofundada, porém, sem o elo com o ensino, desligadas da sua relação com o pedagógico ou o didático.
} 
respeito do processo de ensino e aprendizagem de matemática, tanto no próprio curso de pós-graduação, quanto na Educação Básica.

Uma das disciplinas marcantes foi Avaliação Educacional, lecionada pelo professor Mauro Luiz Rabelo, na qual tivemos a oportunidade de compreender melhor os processos avaliativos e como se dão as avaliações em larga escala 20 . As aulas dessa disciplina eram momentos de discussão sobre a avaliação dentro do contexto da Educação Básica. Estávamos em constante reflexão a respeito da própria prática pedagógica.

O livro texto da disciplina "Avaliação Educacional: fundamentos, metodologia e aplicações no contexto brasileiro" "21], cujo autor é o próprio professor Rabelo, propõe uma excelente metodologia de construção de itens, ensinando a nós professores como elaborar itens com maior qualidade e que atendam os nossos objetivos ao avaliar.

À medida que cursávamos as disciplinas, pude perceber como a dificuldade de apropriação da linguagem matemática se apresentava como barreira para a aprendizagem dos conteúdos. A disciplina Fundamentos de Cálculo foi classificada como uma das mais difíceis pela turma, justamente por sua característica de rigor e formalismo nas demonstrações e escrita próprios da Análise Rea 22 .

Mais uma vez observava o estreitamento da relação entre as dificuldades dos alunos da Educação Básica e as dificuldades enfrentadas por nós, professores da Educação Básica, enquanto alunos de um curso de pós graduação em matemática. Essas dificuldades na apropriação dos conceitos matemáticos, especialmente algébricos, podem ser refletidas em nossas salas de aula e interferir na aprendizagem do grupo para o qual ensinamos.

Ribeiro(2015) discute as dificuldades de professores e alunos da Educação Básica quanto à compreensão do conceito de função apresentando várias pesquisas que reforçam essa ideia de que as dificuldades dos estudantes também estão associadas às dificuldades enfrentadas por seus professores.

Nós professores, assim como nossos alunos, estamos em constante processo de formação e de aprendizagem, sujeitos às oscilações e metamorfose. Considerando toda a minha trajetória de aprendizagem e ensino de matemática, ora como estudante nos cur-

\footnotetext{
${ }^{20}$ Avaliações aplicadas de forma padronizada para um grande número de pessoas. Para saber mais: http://simposio.profmat-sbm.org.br/docs/Mesa-redonda-MauroRabelo.pdf, acesso em 30 maio 2016.

${ }^{21}$ Este livro aborda concepções e finalidades das avaliações educacionais de larga escala, passa pelos fundamentos da teoria de resposta ao item, atinge o ápice com a metodologia de construção de itens e chega à reflexão sobre avaliação como meio para regular a aprendizagem dos estudantes. Fonte: http://loja.sbm.org.br/index.php/colecao-profmat/avaliac-o-educacional-fundamentosmetodologia-e-aplicacoes-no-contexto-brasileiro.html. Acesso em 30 maio 2016.

${ }^{22}$ Em cursos de cálculo, algumas ideias são apresentadas de modo intuitivo e informal. Historicamente, foi desse modo, intuitivo e informal, que certos conceitos foram criados. Entretanto, alguns avanços na teoria passaram a exigir maior precisão e rigor para que certas questões fossem esclarecidas, o que aconteceu de modo gradual a partir de 1820. A esse estudo mais rigoroso e profundo dos números e suas funções damos o nome de Análise Real. (MONTEIRO,2014.) [45].
} 
sos de graduação e pós graduação, ora como professora, percebo que muitas inquietações e curiosidades foram respondidas. No entanto, outras proliferam ou reinventam-se. Por isso, há a necessidade contínua de pesquisa e de associação desta à prática pedagógica. Assim, percebo no desenvolvimento deste trabalho, mais uma oportunidade de construção humana e profissional, propiciada pelo ensino de matemática. 


\section{Capítulo 2}

\section{A álgebra na Educação Básica}

\subsection{A construção histórica do ensino de álgebra}

Durante o século XIX, a álgebra era a parte da matemática que se dedicava principalmente à resolução de equações. Eves(2004) afirma que egípcios e babilônios deram início às atividades algébricas, que mais tarde foram desenvolvidas pelos gregos, que demonstravam preocupação em provar suas generalizações. Os gregos dedicaramse, principalmente, à álgebra geométricd estudavam as figuras geométricas e generalizações de suas propriedades.

Ainda segundo Eves(2004), os hindus e árabes, com base nos trabalhos desenvolvidos por egípcios e babilônios, encontraram soluções para equações, sendo essas últimas ainda mais complexas que as até então desenvolvidas.

Na busca por solução de equações, os árabes se referiam ao valor desconhecido como "coisa", que, em árabe, era uma palavra pronunciada como xay. Por isso, usamos o x, que é considerado uma tradução simplificada da palavra "coisa", escrita em árabe.

Em 1931, com a Reforma Francisco Campos, as disciplinas de geometria, álgebra e aritmética foram unificadas, instituindo assim a palavra "Matemática". Ou seja, quase dois séculos de produções acerca da matemática.

Na década de 60, sob as influências do movimento internacional conhecido como Matemática Moderna, ocorreram mudanças expressivas na forma como era concebido o ensino de Matemática no Brasil. Esse movimento pretendia modernizar o ensino nessa área, tanto para atender exigências de uma sociedade que avançava tecnologicamente, quanto para adequar às necessidades da indústria, que se encontrava em expansão e, por sua vez, orientava a reconstrução no Pós-Guerra.

${ }^{1}$ A algébra geométrica trabalha com a ideia de representar elementos algébricos por meio de elementos geométricos e objetos geométricos e por meio de objetos algébricos. Para saber mais, acesse: http://www.ime.unicamp.br/ vaz/algeo.htm. Acesso em 26 maio 2016. 
Em julho de 1962, em Belém do Pará, foi realizado O IV Congresso Brasileiro do Ensino da Matemática, que, pela primeira vez, tratou do problema da introdução da Matemática Moderna no Ensino Secundáric2. Esse movimento mobilizou de maneira tão expressiva a comunidade de professores e pesquisadores do ensino da Matemática que, inciou-se uma nova etapa no processo de organização curricular da Matemática escolar, além da alavancar a produção de materiais destinados a professores.

Entre as décadas de 1970 e 1990, quando buscava-se pesquisas relacionadas ao ensino de álgebra, percebeu-se o descaso com essa área. Miguel, Fiorentini e Miorim (1992) denunciam esse "abandono" da álgebra e reforçam que não trata-se, necessariamente, de falta de informação, mas de um ensino por meio do qual os estudantes apenas repetem os procedimentos aprendidos, as manipulações algébricas, e não compreendem os significados. Apontam, a necessidade de renovação desse ensino, de forma a imprimir novas significações e direções.

As pesquisas na área de Educação Matemática, bem como as diretamente relacionadas ao ensino de álgebra, desenvolvem-se tanto nos programas de educação e espaços de formação de professores, quanto nos programas de pós-graduação. Os trabalhos advindos dessas investigações acadêmicas que circulam em revistas especializadas e as publicações científicas da Educação Matemática têm crescido significativamente nos últimos anos. A Educação Matemática também se organiza em sociedades locais, nacionais, regionais e internacionais que promovem eventos como seminários, conferências e congressos.

Considerando as publicações relacionadas ao ensino e aprendizagem de matemática, notamos que, de maneira geral, nas últimas décadas, o processo de ensino e aprendizagem de álgebra tem sido objeto de análise e discussão na literatura em Educação Matemática, bem como tornando-se tema importante nos principais eventos que tratam do Ensino de Matemática.

Desse modo, escolhemos os dois principais eventos nacionais, relacionados ao Ensino de Matemática, realizados pela da Sociedade Brasileira de Educação Matemática $3^{3}$ (SBEM), para fazer um levantamento dos temas abordados e discutidos nos trabalhos que compõem esses eventos.

A SBEM foi criada em 27 de janeiro de 1988 e é uma sociedade civil, de caráter científico e cultural, sem fins lucrativos e sem qualquer vínculo político, partidário ou religioso. Atualmente, congrega profissionais da área de Educação Matemática e de áreas afins e tem em seus quadros pesquisadores, professores e alunos que atuam nos

\footnotetext{
${ }^{2} \mathrm{O}$ Ensino Secundário corresponde ao atual segundo segmento do Ensino Fundamental (Lei $9.394 / 96)$

${ }^{3}$ Para saber mais acesse o site da SBEM: http://www.sbembrasil.org.br/sbembrasil/. Acesso em 04 junho 2016.
} 
diferentes segmentos e níveis do sistema educacional brasileiro, desde a educação básica à superior, além de sócios institucionais e sócios de outros países.

A SBEM tem como missão encontrar meios para desenvolver a formação matemática de todo cidadão brasileiro. Por meio do estímulo às várias atividades de pesquisa e de estudos acadêmicos, a SBEM promove o desenvolvimento da matemática e educação matemática, além de difundir as informações e conhecimentos nas vertentes da Educação Matemática.

Os eventos escolhidos, ambos organizados e realizados pela SBEM com o apoio de outros grupos e universidades, foram o XI Encontro Nacional de Educação Matemática $4^{4}$ (XI ENEM) e VI Seminário Internacional de Pesquisa em Educação Matemátict5(VI SIPEM).

O primeiro Encontro Nacional de Educação Matemática (ENEM) foi realizado pela primeira vez em 1987, na PUC-SP. Surgindo a partir da necessidade de promoção de debates e de discussões entre diversos grupos: de professores, de estudantes e de pesquisadores no país, que visavam melhorias e um futuro promissor no espaço que lhes cabia no campo educativo. Atualmente o ENEM é realizado trianualmente e é o evento de maior importância no âmbito nacional.

O SIPEM surgiu como uma proposta de aprimoramento dos ENEMs, que, devido à grande diversidade de seu público, não proporcionava maior intercâmbio entre os pesquisadores brasileiros e de outros países. Nesse sentido, o SIPEM promove o diálogo entre esses pesquisadores, possibilitando avaliar e divulgar as produções brasileiras em termos internacionais, além de formar parcerias em projetos com grupos de estudos e pesquisas nacionais e internacionais.

O SIPEM teve o seu primeiro encontro realizado em novembro de 2000. E em novembro de 2015, na cidade de Pirenópolis-Goiás, aconteceu o VI SIPEM, sendo este o mais recente entre os eventos mais importantes no campo da Educação Matemática. Esse Seminário tem como objetivo promover o intercâmbio entre grupos do Brasil e de diferentes países que se dedicam às pesquisas em Educação Matemática. Dessa forma, as pesquisas brasileiras são divulgadas e há a possibilidade do encontro entre os pesquisadores que as promovem, proporcionando-lhes conhecer investigações que estão sendo realizadas em diferentes instituições nacionais e internacionais.

A partir desses dois eventos, foi possível observar que a preocupação com o ensino e aprendizagem de álgebra é tema recorrente na comunidade de educadores matemáticos. Os conteúdos algébricos e o ensino desses conteúdos foram abordados

\footnotetext{
${ }^{4}$ Para saber mais acesse o site do XI ENEM: http://enem2013.pucpr.br/. Acesso em 04 junho 2016.

${ }^{5}$ Para saber mais acesse o site do VI SIPEM: http://www.sbembrasil.org.br/visipem/index.html. Acesso em 04 junho 2016.
} 
em vários trabalhos apresentados no ENEM e no SIPEM, que são considerados os eventos mais importantes no âmbito nacional. Alguns desses textos ${ }^{6}$ tornaram-se referência para o presente trabalho, entre eles: os estudos de Martins(2013), que faz um diagnóstico dos aspectos que dificultam a passagem da aritmética para a álgebra na educação básica brasileira e de Oliveira(2013), que traz as atividades lúdicas usadas para o ensino de álgebra no clube de matemática.

Ao todo, encontramos 51 trabalhoł7 relacionados à Álgebra. A seguir apresentamos uma classificação criada com base nas propostas contidas nos trabalhos publicados a partir desses dois eventos.

\section{Classificação dos trabalhos relacionados à Álgebra}

\begin{tabular}{l|l}
\hline Direcionamento & Quantidade \\
\hline $\begin{array}{l}\text { Discussão e proposição de atividades acerca do ensino de } \\
\text { álgebra }\end{array}$ & 07 \\
\hline Análise do livro didático & 04 \\
\hline $\begin{array}{l}\text { Análise do currículo e outros documentos relacionados ao en- } \\
\text { sino; exclusivamente de cunho bibliográfico }\end{array}$ & 05 \\
\hline Formação de professores & 07 \\
\hline Formação continuada de professores & 02 \\
\hline Aprendizagem de álgebra - Educação Especial & 01 \\
\hline Aprendizagem de álgebra - Ensino Fundamental Anos Iniciais & 03 \\
\hline Aprendizagem de álgebra - Ensino Fundamental Anos Finais & 15 \\
\hline Aprendizagem de álgebra - Ensino Médio & 04 \\
\hline Aprendizagem de álgebra - Ensino Superior & 03 \\
\hline
\end{tabular}

Tabela 2.1: Pesquisas em Álgebra

Por meio desse levantamento, pudemos notar uma preocupação a respeito da forma com que a álgebra é ensinada, atualmente, em todas as fases do ensino. Percebemos que vários pesquisadores apontam novas metodologias e ferramentas para o ensino dos conteúdos algébricos, propondo, de certa forma, um rompimento com o ensino tradicional, no qual a álgebra é vista apenas como um instrumento na solução de equações.

As pesquisas observadas propõem o uso de situações problema, de generalizações, da construção de oficinas e de materiais, uso de softwares, ou seja, meios que proporcionam ao estudante ser ativo no processo de aprendizagem, criar, propor e validar suas hipóteses, construindo, sob orientação do professor, os próprios conceitos

\footnotetext{
${ }^{6}$ Disponível em: http://sbem.web1471.kinghost.net/anais/XIENEM/trabalhos_1.html. Acesso em 05 junho 2016.

${ }^{7}$ Os trabalhos citados a seguir, estão disponíveis no site da SBEM e também nos respectivos sites dos eventos XI ENEM e VI SIPEM. Site: http://www.sbembrasil.org.br/sbembrasil/index.php/anais. Acesso em 05 junho 2016.
} 
algébricos.

Nesse sentido, Ribeiro (2015) [55] aponta que são necessárias pesquisas com foco nas concepções dos professores que ensinam matemática na Educação Básica e na produção dos estudantes. Todavia, é necessário reconhecer que há uma falha na divulgação dessas pesquisas que já foram feitas.

Muitas vezes esses trabalhos não são levados aos debates e planejamentos escolares para que sejam discutidos os seus resultados. Logo, o acesso a essas informações, análises e diálogos ficam restritos aos professores que estão em contato direto com as universidades, cursos de formação continuada e que participam de eventos nos quais há apresentações de trabalhos e debates sobre os temas relacionados.

Consequentemente, há um grande desafio: fazer com que as produções relacionadas ao ensino e aprendizagem de matemática, cheguem até os professores da Educação Básica e sejam incorporadas às suas ações pedagógicas, provocando constante reflexão e discussão à respeito do ensino, qualificando suas práticas docentes.

É válido destacar que os professores precisam ter acesso não somente às pesquisas relacionadas ao ensino, mas também às que são feitas com a participação dos alunos, que buscam compreender a forma como os estudantes estão pensando e assimilando a matemática.

Os resultados das avaliações em larga escala muitas vezes não são discutidos e aproveitados pela maioria dos professores. Tais avaliações, devido às influências da mídia e da falta de conhecimento e propostas por parte das direções e coordenações escolares, têm sido entendidas, pelos pais de alunos e até mesmo no âmbito escolar como classificatórias e não como mais uma ferramenta no diagnóstico do processo de ensino e aprendizagem. Para Marinho-Araujo e Rabelo (2015),

A avaliação é um processo amplo, complexo, que ultrapassa sobrema-
neira o nível do indivíduo, com desdobramentos coletivos e institucio-
nais. Com características e finalidades educativas e pedagógicas, o pro-
cesso vai muito além do estabelecimento de indicadores de classificação
meritocrática de estudantes, cursos e instituições, devendo ocupar-se
da investigação acerca da formação humana e da construção da cida-
dania, considerando questões subjetivas e contextuais. O processo de
avaliação deve ter caráter formativo e de desenvolvimento, de modo a
influenciar a reconfiguração de contextos, condições sociais e propostas
pedagógicas, para que esses se constituam em opções mais favoráveis à
construção das competências necessárias ao perfil que se deseja formar.
(p. 443). 43.

Considerando a importância do processo avaliativo e das pesquisas que discutem o processo de ensino e aprendizagem de matemática, mais especificamente álgebra, uma vez que nos oferecem, de maneira geral, um "feedback" da aprendizagem a partir 
da participação dos estudantes e investigações, propomos a seguir, a utilização da catalogação, construída por Ribeiro (2015), que revela algumas modalidades de trabalhos científicos que investigam os erros e dificuldades de aprendizagem em matemática.

1. Análise de erros, discutindo-os à luz de alguma teoria;

2. Análises de produção e escrita - buscam entender como os estudantes lidam com os problemas, seja por meio das respostas corretas ou incorretas;

3. Investigações - detectam erros e dificuldades dos estudantes e criam estratégias que auxiliam na aprendizagem dos conceitos;

4. Análises de erros nos quais os autores partem dos próprios erros e levam os estudantes a reescreverem suas respostas, orientando-os nas diversas fases de reescrita ou criando novas metodologias didáticas.

Todos estes trabalhos demonstram uma preocupação em se discutir e alavancar o processo de aprendizagem em matemática, pois não se trata apenas da identificação dos erros. Afinal, identificá-los é uma tarefa simples. Trata-se da análise destes erros, uma incumbência que somente os professores têm condições de fazer, discutindo-os e opinando a respeito das possibilidades de origem, bem como aproveitando-os de forma que venha contribuir para a reflexão do estudante e para a aprendizagem.

\subsection{A matemática e a álgebra nas avaliações nacio- nais e internacionais}

Os índices de aproveitamento em matemática ainda são muito baixos, não só no Brasil, mas em vários países, tornando essa preocupação com o ensino e aprendizagem de matemática uma questão mundialmente discutida.

O Programme for International Student Assessment, em português, Programa Internacional de Avaliação de Estudantes 8 (PISA), é o programa que avalia o desempenho de estudantes, na faixa de 15 anos de idade, em três áreas: leitura, matemática e ciências. Essas avaliações acontecem a cada três anos e, em 2003 e 2012, teve como foco a Matemática.

O PISA é desenvolvido e coordenado pela Organização para Cooperação e Desenvolvimento Econômico (OCDE). Contudo, cada país participante possui coordenação própria, que, no Brasil, é realizada pelo Instituto Nacional de Estudos e Pesquisas Educacionais Anísio Teixeira (Inep). O Brasil é o único país sul-americano que participa do PISA desde sua primeira aplicação em 1998. O objetivo do PISA é

\footnotetext{
${ }^{8}$ Para saber mais, acesse: http://portal.inep.gov.br/pisa/sobre-o-pisa. Acesso em 06 junho 2016.
} 
produzir indicadores que contribuam para a discussão da qualidade da educação nos países participantes, de modo a subsidiar políticas de melhoria do ensino básico. A avaliação procura verificar até que ponto as escolas de cada país participante estão preparando seus jovens para exercer o papel de cidadãos na sociedade contemporânea. (INEP,2011). 33

Além de avaliar as competências dos estudantes nas três áreas já citadas, o PISA, por meio da aplicação de questionários e coleta de informações, indicadores contextuais e que possibilitam relacionar o desempenho dos alunos a variáveis demográficas, socioeconômicas e educacionais.

O nível de dificuldade de cada item da prova permite estabelecer níveis de proficiência da área de matemática. Esses níveis compõe uma escalą ${ }^{9}$ de proficiência, proposta pelo PISA, dividida em seis níveis, nos quais estão descritas as habilidades esperadas dos estudantes que se enquadram naquele determinado nível.

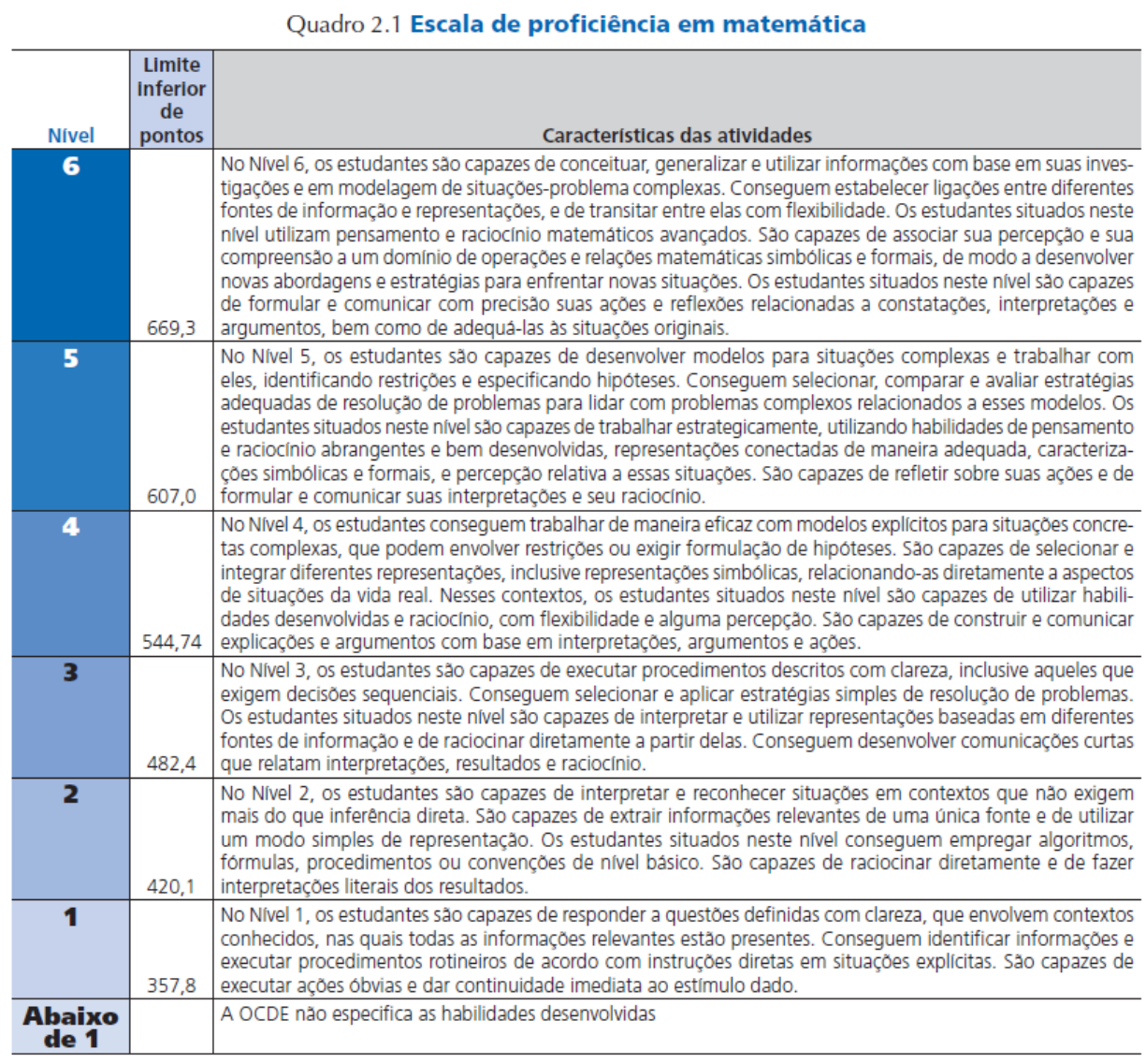

Figura 2.1: Escala proficiência em Matemática - PISA 2012 (INEP,2012).

\footnotetext{
${ }^{9}$ Para saber mais sobre a avaliação do PISA e conhecer todos os seus resultados em 2012, acesse o site do INEP ou o relatório da OCDE, disponível em: http://download.inep.gov.br/acoes_internacionais/pisa/resultados/2013/country_note_brazil_pisa_2012.pdf, acesso em 06 junho 2016.
} 
O gráfico a seguir mostra as médias de alguns países que realizaram o PISA. É importante associar essas médias aos níveis propostos pela escala do PISA na tentativa de compreender as possíveis habilidades dos estudantes de cada país.

\begin{tabular}{|c|c|c|c|c|c|c|c|c|c|c|}
\hline & \multicolumn{2}{|c|}{ PISA 2003} & \multicolumn{2}{|c|}{ PISA 2006} & \multicolumn{2}{|c|}{ PISA 2009} & \multicolumn{2}{|c|}{ PISA 2012} & \multicolumn{2}{|c|}{$\begin{array}{c}\text { Diferença entre } \\
2003 \text { e } 2012 \\
\end{array}$} \\
\hline & Média & EP & Média & EP & Média & EP & Média & EP & Média & EP \\
\hline Brasil & 356,0 & 4,8 & 369,5 & 2,9 & 385,8 & 2,4 & 391,5 & 2,1 & 35,4 & 5,4 \\
\hline México & 385,2 & 3,6 & 405,7 & 2,9 & 418,5 & 1,8 & 413,3 & 1,4 & 28,1 & 4,1 \\
\hline Portugal & 466,0 & 3,4 & 466,2 & 3,1 & 486,9 & 2,9 & 487,1 & 3,8 & 21,0 & 5,3 \\
\hline Coreia do Sul & 542,2 & 3,2 & 547,5 & 3,8 & 546,2 & 4,0 & 553,8 & 4,6 & 11,5 & 5,8 \\
\hline Espanha & 485,1 & 2,4 & 480,0 & 2,3 & 483,5 & 2,1 & 484,3 & 1,9 & $-0,8$ & 3,4 \\
\hline EUA & 482,9 & 2,9 & 474,4 & 4,0 & 487,4 & 3,6 & 481,4 & 3,6 & $-1,5$ & 4,9 \\
\hline Uruguai & 422,2 & 3,3 & 426,8 & 2,6 & 426,7 & 2,6 & 409,3 & 2,8 & $-12,9$ & 4,5 \\
\hline Finlândia & 544,3 & 1,9 & 548,4 & 2,3 & 540,5 & 2,2 & 518,8 & 1,9 & $-25,5$ & 3,0 \\
\hline Argentina & - & - & 381,3 & 6,2 & 388,1 & 4,1 & 388,4 & 3,5 & - & - \\
\hline Peru & - & - & - & - & 365,1 & 4,0 & 368,1 & 3,7 & - & - \\
\hline Colômbia & - & - & 370,0 & 3,8 & 380,8 & 3,2 & 376,5 & 2,9 & - & - \\
\hline Chile & - & - & 411,4 & 4,6 & 421,1 & 3,1 & 422,6 & 3,1 & - & - \\
\hline
\end{tabular}

Figura 2.2: Resultados do PISA para matemática em alguns países (INEP, 2012, p.15).

Observando o ano de 2012, é possível notar que entre os países citados, apenas Portugal, Espanha e Finlândia conseguiram médias capazes de alcançar a pontuação para classificação no nível 3, e somente a Coréia do Sul atingiu nível 4, de acordo com a escala de proficiência em matemática do PISA.

O Brasil, em 2003, apresentou média igual a 356,0, e em 2012, igual a 391,5. Foi o país em que houve o maior aumento na média, com uma diferença de 35,4 pontos a mais em 2012. Apesar desse aumento significativo, a média brasileira permanece associada ao nível 1.

O nível 1, segundo a escala de proficiência em matemática do PISA, demonstra que "os estudantes são capazes de responder a questões definidas com clareza, que envolvem contextos conhecidos, nas quais todas as informações relevantes estão presentes. Conseguem identificar informações e executar procedimentos rotineiros de acordo com instruções diretas em situações explícitas. São capazes de executar ações óbvias e dar continuidade imediata ao estímulo dado" (INEP, 2012, p.19).

A média Brasileira ainda se encontra abaixo da média dos estudantes da OCDE, que em 2012 foi igual a 498,0 pontos, ou seja, uma diferença de 106,5 pontos. Esses índices revelam que ainda há muitas dificuldades relacionadas a aprendizagem e a apropriação dos conceitos matemáticos que precisam ser superadas, para que o estudante consiga associar os conteúdos aprendidos na escola ao contexto vivenciado no dia a dia. 
A seguir, o gráfico mostra a distribuição percentual dos estudantes brasileiros nos níveis de proficiência em matemática nas edições do PISA de 2003 e 2012.

\section{Distribuição percentual dos estudantes nos níveis de proficiência em matemática nas edições do PISA de 2003 e 2012}

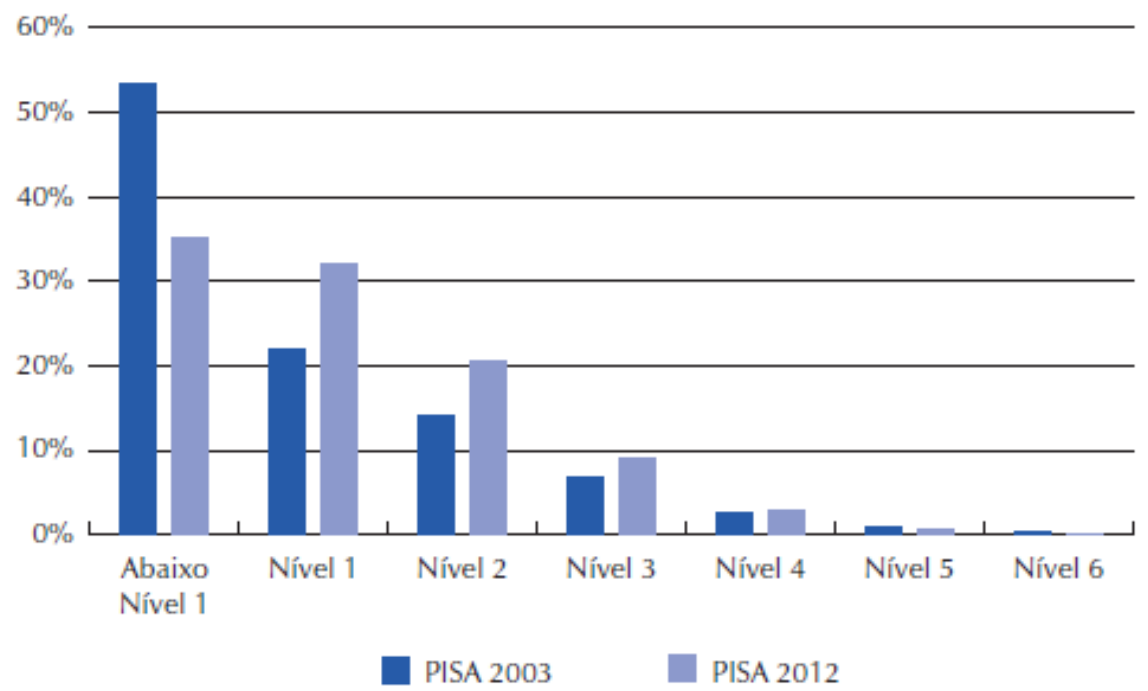

Figura 2.3: Distribuição dos estudantes brasileiros nos níveis de proficiência do PISA 2013 e 2012 (INEP, 2012, p.21).

Observamos que em 2012 houve uma melhora nos índices, uma vez que diminuiu o percentual de estudantes classificados abaixo do nível 1. No entanto, mais de $60 \%$ dos estudantes brasileiros ainda se encontram classificados abaixo ou no nível 1.

É importante ressaltar que esses resultados devem ser investigados para além dos números, das tabelas e dos gráficos. Afinal, esses índices sofrem influências de outros fatores, que ultrapassam as questões aplicadas e são relevantes ao discutir-se o quadro da educação brasileira.

Os resultados do PISA mostram que os estudantes, mesmo depois de permanecerem na escola por anos, uma vez que são estudantes com média de idade igual a 15 anos, que estariam em fase de conclusão do Ensino Fundamental Anos Finais, são classificados como mal alfabetizados matematicamente. Esses resultados indicam que, de modo geral, os estudantes são capazes apenas de ler os problemas propostos e resolver utilizando algoritmos apenas nos casos em que as informações são colocadas claramente para resolução.

Mais uma vez, ressaltamos a necessidade de reação do sistema educacional brasileiro no que se diz respeito à formação crítica dos cidadãos, que atuam e atuarão de forma ainda mais acentuada no mundo contemporâneo.

No âmbito nacional, o INEP, através do Sistema de Avaliação da Educação Básica (SAEB), também realiza outras importantes avaliações. O SAEB, além de 
contribuir para o acesso à escola, fornece informações importantes para a melhoria da qualidade da educação, que são fundamentais para a formulação, reformulação e o monitoramento das políticas públicas brasileiras voltadas para essa área.

O SAEB é composto por três avaliações externas em larga escala (as informações a seguir foram retiradas da página do SAEB) ${ }^{10}$.

\begin{tabular}{|c|c|}
\hline Avaliação & Descrição \\
\hline $\begin{array}{l}\text { Avaliaçao Nacio- } \\
\text { nal da Educação } \\
\text { Básica - Aneb }\end{array}$ & $\begin{array}{l}\text { abrange, de maneira amostral, alunos das redes públicas e } \\
\text { privadas do país, em áreas urbanas e rurais, matriculados na } \\
4^{\mathrm{a}} \text { série } / 5^{\circ} \text { ano e } 8^{\mathrm{a}} \text { série } / 9^{\circ} \text { ano do Ensino Fundamental e no } 3^{\circ} \\
\text { ano do Ensino Médio, tendo como principal objetivo avaliar } \\
\text { a qualidade, a equidade e a eficiência da educação brasileira. } \\
\text { Apresenta os resultados do país como um todo, das regiões } \\
\text { geográficas e das unidades da federação. }\end{array}$ \\
\hline $\begin{array}{l}\text { Avaliação Naci- } \\
\text { onal do Rendi- } \\
\text { mento Escolar - } \\
\text { Anresc (também } \\
\text { denominada } \\
\text { "Prova Brasil") }\end{array}$ & $\begin{array}{l}\text { trata-se de uma avaliação censitária envolvendo os alunos da } \\
4^{\mathrm{a}} \text { série } / 5^{\circ} \text { ano e } 8^{\mathrm{a}} \text { série } / 9^{\circ} \text { ano do Ensino Fundamental das } \\
\text { escolas públicas das redes municipais, estaduais e federal, com } \\
\text { o objetivo de avaliar a qualidade do ensino ministrado nas } \\
\text { escolas públicas. Participam desta avaliação as escolas que } \\
\text { possuem, no mínimo, } 20 \text { alunos matriculados nas séries/anos } \\
\text { avaliados, sendo os resultados disponibilizados por escola e } \\
\text { por ente federativo. }\end{array}$ \\
\hline $\begin{array}{l}\text { A Avaliação Na- } \\
\text { cional da Alfabe- } \\
\text { tização - ANA }\end{array}$ & $\begin{array}{l}\text { avaliação censitária envolvendo os alunos do } 3^{\circ} \text { ano do Ensino } \\
\text { Fundamental das escolas públicas, com o objetivo principal } \\
\text { de avaliar os níveis de alfabetização e letramento em Língua } \\
\text { Portuguesa, alfabetização Matemática e condições de oferta } \\
\text { do Ciclo de Alfabetização das redes públicas. A ANA foi } \\
\text { incorporada ao Saeb pela Portaria } n^{\circ} 482 \text {, de } 7 \text { de junho de } \\
2013 \text {. }\end{array}$ \\
\hline
\end{tabular}

Tabela 2.2: Avaliações realizadas pelo SAEB

A Prova Brasil, cujo objetivo é avaliar a qualidade do ensino em escolas das redes públicas, traz os resultados no formato de boletins, que ficam disponíveis on-line, além de fornecer também outras informações do contexto escolar, que estão associadas ao ensino, e as médias de desempenho das escolas com características próximas a da escola avaliada.

Esses dados, além de serem utilizados para nortear o planejamento pedagógico de cada escola, servem para a reflexão e planejamento de políticas públicas e ações que visam melhorar a qualidade da Educação Básica.

O professor, ao analisar esses resultados, tem condições de perceber quais competências foram e estão sendo construídas com os estudantes, podendo planejar e ori-

\footnotetext{
${ }^{10}$ As informações contidas na tabela, foram retiradas integralmente da página do SAEB http://portal.inep.gov.br/web/saeb/aneb-e-anresc. Acesso em 08 junho 2016.
} 
entá-los de maneira mais adequada. Ademais, o docente pode refletir sobre o contexto de sua disciplina na própria escola e sua prática de sala de aula.

A Prova Brasil, em matemática, propõe vários itens na forma de problemas, a fim de incentivar a utilização dessas situações-problema como mais uma ferramenta para a aprendizagem. A resolução de tais problemas permite ao estudante observar, estabelecer relações, comunicar-se utilizando diferentes linguagens, argumentar e validar ideias, além de estimular o raciocínio e desenvolver os processos intuitivos, de dedução e de estimativa.

A seguir, vamos mostrar um exemplo de item em matemática, utilizado na Prova Brasil para o $5^{\circ}$ ano do Ensino Fundamental.

O piso de uma sala está sendo coberto por cerâmica quadrada. Já foram colocadas 7 cerâmicas, como mostrado na figura.

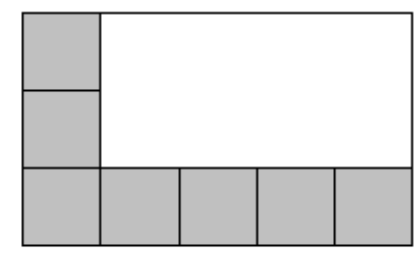

\section{Quantas cerâmicas faltam para cobrir o piso?}
(A) 7
(B) 8
(C) 9
(D) 15

Gabarito: (B)

Figura 2.4: Item de matemática - Prova Brasil (IT_025075)

O estudante pode resolver este item utilizando o conceito de área, ou ainda, atentar-se para um determinado padrão geométrico, para que consiga descobrir quantas cerâmicas faltam para que o piso seja coberto.

Ressaltamos, novamente, a importância da intencionalidade do professor, que pode utilizar os itens em suas salas de aula, explorando-os de forma conveniente e adaptando-os para atingir os objetivos pretendidos. Nesse item, IT_025075, por exemplo, o educador pode direcionar os estudantes para que estes encontrem meios de representar a quantidade de cerâmicas que ainda faltam para cobrir o piso, construindo os primeiros princípios da formalização da escrita algébrica.

O próximo item envolve diretamente a observação e a determinação do padrão 
utilizado para construir as figuras. É um item retirado da Prova Brasil de matemática, aplicada para estudantes do $9^{\circ}$ ano do ensino fundamental.

As figuras mostradas a seguir estão organizadas dentro de um padrão que se repete.

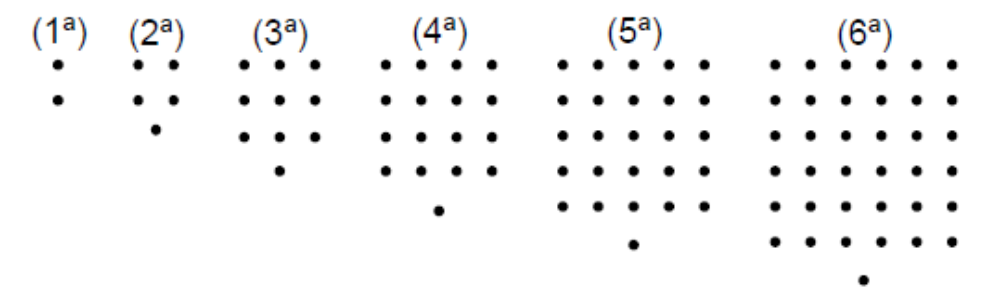

Mantendo essa disposição, a expressão algébrica que representa $\circ$ total de pontos $T$ em função da ordem $n(n=1,2,3, \ldots)$, é
(A) $T=2 n-1$.
(B) $T=2 n+1$.
(C) $T=n^{2}-1$.
(D) $T=n^{2}+1$.

Gabarito: (D)

Figura 2.5: Item de matemática - Prova Brasil (IT_021185)

Esse exemplo utiliza o processo de construção e de generalização de padrões, um dos princípios algébricos. Segundo as recomendações dos Parâmetros Curriculares Nacionai $\underbrace{11}$ (PCNs), é importante partir das generalizações para que, posteriormente possa-se formalizar, validando os conceitos algébricos. O estudante, nesse caso, também pode utilizar o conceito de área de um quadrado para responder ao item.

O professor pode, se desejar, adaptar esse exemplo e utilizá-lo e suas salas de aula para se construir o conceito de área de um quadrado.

Embora, nos últimos anos, os resultados das avaliações da Prova Brasil tenham mostrado uma melhora quanto ao ensino e aprendizagem de matemática, os índices ainda mostram que os estudantes apresentam várias dificuldades relacionadas à disciplina.

\footnotetext{
${ }^{11}$ Os Parâmetros Curriculares Nacionais (PCNs) são a referência básica para a elaboração das matrizes de referência, que são as habilidades esperadas dos alunos em diferentes etapas de escolarização. Os PCNs foram elaborados para difundir os princípios da reforma curricular e orientar os professores na busca de novas abordagens e metodologias. Disponível em: http://portal.mec.gov.br/seb/arquivos/pdf/matematica.pdf. Acesso em 13 abril 2016.
} 
Especificamente para a álgebra, os resultados da Prova Brasil mostram que os estudantes não dominam as seguintes competências:

- identificar um sistema de equações do $1^{\circ}$ grau que expressa um problema;

- resolver equações do $1^{\circ}$ grau com uma incógnita;

- resolver problemas que envolvam equação do $2^{\circ}$ grau;

- identificar as relações entre as representações algébrica e geométrica de um sistema de equações do $1^{\circ}$ grau;

- identificar, em um gráfico de função, o comportamento de crescimento/decrescimento;

- identificar o gráfico de uma reta dada sua equação.

Ao analisarmos as dificuldades dos estudantes, entendemos a necessidade de uma base algébrica, consistente e repleta de significados para os alunos, capaz de sustentar a posterior formação algébrica e a utilização de conceitos como ferramentas para manipulação e para solução de outros problemas, principalmente os associados a contextos reais.

\subsection{O Ensino e Aprendizagem de Álgebra}

A matemática em muitos casos, está repleta de formalismo, que, aliado à dificuldade de abstração, pode tornar-se inacessível para os estudantes, prejudicando seu estudo e aprendizagem.

Os conceitos e procedimentos matemáticos ensinados pelos professores nem sempre são entendidos de imediato, pelo contrário, exigem esforços que vão além de uma segunda explicação, exigem estratégias e ações que estreitem o relacionamento entre os estudantes e os conteúdos matemáticos, fazendo com que estes desejem, experimentar e compreender melhor a disciplina.

O trabalho de Ball, Thames e Phelps (2008 apud RIBEIRO, 2015, p.50), com base na categorização de Shulman é um importante referencial para os professores sobre os conhecimentos necessários para o ensino de matemática. Os autores subdividem esse conhecimento em:

- conhecimento comum do conteúdo: o conhecimento que engloba conceitos, propriedades, exemplos. O conhecimento aprendido nos cursos de ciências exatas; 
- conhecimento especializado do conteúdo: conhecimentos e habilidades matemáticas exclusivos do professor que permitem definir qual método é melhor para a solução de cada situação problema;

- conhecimento horizontal do conteúdo: conhecimento geral do que foi previamente ensinado e do que será nos anos seguintes. Esse conhecimento é fundamental para a transição entre os anos iniciais e finais do ensino fundamental;

- Conhecimento do conteúdo e dos estudantes: combina o que é necessário saber sobre Matemática e sobre as dificuldades e o pensamento dos alunos nessa disciplina, para planejar tarefas que partam de suas dificuldades e possam ser discutidas com eles;

- Conhecimento do conteúdo e do ensino: combina o conhecimento sobre a Matemática com o conhecimento sobre como ensinar tal conteúdo, como propor novas questões ou novas tarefas para os alunos.

Consideramos que o processo de ensinar não se limita a transmitir o conhecimento matemático, mas envolve despertar o interesse do aluno, tornando o ensino e a aprendizagem mais prazerosos e significativo $\mathfrak{s}^{12}$.

Para se ensinar é preciso que ocorra interação entre o professor e os alunos, devese buscar, no grupo para o qual se ensina, informações que possam ser entrelaçadas com o conteúdo matemático, sejam estas no sentido de contextualizar ou de partir do conhecimento matemático prévio do aluno para que se desenvolva os demais conteúdos. Ademais, é importante dar autonomia para que o aluno vá construindo os próprios conceitos para que seja ativo no processo de aprendizagem. Segundo Gil (2008),

[...]o papel do professor é fundamental, pois é dele que partem as tarefas que propiciam que o aluno faça relações, ou seja, produza significado para aquele estudo. É do professor que partem as intervenções, a fim de explorar situações em sala de aula que podem ser muito proveitosas para a construção do conhecimento. (p.41-42.) 28]

Ao professor, cabe a mediação, os questionamentos, as correções, o direcionamento para a formalização, visando que o aluno valide o que aprendeu. Os PCNs recomendam que o professor de matemática parta de um problema para que se chegue a formalização, valorizando os caminhos, as tentativas de solução, que permitem levantar as hipóteses e associá-las aos conteúdos matemáticos.

\footnotetext{
${ }^{12}$ Entendemos que a Teoria da Aprendizagem Significativa (AUSUBEL, 1976) é o processo por meio do qual um novo conhecimento se relaciona de maneira não arbitrária e não literal à estrutura cognitiva do estudante, pode-se afirmar que o conhecimento prévio trazido pelo estudante interage de forma significativa com o novo conhecimento e provoca mudança na estrutura cognitiva já existente. Tal mudança ou assimilação passa a ser chamada de aprendizagem significativa e está focada na aquisição e na retenção do conhecimento anteriormente adquirido (SILVA; SCHIRLO, 2014, p.42).
} 
O ensino de matemática pode apresentar falhas quando não há uma preocupação com o desenvolvimento e com a apropriação dos conceitos por parte dos alunos. Por meio da orientação do professor é que o estudante conclui e chega à sistematização das hipóteses e do conteúdo.

Ao direcionarmos o foco para o ensino de álgebra, de modo geral, percebemos que esse processo ainda acontece de forma mecanizadd 13 com exercícios repetitivos e que, em alguns casos, os professores, na tentativa de uma contextualização, fazem associações utilizando conceitos que serão abordados no Ensino Médio. Em outras palavras, acontece uma contraversão no processo de aprendizagem, partindo do formal para se chegar aos exemplos e modelos que permitem as generalizações.

Esse processo controverso é inadequado para o Ensino Fundamental, no qual o estudante está tendo suas primeiras experiências diretas com a álgebra, porque pode confundir o aluno, acarretando outras dificuldades quanto à aprendizagem.

O diagrama a seguir, apresenta as diferentes etapas da álgebra escolar, segundo os PCNs.

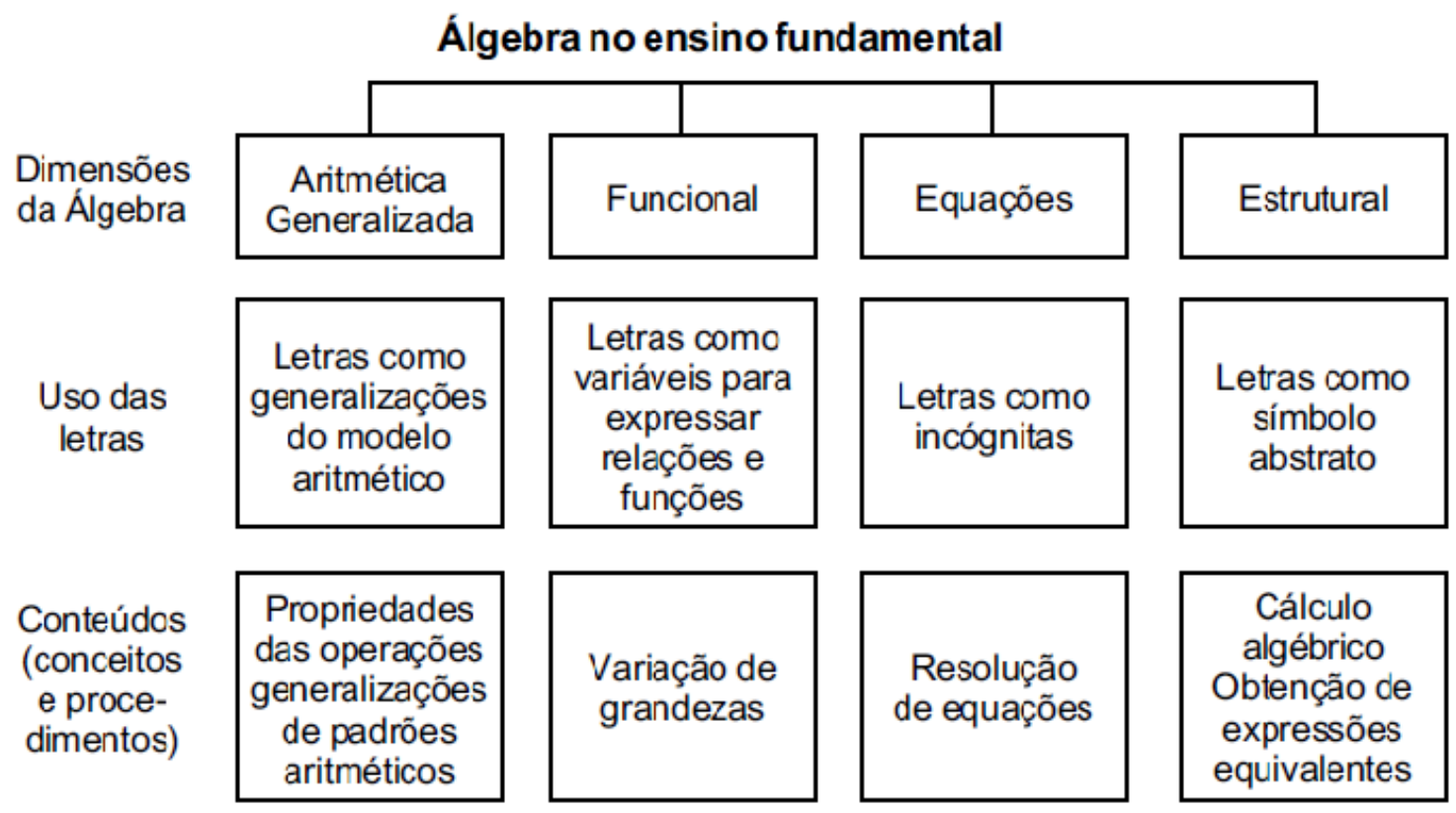

Figura 2.6: Interpretações da álgebra escolar (Brasil, 1998, p.116).

Essas interpretações e suas ramificações, muitas vezes, não são desenvolvidas em sua amplitude pelos professores, que podem até mesmo ignorar alguma das etapas, ou desvalorizá-la em detrimento de outra. De modo geral, os professores costumam

\footnotetext{
${ }^{13}$ Ensino mecanizado é uma expressão típica do contexto escolar e da literatura em Educação Matemática, e se aproxima da definição de Baldino [6] para Ensino Tradicional Vigente (ETV). O ensino mecanizado é um processo no qual o aluno "aprende" repetindo as ações mostradas pelo professor.
} 
priorizar os cálculos algébricos, a resolução de equações e estudo de funções, derivando do próprio processo de formação nos cursos de licenciatura em matemática.

Obviamente, não se trata de negar a aprendizagem de tais manipulações. Todavia, entendemos que a simples manipulação, desligada de significado, não é suficiente para garantir que o aluno realmente desenvolveu, compreendeu e apropriou-se do pensamento e da linguagem algébrica.

Para garantir uma aprendizagem significativa, é necessário que o professor compreenda a importância de cada etapa, recomendada pelos PCNs, para a formação algébrica do indivíduo. O estudante, ao perpassar este ciclo, deve ser incitado a partir das próprias experiências informais vivenciadas e das generalizações de contextos associados à aritmética para chegar à elaboração e à validação de novos conceitos.

Estruturar o pensamento teórico algébrico é um dos principais propósitos do professor de matemática para com seus alunos do Ensino Fundamental, tendo em vista as futuras manipulações de algoritmos e de abstrações que os aguardam no desenvolvimento algébrico em anos posteriores de suas formações. Assim, Brasil(1998) ${ }^{14}$ recomendam que:

[...]para uma tomada de decisões a respeito do ensino da Álgebra, devese ter, evidentemente, clareza de seu papel no currículo, além da reflexão de como a criança e o adolescente constroem o conhecimento matemático, principalmente quanto à variedade de representações. Assim, é mais proveitoso propor situações que levem os alunos a construir noções algébricas ela observação de regularidades em tabelas e gráficos, estabelecendo relações, do que desenvolver o estudo da Álgebra apenas enfatizando as manipulações com expressões e equações de uma forma meramente mecânica. (p.116) 12

Defendemos a organização pedagógica do processo de ensino e aprendizagem dotada de intencionalidade, amparada nos objetivos do professor, ou seja, que o professor, a partir dos seus conhecimentos dos conteúdos, didáticos e dos estudantes, elabore propostas que contemplem uma aprendizagem significativa dos conteúdos algébricos, permitindo aos discentes interação com o objeto de estudo e formulação de conceitos a serem discutidos, avaliados e validados.

A partir de toda essa discussão, Ribeiro (2015) propõe algumas ações que podem ser implementadas nos cursos de formação de professores em matemática e cursos de formação continuada, objetivando desenvolver conhecimentos matemáticos para o ensino de Álgebra. Entre essas ações, estão:

- a transposição didática dos conteúdos de Álgebra, de forma que atenda ao nível cognitivo e à linguagem entendida pelos estudantes. É importante que em um pri-

\footnotetext{
${ }^{14}$ Disponível em: http://portal.mec.gov.br/seb/arquivos/pdf/matematica.pdf. Acesso em 13 abril 2016.
} 
meiro momento, a linguagem tenha apenas o objetivo de transmitir a ideia, para posteriormente se chegar a formalização e a utilização da linguagem acadêmica.

- usar definições compreensíveis para o nível de ensino no qual elas são apresentadas;

- representar um mesmo conceito de várias maneiras, trazendo, quando possível, um modelo físico, um gráfico, uma tabela e o simbolismo correspondente. Ou seja, aproximar, sempre que possível, o conteúdo da realidade, atribuindo significados e associando-o a situações cotidianas vivenciadas pelo aluno;

- o professor deve manter contato com as dificuldades dos alunos em relação a determinado conceito, sejam suas perguntas e suas respostas para os exercícios as usuais ou as inesperadas;

- saber o que está sendo apresentado nos livros e exames e planejar questões que levem em conta esses tópicos. Dessa forma, o professor também será capaz de avaliar os materiais que lhe são oferecidos, desde apostilas e livros até mesmo os próprios exames.

- saber como avaliar as respostas dos alunos, não apenas para atribuir notas ou conceitos, mas para refletir sobre sua própria prática e para fazer as adaptações necessárias ao seu ensino, para propiciar aos alunos uma melhor aprendizagem.

É claro que entendemos que estes apontamentos não são suficientes e muito menos receitas prontas para o sucesso no ensino de matemática, mas apenas sugestões, baseadas nos resultados de pesquisas voltadas para o ensino e aprendizagem de matemática, mais precisamente, álgebra.

Tais sugestões devem ser avaliadas pelos professores, adaptadas segundo o seu conhecimento do conteúdo, dos estudantes e do ensino para que possam ser inseridas nas aulas de matemática. São propostas que buscam romper com o método tradicional e ensinar a matemática de forma mais significativa, possibilitando uma melhora qualitativa na aprendizagem.

A aprendizagem de álgebra e a apropriação da linguagem algébrica são desafios constantes nas salas de aula e, por essa razão, são temas que percorrem sistematicamente as reuniões e as discussões informais nas salas de professores, bem como a formalização por meio das pesquisas, leituras, bibliografias e experimentações de propostas de ensino em Educação Matemática.

Smith (2008 apud RIBEIRO, 2015, p.15), considera que há dois tipos de pensamento algébrico: o pensamento simbólico, que está associado a forma como o indivíduo 
compreende e usa um sistema simbólico e o pensamento representacional, que está associado aos processos cognitivos através dos quais o indivíduo constrói significados referenciais para algum sistema representacional. Smith define pensamento funcional como um pensamento representacional, no qual duas ou mais quantidades relacionadas variam.

\begin{abstract}
O pensamento representacional se caracteriza por tecer com o mundo uma relação que tem por objetivo principal reconhecê-lo. Num primeiro momento, na história do pensamento, essa relação seria puramente contemplativa e rememoradora. Essa contemplação seria feita por um pensador que se apoiaria em valores transcendentes universais, buscando atingir a verdadeira natureza das coisas, sua identidade, sua essência. A recognição nos permite, desse modo, atingir o elemento principal do modelo da representação: a identidade. (Bomfim e Mangueira, 2012, p.16.) 10
\end{abstract}

Bonfim e Mangueira (2012) caracterizaram o pensamento representacional, mostrando-nos que, de certa forma, este pensamento se aproxima do senso comum, principalmente por seu caráter de busca por verdades universais. Quando relacionamos ao ensino de álgebra, o pensamento representacional torna-se essencial para o reconhecimento dos padrões algébricos e para posterior identificação do processo de construção desses padrões.

A Associação de Professores de Matemática de Portugal (APM, 2007, p.39) propõe algumas habilidades que se espera que os estudantes desenvolvam, por meio do ensino e aprendizagem de álgebra, entre elas:

- compreender padrões, relações e funções;

- representar e analisar estruturas matemáticas usando símbolos algébricos;

- usar modelos matemáticos para representar e compreender relações quantitativas;

- analisar a variação em diversos contextos.

Embora o aluno já tenha tido algumas experiências relacionadas com a álgebra, é no Ensino Fundamental Anos Finais, que este processo de ensino e aprendizagem se formaliza, principalmente a partir do sétimo ano. Nesse momento, o professor tem a oportunidade de mostrar ao aluno uma importante ferramenta para a análise e resolução de problemas.

É válido ressaltar que, além de ser mais um instrumento para a resolução de problemas, a álgebra é fundamental para generalização de padrões, relacionar grandezas, entre outras habilidades que serão a base para a compreensão e desenvolvimento de outros processos, tais como o estudo de função e da própria modelagem matemática da vida real. 


\subsection{A passagem da aritmética para a álgebra: al- gumas considerações}

Os processos de ensino e aprendizagem de álgebra tem sido tema de várias pesquisas que envolvem professores e alunos. Entre os autores que pesquisam a aprendizagem de álgebra na Educação Básica, podemos citar Ribeiro (2001), Dreyfus e Hoch (2004), Lima (2007) e Dorigo (2010), que investigam a construção dos significados e a apropriação dos conceitos algébricos por parte dos estudantes, entre outros aspectos relacionados ao processo de ensino e aprendizagem.

Essas pesquisas revelam uma investigação acerca do conceito de equação, na qual Alessandro (2015) pontua que "os alunos não reconhecem as estruturas desse ente matemático, não são capazes de apresentar uma caracterização para esse conceito e somente evocam os procedimentos e técnicas de resolução". Esses pensamentos, legitimam a critica de Kieran (2004) a respeito da priorização das atividades transformacionais e procedimentos técnicos com relação às atividades geracionais e globais, associadas à apropriação dos conceitos.

Há também as pesquisas que tem como foco os professores, seus conhecimentos e suas formas de se ensinar. Dentre elas destacam-se os estudos de Zuffi (1999 apud RIBEIRO, 2015), Attorps (2003 apud RIBEIRO, 2015) e Barbosa (2009 apud RIBEIRO, 2015), que ao investigarem a maneira como os professores compreendem os conceitos de equação e função, mostram que

[...]há vários problemas relacionados ao ensino e a aprendizagem de equações e funções, os quais estão, normalmente, relacionados ao fato das equações e funções serem frequentemente compreendidas como um "amontoado" de símbolos, regras e procedimentos, muitas vezes desprovidos de significado. [10]

O entendimento dos professores a respeito do conceito de equação se aproxima bastante da compreensão dos alunos, mostrando que este modelo tradicional de ensino tem sido reproduzido e que a aprendizagem significativa não tem sido alcançada. Isso se deve, em grande parte ao fato de que a construção de um conceito por parte de um indivíduo não é um processo simples e que possa ser mecanicamente transferido. Essa elaboração conceitual embasa-se em um emaranhado de outros conceitos e inquietações que o indivíduo já carrega consigo.

O professor tem a capacidade de incitar, orientar, direcionar esse processo de apropriação para que o aluno chegue à homologação. Entretanto, há que se ter cuidado ao fazer essa mediação para que a inserção não tome o lugar da construção do conceito, mesmo que não seja intencional. Ribeiro (2015), afirma que: 
A formação de um conceito por um indivíduo não é um processo pontual ou imediato... partes do conceito vão sendo agregadas a outros elementos, tornando-se um amálgama que, posteriormente, pode vir a ter a clareza, a precisão e o detalhamento exigidos pela comunidade - acadêmica ou não, dependendo do tipo de conceito em questão. (p.20).[55]

É importante salientar que a construção de conceitos pode variar entre os indivíduos, conforme suas percepções e experiências. Ademais pode variar para o próprio indivíduo, tendo em vista que este passa por constante processo de formação e vivencia experiências em diferentes contextos. Embora existam estes conceitos e suas particularidades, deve-se lembrar que, para os matemáticos, existe sempre um conceito formal, que é o aceito pela academia e pela comunidade matemática.

Utilizaremos as definições de Tall e Vinner (1981) para elucidar as definições de imagem de conceito e definição de conceito, que consolidarão algumas definições a respeito do processo de construção de um conceito.

\section{Definições de Tall e Vinner (1981)}

\begin{tabular}{|c|c|}
\hline Imagem de Conceito & Definição de Conceito \\
\hline $\begin{array}{l}\text { - Descreve a estrutura cognitiva to- } \\
\text { tal que é associada ao conceito, } \\
\text { que inclui todas as imagens men- } \\
\text { tais e propriedades e processos as- } \\
\text { sociados. } \\
\text { - É construída ao longo dos anos, } \\
\text { através de experiências de to- } \\
\text { dos os tipos, mudando à medida } \\
\text { que o indivíduo encontra novos } \\
\text { estímulos e amadurece. }\end{array}$ & $\begin{array}{l}\text { - É uma maneira de usar palavras } \\
\text { para especificar o conceito em } \\
\text { questão. } \\
\text { - Pode ser aprendido por um } \\
\text { aluno somente por memorização } \\
\text { mecânica ou de maneira significa- } \\
\text { tiva, relacionando-se em maior ou } \\
\text { menor grau com o conceito como } \\
\text { um todo. } \\
\text { - É o que o aluno evoca da imagem } \\
\text { daquele conceito. }\end{array}$ \\
\hline
\end{tabular}

São notórias as variações que os conceitos matemáticos sofreram ao longo da história, para que se pudesse chegar aos conceitos atualmente aceitos pela comunidade matemática. Tais transformações e construções são variações que também ocorrem em todas as outras ciências.

Ao analisar o contexto histórico, entendemos que os conceitos de variável e incógnita não foram construídos de forma simples e que só passaram a existir posteriormente. Booth(2003, apud BONADIMAN, 2007, p.37) pontua que o conceito de 
variável é primordial para o estudo da álgebra, uma vez que seus estudos apontam que uma das principais diferenças entre a aritmética e a álgebra consiste na utilização de letras para indicar valores desconhecidos.

Booth(2003 apud BONADIMAN, 2007, p.37) afirma que os estudantes costumam associar um valor fixo para cada letra, descaracterizando-a como variável, isso porque, na aritmética, os símbolos (números) estão sempre associados a uma mesma quantidade.

Bonadiman(2007) considera que além de conhecer as dificuldades dos estudantes relacionadas ao conceito de variável, cabe ao docente pesquisar e utilizar práticas pedagógicas que permitam a inserção desse conceito no contexto de transição da aritmética para a álgebra.

Um exemplo interessante que podemos citar são os estudos de Ribeiro (2015), por meio de bibliografias e pesquisas, envolvendo professores e alunos, sobre o significado de equação. Estes estudos mostram a diversidade de significados que carregam o conceito "equação", aspecto classificado pelo autor como "multissignificados".

Nestes trabalhos, a maioria dos significados declarados pelos professores e alunos nas pesquisas, estavam associados ao significado intuitivo-pragmático, ou seja, tais conceituações a respeito de equações estavam intimamente ligadas a dimensão prática, que envolviam fórmulas ou algoritmos para resolução.

Após seus estudos Ribeiro (2013, p.63), elaborou um quadro sintetizando em categorias "a aproximação entre os multissignificados de equação e as zonas de perfil conceitual de equação".

Perfis conceituais de equação. RIBEIRO (2013, p.63.)

\begin{tabular}{l|l|l}
\hline Categoria & Breve descrição & $\begin{array}{l}\text { Categoria(s) } \\
\text { originárias(s) }\end{array}$ \\
\hline Pragmática & $\begin{array}{l}\text { Equação interpretada a partir de problemas de } \\
\text { ordem prática. Equação admitida como uma } \\
\text { noção primitiva. Busca pela solução predomi- } \\
\text { nantemente aritmética. }\end{array}$ & $\begin{array}{l}\text { Pragmática. } \\
\text { Intuitiva. } \\
\text { Axiomática. }\end{array}$ \\
\hline Geométrica & $\begin{array}{l}\text { Equação interpretada a partir de problemas } \\
\text { geométricos. Busca pela solução predominan- } \\
\text { temente geométrica. }\end{array}$ & $\begin{array}{l}\text { Geométrica. } \\
\text { Dedutiva. }\end{array}$ \\
\hline Estrutural & $\begin{array}{l}\text { Equação interpretada a partir de sua estru- } \\
\text { tura interna. Busca pela solução predominan- } \\
\text { temente algébrica. }\end{array}$ & $\begin{array}{l}\text { Estrutural. } \\
\text { Generalista. } \\
\text { Tecnicista. }\end{array}$ \\
\hline Processual & $\begin{array}{l}\text { Equação interpretada a partir de processos de } \\
\text { resolução. Busca pela solução aritmética ou } \\
\text { algébrica. }\end{array}$ & $\begin{array}{l}\text { Processual. } \\
\text { Tecnicista. } \\
\text { Intuitiva. }\end{array}$ \\
\hline Aplicacional & $\begin{array}{l}\text { Equação interpretada a partir de suas } \\
\text { aplicações. Busca pela solução aritmética ou } \\
\text { algébrica. }\end{array}$ & $\begin{array}{l}\text { Pragmática. } \\
\text { Conjuntista. } \\
\text { Intuitiva. }\end{array}$ \\
\hline
\end{tabular}

Tabela 2.3: Categorias de um perfil conceitual de equação.

Após analisar pesquisas com professores e estudantes, orientadas para o estudo e conceituação de função, Ribeiro (2015,p.26) propõe a categorização das zonas de perfil 
conceitual de função, fundamentada nos trabalhos de Mortimer (1994) e elaborada por Machado (1998).

Perfis conceituais de função. RIBEIRO (2015, p. 27.)

\begin{tabular}{l|l}
\hline Conceito & Breve descrição \\
\hline Relação de ordem & $\begin{array}{l}\text { A ideia de ordenar, que está na origem da contagem } \\
\text { e da correspondência biunívoca, é um conceito primi- } \\
\text { tivo, encontrado desde a pré-história, estando limitada } \\
\text { a conjuntos discretos. }\end{array}$ \\
\hline Instinto de funcionalidade & $\begin{array}{l}\text { Esta zona está relacionada ao conceito de proporcio- } \\
\text { nalidade e à ideia de relação entre grandezas. }\end{array}$ \\
\hline Variação funcional & $\begin{array}{l}\text { Relaciona-se ao estudo da variação, com descrição } \\
\text { do comportamento de uma variável, mas se limita } \\
\text { a funções "bem comportadas", cujo gráfico é repre- } \\
\text { sentado por uma curva suave, sem saltos nem inter- } \\
\text { rupções, ou seja, a funções contínuas. }\end{array}$ \\
\hline Lei algébrica & $\begin{array}{l}\text { Essa zona caracteriza-se pela algebrização do conceito } \\
\text { de função, pela necessidade e encontrar uma lei para } \\
\text { representá-la. }\end{array}$ \\
\hline Conceito formal & $\begin{array}{l}\text { Nesse caso, a zona de perfil conceitual reporta-se à } \\
\text { definição formal de função, conforme foi estabelecida, } \\
\text { por exemplo, por Bourbaki, em 1939 }\end{array}$ \\
\hline
\end{tabular}

Tabela 2.4: Categorias de um perfil conceitual de função.

Machado (1998) conclui que os estudantes recorreram a mais de uma zona do perfil, segundo as necessidades das questões propostas. Mostra também que muitos destes estudantes utilizaram imagens como forma de representar o conceito de função.

Compreendendo essas necessidades de apropriação dos conceitos algébricos, BRASIL(1998) sugerem a utilização de outros recursos como: história da matemática, tecnologias de informação e comunicação (TIC) e jogos, considerando que estes devem ser utilizados visando facilitar a aprendizagem. 


\section{Capítulo 3}

\section{Diálogo sobre o ensino de álgebra via livro didático do Ensino Fundamental Anos Finais.}

O Programa Nacional do Livro Didático (PNLD) 17 iniciou-se em 1929, como Instituto Nacional do Livro (INL), com o objetivo de aumentar as produções de livros didáticos. Ao longo desses 87 anos, o programa foi reformulado e aperfeiçoado várias vezes, e é o mais antigo dos programas voltados para a distribuição de livros didáticos para estudantes da rede pública de ensino brasileira.

O objetivo desse programa é distribuir coleções de livros didáticos, acervos de obras literárias, obras complementares e dicionários, aos estudantes da educação básica, subsidiando o trabalho pedagógico dos professores.

O Ministério da Educação (MEC), a partir de uma avaliação dos livros e demais produções, publica o Guia de Livros Didático\$2 com resenhas das obras aprovadas. Cada escola recebe um guia, por meio do qual escolhem, entre as produções aprovadas e disponíveis, aqueles que melhor atendem ao seu projeto político pedagógico.

A Secretaria de Educação Básica (SEB) do Ministério da Educação (MEC), é responsável pela avaliação das obras e elaboração do guia de livros didáticos. Trata-se de uma análise ampla e criteriosa dos aspectos didático-pedagógicos feita por especialistas de várias instituições ligadas ao ensino, e culminam na produção de resenhas dos livros aprovados. Essas resenhas irão compor o guia de livros didáticos, distribuído pelo MEC, que é o referencial para a escolha dos livros nas escolas.

\footnotetext{
${ }^{1}$ Para saber mais sobre a história desse programa, acesse:

http://www.fnde.gov.br/programas/livro-didatico/livro-didatico-historico. Acesso em 10 junho 2016.

${ }^{2}$ Disponível em: http://www.fnde.gov.br/programas/livro-didatico/guias-do-pnld. Acesso em 10 junho 2016 .
} 
A escola tem autonomia para fazer a escolha do livro didático, a partir do guia disponibilizado pelo MEC. É importante que toda a equipe pedagógica da escola discuta e participe dessa seleção, considerando uma escolha que contemple o projeto políticopedagógico da escola, o aluno, o professor, e a realidade sociocultural vivenciada no contexto escolar.

Os livros didáticos selecionados são utilizados durantes três anos consecutivos, até que novamente sejam feitas outras escolhas. Cada escola opta por duas possibilidades de livros didáticos para cada disciplina, logo, quando não é possível atender a primeira opção, o Fundo Nacional de Desenvolvimento da Educação (FNDE) ${ }^{3}$ envia à escola a segunda coleção de livros escolhidos.

O programa distribui os livros de três em três anos, alternando entre os níveis de ensino. Por exemplo, em um ano distribui para todos os estudantes dos anos iniciais do ensino fundamental, no ano seguinte, para todos os estudantes dos anos finais do ensino fundamental, e posteriormente, para os do ensino médio. Logo, cada estudante deve conservar e devolver os livros ao final de cada ano, para que nos próximos dois anos sejam utilizados por outros estudantes.

O PNLD também atende alunos da educação especial, distribuindo obras didáticas em Braille de língua portuguesa, matemática, ciências, história, geografia e dicionários, democratizando e universalizando o acesso ao ensino.

Em 2012 houve um importante avanço quanto a disponibilização de materiais digitais a usuários da educação nacional. Por meio de acordos de cooperação entre o FNDE e instituições interessadas para a estruturação e a operação de serviço virtual para disponibilização de obras digitais, por meio de tecnologia que assegure o atendimento em escala nacional e proteja os direitos autorais digitais e a propriedade intelectual dos acervos.

Em 2012, pela primeira vez, as editores puderam inscrever no âmbito do PNLD 2014, objetos educacionais digitais complementares aos livros impressos. Esse novo material multimídia, que inclui jogos educativos, simuladores e infográficos animados, será enviado para as escolas em DVD para utilização pelos alunos dos anos finais do ensino fundamental no ano letivo de 2014. O DVD é um recurso adicional para as escolas que ainda não têm internet. Os novos livros didáticos trarão também endereços on-line para que os estudantes tenham acesso ao material multimídia, complemente o assunto estudado, além de tornar as aulas mais modernas e interessantes.

\footnotetext{
${ }^{3}$ O Fundo Nacional de Desenvolvimento da Educação (FNDE) é responsável por captar e distribuir recursos financeiros a vários programas do Ensino Fundamental. Ao financiar e executar esses programas, o FNDE reforça a educação de milhões de crianças brasileiras diretamente beneficiadas por ele. Para saber mais, acesse: ¡http://www.fnde.gov.br/fnde/institucionali. Acesso em 10 junho 2016.
} 
Já para o ano letivo de 2015, foi lançado em 2012 o edital que prevê que as editoras podem apresentar obras multimídia, reunindo livro impresso e livro digital. A versão digital deve trazer o mesmo conteúdo do material impresso mais os objetos educacionais digitais, como vídeos, animações, simuladores, imagens, jogos, textos, entre outros itens para auxiliar na aprendizagem. O edital também permite a apresentação de obras somente na versão impressa, para viabilizar a participação das editoras que ainda não dominam as novas tecnologias. Esse material será destinado aos alunos e professores do ensino médio da rede pública.

Propomos dialogar sobre o conteúdo algébrico nos livros didáticos de matemática do Ensino Fundamental Anos Finais, afim de perceber de que forma esses conceitos algébricos tem sido inseridos no contexto de sala de aula. Afinal, entendemos que aprender álgebra ultrapassa a manipulação e resolução mecanizada de expressões e equações, significa investigar, perceber generalizações, estabelecer relações além de interpretar e resolver problemas.

Parte dos problemas relacionados ao ensino de matemática, tem suas raízes na formação dos profissionais da educação. Muitas vezes, diante da carência na formação, o professor inspira-se no seus formadores e mantém suas práticas na sala de aula baseadas apenas nos livros didáticos que nem sempre dialogam com a realidade vivenciada pelos alunos. Logo, o seu papel de aproximar a matemática da realidade e torná-la mais uma ferramenta na formação integral do indivíduo é deixada de lado e passa-se a repetir os mesmos erros sofridos durante sua própria formação.

O livro didático não funciona em sala de aula como um instrumento auxiliar para conduzir o processo de ensino e transmissão de conhecimento, mas como o modelo-padrão, a autoridade absoluta, o critério último de verdade. Neste sentido, os livros parecem estar modelando os professores. O conteúdo ideológico do livro é observado pelo professor e repassado ao aluno de forma acrítica e não distanciada. (FREITAG, 1997, p.111). [26]

O livro didático é uma importante ferramenta para o ensino, cabendo ao professor fazer as seleções e adaptações para que este seja inserido no contexto de sala de aula, beneficiando os alunos no processo de aprendizagem e orientado-os segundo a intencionalidade do professor. Logo, é fundamental que o professor escolha adequadamente o livro didático a ser utilizado, pois diante dos recursos que a maioria das escolas públicas dispõe atualmente, ele torna-se indispensável para o processo de ensino e aprendizagem. 


\subsection{O livro didático escolhido}

Para essa proposta, selecionamos o livro indicado para o sétimo ano, com o título "Projeto Teláris" do autor Luiz Roberto Dante, editora Ática, $2^{\text {a }}$ edição, 2015.

O livro didático foi selecionado, por ser utilizado por professores participantes da pesquisa atuantes no Ensino Fundamental Anos Finais, bem como nas escolas nas quais os participantes da pesquisa atuam e também em outras escolas da rede pública do Distrito Federal.

O volume do sétimo ano do Ensino Fundamental, é composto por quatro unidades e nove capítulos, contendo exercícios e problemas, desafios, atividades orais, curiosidades relacionadas aos tópicos, jogos, tratamento da informação, testes e questões de avaliações oficiais, situações-problema contextualizadas, revisão cumulativa, leituras relacionadas à história da matemática.

As unidades e capítulos desse livro são intitulados:

\begin{tabular}{|c|c|}
\hline $\begin{array}{l}\text { Unidade } 1 \\
\text { Números inteiros e Geometria }\end{array}$ & $\begin{array}{l}\text { Capítulo } 1 \text { - Números inteiros } \\
\text { Capítulo } 2 \text { - Geometria: sólidos geométricos, } \\
\text { regiões planas e contornos }\end{array}$ \\
\hline $\begin{array}{l}\text { Unidade } 2 \\
\text { Números racionais e introdução à Álgebra }\end{array}$ & $\begin{array}{l}\text { Capítulo } 3 \text { - Números racionais } \\
\text { Capítulo } 4 \text { - Equações do } 1^{\circ} \text { grau com uma } \\
\text { incógnita }\end{array}$ \\
\hline $\begin{array}{l}\text { Unidade } 3 \\
\text { Álgebra e Geometria }\end{array}$ & $\begin{array}{l}\text { Capítulo } 5 \text { - Equações do } 1^{\circ} \text { grau com duas } \\
\text { incógnitas - Inequações do } 1^{\mathrm{o}} \text { grau com uma } \\
\text { incógnita - Sistemas } \\
\text { Capítulo } 6 \text { - Geometria: ângulos e polígonos }\end{array}$ \\
\hline $\begin{array}{l}\text { Unidade } 4 \\
\text { Proporcionalidade e Estatística }\end{array}$ & $\begin{array}{l}\text { Capítulo } 7 \text { - Proporcionalidade } \\
\text { Capítulo } 8 \text { - Matemática financeira: regra de } \\
\text { sociedade, juros simples e juros compostos } \\
\text { Capítulo } 9 \text { - Noções de Estatística e Probabi- } \\
\text { lidade }\end{array}$ \\
\hline
\end{tabular}

Tabela 3.1: Livro didático Matemática - Projeto Teláris.

Cada unidade é iniciada com atividades denominadas "Ponto de partida", composta por algumas questões que serão desenvolvidas na Unidade. Os capítulos se iniciam com imagens e um texto de introdução que preparam os alunos para as próximas descobertas no decorrer dos mesmos. Os capítulos são subdivididos em sessões que exploram exercícios, problemas, jogos entre outras atividades já citadas.

Dentro dos capítulos os conteúdos estão organizados da seguinte forma:

Capítulo 4 - Equações do $1^{\circ}$ grau com uma incógnita.

1. Introdução.

2. Letras em lugar de números. 
3. Expressões algébricas.

4. Equação, incógnita e solução ou raiz.

5. Equação do $1^{\circ}$ grau com uma incógnita.

6. Uma aplicação de equação: geratriz de uma dízima periódica.

Capítulo 5 - Equações do $1^{\circ}$ grau com duas incógnitas - Inequações do $1^{\circ}$ grau com uma incógnita - Sistemas.

1. Introdução.

2. Equações com duas incógnitas.

3. Sistemas de duas equações do $1^{\circ}$ grau com duas incógnitas.

4. Inequações.

5. Sistema de inequações do $1^{\circ}$ grau com uma incógnita

6. Revendo equações, inequações e sistemas.

Embora o livro introduza o ensino de álgebra explicitamente no capítulo quatro, nos capítulos anteriores encontramos alguns exemplos nos quais foram utilizados elementos algébricos, como por exemplo, incógnitas, algumas manipulações, generalizações, entre outros. Percebemos que o autor demonstra uma preocupação em mostrar algumas situações prévias, de forma a contribuir para o processo de dedução e generalização proposto em seu trabalho, no que se diz respeito a álgebra.

Vejamos o exercício da página 29 do livro, ainda no primeiro capítulo, no qual o autor propõe algumas equações.

$$
\begin{aligned}
& \text { 45. Determine o valor de a nos itens a seguir. } \\
& \text { a) }(+3)+(-5)=a a=-2 \\
& \text { b) } a+(-8)=0 a=+8 \\
& \text { c) }(+10)+a=0 a=-10 \\
& \text { d) } a+(+12)=24 a=12(a+12=24 \Rightarrow a=12)
\end{aligned}
$$

Figura 3.1: Exercício. (DANTE, 2015, p.29)

Ao mostrar as propriedades da potenciação em Z, na página 42, ainda no capítulo 1, o autor utiliza da linguagem formal algébrica em um processo de generalização e na página 65 do segundo capítulo, o autor utiliza o processo de generalização para concluir a Relação de Euler. 


\section{Propriedades da potenciação em $\mathbb{Z}$}

Analise, a seguir, as propriedades da potenciação em $\mathbb{Z}$.

\section{Produto de potências de mesma base}

Exemplos:

a) $(+2)^{3} \cdot(+2)^{4}=(+2)^{3+4}=(+2)^{7}$

De um modo geral, escrevemos: b) $(-3)^{6} \cdot(-3)^{2}=(-3)^{6+2}=(-3)^{5}$

Figura 3.2: Propriedade do produto de potências de mesma base - (DANTE, 2015, p.42)

\begin{tabular}{|c|c|c|c|c|}
\hline Nome do poliedro & Representação & Número de vértices $(V)$ & Número de faces $(F)$ & Número de arestas $(A)$ \\
\hline $\begin{array}{l}\text { Bloco retangular } \\
\text { ou paralelepipedo }\end{array}$ & & 8 & 6 & 12 \\
\hline $\begin{array}{l}\text { Prisma de base } \\
\text { pentagonal }\end{array}$ & & 10 & 7 & 15 \\
\hline $\begin{array}{l}\text { Prisma de base } \\
\text { triangular }\end{array}$ & & 6 & 5 & 9 \\
\hline $\begin{array}{l}\text { Pirâmide de base } \\
\text { triangular }\end{array}$ & & 4 & 4 & 6 \\
\hline $\begin{array}{l}\text { Pirâmide de base } \\
\text { quadrada }\end{array}$ & & 5 & 5 & 8 \\
\hline
\end{tabular}

20. Atividade em dupla

Com um colega, compare, para cada poliedro do exercicio anterior, a soma $V+F$ com o valor de $A$. $O$ que vocês descobriram? Os alunos devem perceber que $V+F=A+2$

21. Examine novamente a linha do bloco retangular no quadro do exercício 19 , agora com mais uma coluna.

\begin{tabular}{|c|c|c|c|c|c|}
\hline Nome do poliedro & Representação & $\boldsymbol{V}$ & $\boldsymbol{F}$ & $\boldsymbol{A}$ & $\boldsymbol{V}+\boldsymbol{F}=\boldsymbol{A}+\mathbf{2}$ \\
\hline $\begin{array}{c}\text { Bloco retangular } \\
\text { ou paralelepipedo }\end{array}$ & & 8 & 6 & 12 & $8+6=12+2$ \\
\hline
\end{tabular}

Escreva essa relação $(V+F=A+2)$ para os demais poliedros do quadro, $\begin{gathered}10+7=15+2 ; 6+5=9+2: \\ 4+4=6+2: 5+5=8+2\end{gathered}$

Aُ Você sabio?

Foi o matemático suiço Leonhard Euler (lê-se "Óiler") que descobriu a relaçâo entre o número de vértices $(V)$, de faces $(F)$ e de arestas $(A)$ em alguns poliedros, como os prismas e as 'pirâmides. Essa relação, representada por $V+F=A+2$, é conhecida como Relação de Euler.

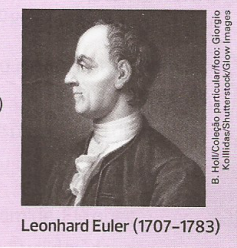

Figura 3.3: Exercícios. (DANTE, 2015, p.65) 
Em todos estes capítulos, pudemos notar a importância da manifestação do conteúdo algébrico. Embora, neste momento o aluno se valha de outros conhecimentos para solucionar os problemas, especialmente as soluções aritméticas, afinal, as manipulações algébricas ainda não foram inseridas no contexto, ocorre uma familiarização com a linguagem algébrica, podendo inclusive induzir o aluno a explorar e se apropriar dos conceitos algébricos antecipadamente, de forma ativa e construtiva em sua formação.

\subsection{Os capítulos do livro dedicados ao ensino de Álgebra}

Nos capítulos 4 e 5, o conteúdo algébrico é abordado como tema principal, conforme pode ser verificado na descrição dos capítulos do livro, feita anteriormente neste trabalho. Os objetivos desses capítulos ficam evidenciados no campo "Observações e sugestões para as Unidades e capítulos; indicações de leituras" (DANTE, 2015, p.57).

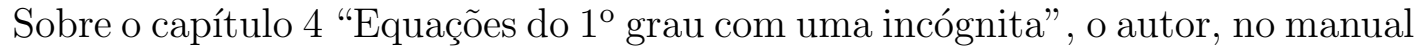
do professor, explica:

Nosso objetivo é evitar o cálculo algébrico mecânico e usar as letras de
forma significativa, explorando a passagem da linguagem usual para a
linguagem algébrica. Procuramos, na medida do possível, desenvolver
conceitos, procedimentos e atitudes positivas em relação a esta parte
da Matemática com o uso de situações contextualizadas, sem propor
cálculos enfadonhos e desprovidos de significado, próprios do ensino de
Matemática do passado.
As atividades foram elaboradas de modo que mostrassem que a lingua-
gem algébrica é uma poderosa ferramenta para resolver problemas e
para sintetizar, em fórmulas, certos fenômenos físicos, sociais, etc.
Assim, neste capítulo abordamos as seguintes dimensões da Álgebra:
aritmética generalizada, usando as letras como generalizações de
modelos; estrutural, empregando as letras como símbolo abstrato, ob-
tendo expressões algébricas equivalentes por meio de cálculos algébricos
simples integrados a no̧ões geométricas e de medidas; e, finalmente,
resolução de equações, em que as letras são incógnitas, sem ha-
ver necessidade de memorizar regras, dicas e atalhos sem significado. (DANTE, 2015.) [20]

O autor aborda aos poucos o conteúdo de equações, percorrendo as resoluções por cálculo mental, tentativa, operações inversas e ideia de equilíbrio (balanças), sugerindo situações-problema e valorizando as soluções. Ao propor os exercícios, percebemos que o autor utiliza situações possíveis de serem solucionadas por meio de cálculos aritméticos, e também outros exercícios nos quais torna-se necessário a representação algébrica, ou seja, induzindo os alunos a fazerem generalizações, discutirem os conceitos e se apropriarem da linguagem algébrica. 
Na página 117 temos um exemplo no qual o autor utiliza o que ele denomina "máquinas de números".

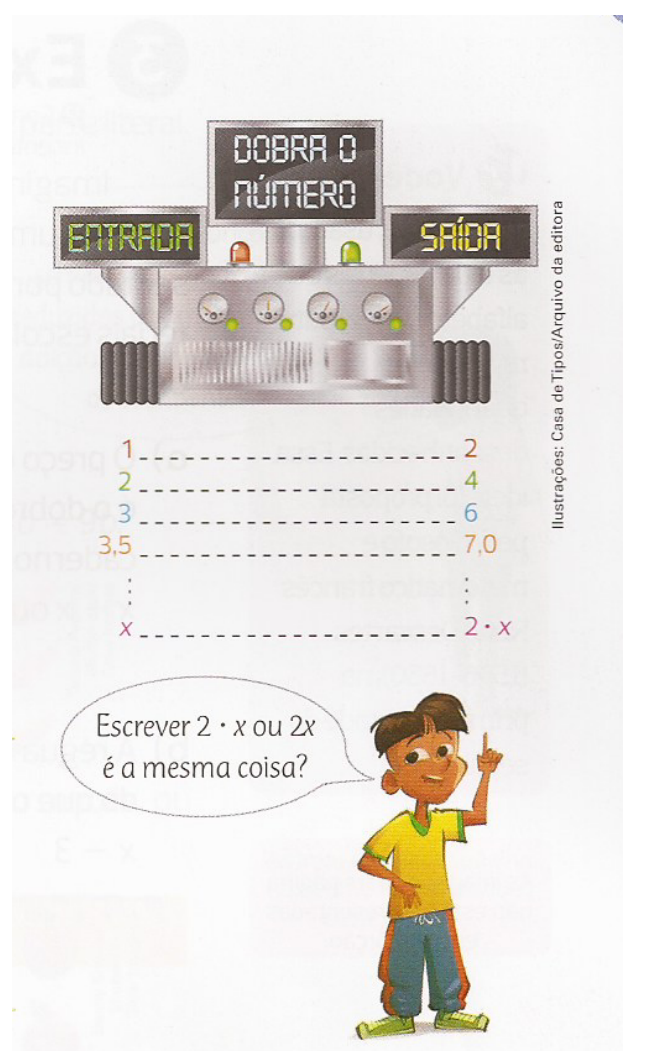

Figura 3.4: Máquinas de números. (DANTE, 2015, p.117.)

A máquina é utilizada com o objetivo de que o aluno perceba a transformação e compreenda a relação entre a função e a variável, chegando à generalização e utilizando a linguagem algébrica para representar simbolicamente a função escrita na máquina. Nesse exemplo, a função "dobra o número" pode ser expressa na forma "2.x".

Além das situações-problema propostas, há o entrelaçamento do conteúdo algébrico com os conteúdos de Geometria e Grandezas e Medidas, como por exemplo, a expressão do perímetro de alguns polígonos.

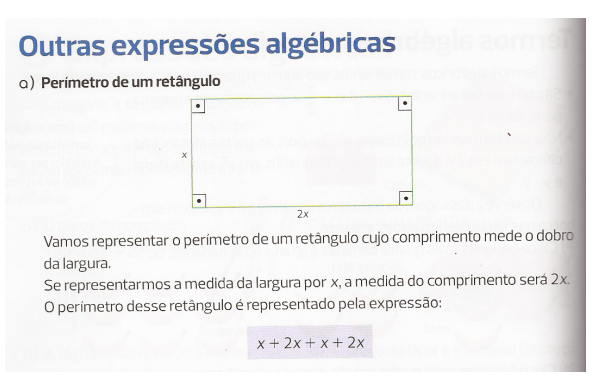

Figura 3.5: Exemplo de expressão algébrica aplicada à contextos geométricos e Grandezas e Medidas. (DANTE, 2015, p.120.) 
O autor também explora a ideia de equilíbrio e traz algumas ilustrações de balança para exemplificar.

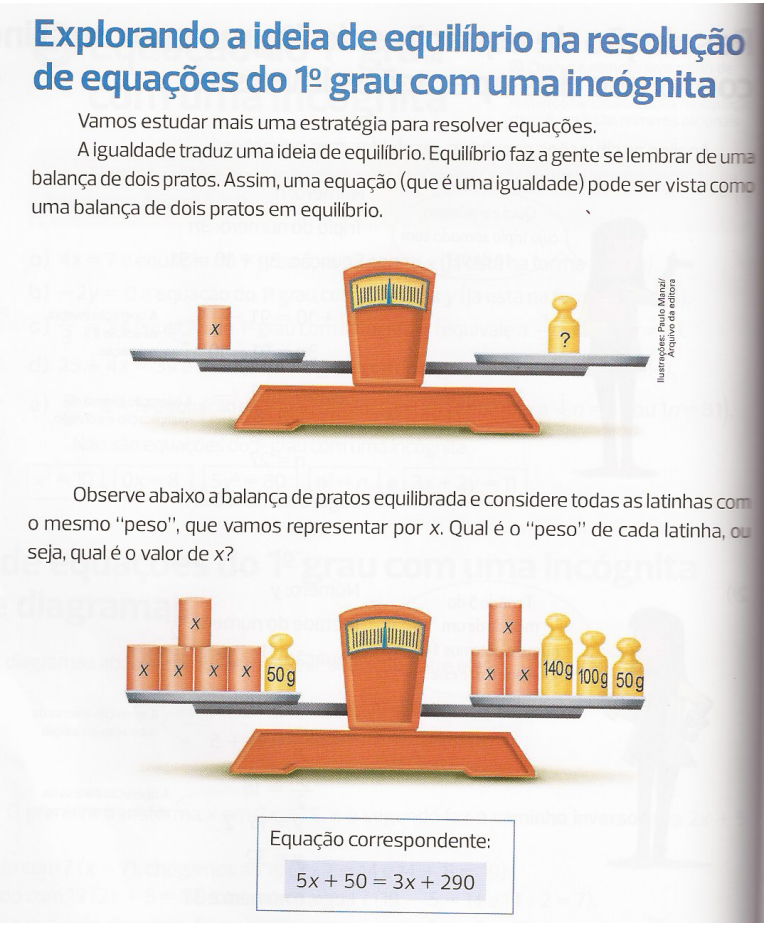

Figura 3.6: Exemplo de equações utilizando uma balança. (DANTE, 2015, p.134.)

Ao resolver questões como as propostas nesses exemplos, o aluno tem a oportunidade de investigar, formular hipóteses, elaborar e discutir conceitos. Uma vez que o professor adapta essa sugestão e leva o objeto concreto para a sua sala de aula, a aprendizagem torna-se carregada de significados, mais uma vez, evidenciando o relevante papel do material didático para o processo de aprendizagem.

É importante ressaltar que o livro também traz vários exercícios nos quais os alunos colocarão em prática os conceitos aprendidos, bem como a formalização da escrita algébrica e a utilização de manipulações algébricas, porém optamos por destacar, por meio das figuras, os exemplos contextualizados, e que demonstram determinado rompimento com os métodos tradicionais, ou seja, exemplos mais próximos da realidade do aluno e que carregam significados.

O capítulo 5 desse livro inicia-se com alguns exemplos de situações-problema que envolvem duas incógnitas e desigualdades.

Tendo em vista o conhecimento prévio dos alunos a respeito dos conceitos algébricos e de equação, já discutidos no capítulo anterior, o autor apresenta a equação do $1^{\circ}$ grau com duas incógnitas e mostra que sua solução é dada por um par ordenado de números racionais, inclusive utilizando a interpretação gráfica e geométrica dessas soluções encontradas. 
Por meio de situações-problema o autor introduz o conteúdo de sistemas de equações do $1^{\circ}$ grau com duas incógnitas. As atividades propostas no livro são solucionadas de várias formas, e o autor destaca a importância da valorização da solução do aluno, afinal, a apropriação dos conceitos e aprendizagem ocorre de forma particular, levando o aluno a construir um método próprio para se chegar à solução.

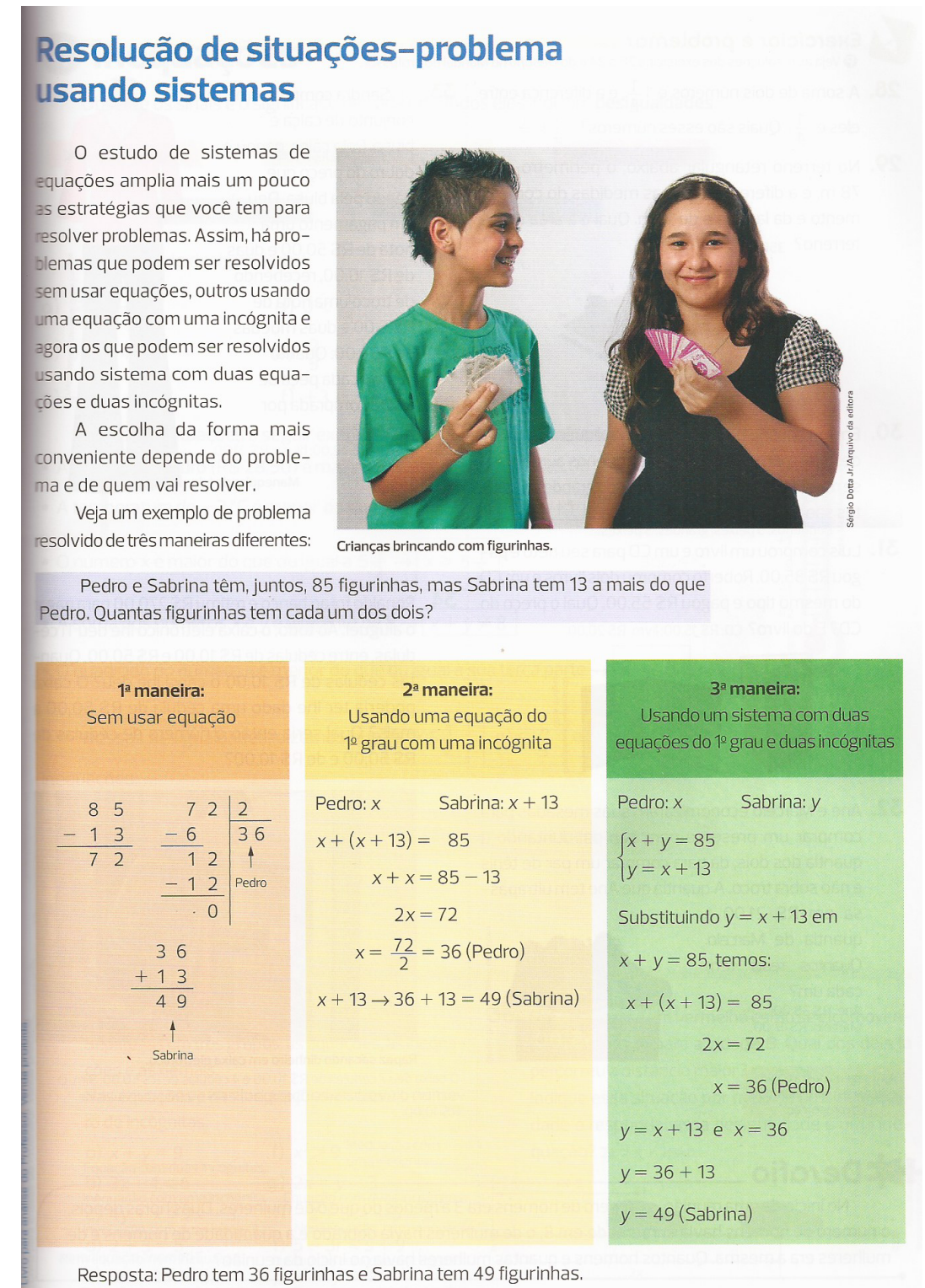

Figura 3.7: Resolução de situações-problema usando sistemas. (DANTE, 2015, p.165.)

O autor finaliza o capítulo com a sessão "Outros contextos", na qual propõe problemas contextualizados utilizando os conceitos construídos no capítulo.

O livro didático escolhido propõe uma discussão interessante acerca do processo de ensino e aprendizagem de álgebra. Notamos que mesmo nos capítulos que antecedem os conteúdos "Expressões Algébricas" e "Equações", os conceitos "variável" e 
"incógnita" são explorados, mesmo que de maneira intuitiva ou associada à aritmética, a partir de situações nas quais o estudante se depara com a ideia do desconhecido.

Consideramos que a proposta do autor, de antecipar a utilização de tais conceitos, mesmo que de forma intuitiva, permite a familiarização do estudante com o conteúdo algébrico. Contudo, auxilia para que ao deparar-se com a linguagem formal, o discente não sinta excessivo estranhamento, facilitando a apropriação dos conceitos algébricos.

O autor introduz o capítulo "Equações do $1^{\circ}$ grau com uma incógnita" discutindo duas situações-problema, próximas à realidade dos estudantes. São eles:

- uma empresa que faz reciclagem de papel

- dois jovens que decidem ir à um restaurante e na hora de pagar a conta, decidem dividi-la entre eles

Essa última situação, no entanto, é vivenciada constantemente pelos estudantes, o que facilita a compreensão do contexto e da problemática abordada, permitindo vislumbrar o problema de forma menos abstrata e inserida em um contexto real. Desse modo, a contextualização auxilia na identificação das incógnitas e também no processo de tradução da linguagem natural para a linguagem algébrica, permitindo que o estudante compreenda o simbolismo.

Em alguns momentos percebemos que as concepções do autor relacionam-se positivamente com a proposta desse trabalho, uma vez que no decorrer dos capítulos que tratam do ensino de álgebra, existem várias atividades que trabalham os conteúdos algébricos instituindo o valor da experiência. O autor utiliza a "máquina de transformações" para aproximar o estudante da ideia de dependência entre variável e expressão, introduzindo os princípios de função. Nesse momento, o desenho colorido da máquina, que é colocado no livro, caracteriza de forma mais próxima e real a situação representada, atribuindo significado a situação-problema.

Ao utilizar as ilustrações das balanças para o ensino de equações, o autor não só aproxima o conteúdo do contexto real, mas sugere e atenta o docente para a utilização de recursos como materiais concretos, possibilitando a elaboração de uma proposta de aula mais atrativa e diferente da tradicional, o que permite ao estudante compreender o que significa o procedimento de resolução de equação a partir dos princípios aditivos e multiplicativos.

As imagens, as curiosidades históricas, os desafios, as situações-problema próximas aos contextos reais e cotidianos, apontam para uma perspectiva de rompimento com o ensino mecanizado, valorizando a construção do conhecimento, a qual defendemos nesse trabalho. Não descartamos a importância da escrita e formalização algébrica, 
no entanto, o que sugerimos nessa pesquisa, que, nos aproxima da perspectiva desse autor, é valorizar o processo de transição da aritmética para a álgebra, construindo os conceitos a partir do conhecimento prévio dos estudantes, para, subsequentemente, chegar à formalização. 


\section{Capítulo 4}

\section{A relevância da experiência no processo de ensino e aprendizagem de matemática.}

\subsection{O que é a experiência?}

O desempenho dos alunos em Matemática tem sido bastante discutido nas últimas décadas, principalmente por apresentar-se como um desafio mundial. Pesquisas a respeito do fracasso na aprendizagem de matemática como as de Ferreira et al. (2007); Senos e Diniz (1998); Caldas e Hübner (2001); Tassoni (2000) apontam, a falta de motivação dos alunos como uma das principais interferências na aprendizagem escolar.

Esta desmotivação dos alunos pode ser explicada a partir da combinação de aulas tradicionais, repletas de conteúdos ensinados de forma mecanizada e sem significado, além de exercícios que não passam de repetições e fórmulas. Enfim, um ensino conteudista, desligado dos contextos reais e sociais.

É muito comum que o professor seja visto como o detentor de todo o conhecimento e o aluno considerado um depósito que a princípio está vazio, aguardando o despejar do professor. Essa postura é prejudicial para o processo de aprendizagem, pois descarta os conceitos já estruturados pelo aluno, bem como os conhecimentos adquiridos por meio de suas vivências dentro e fora do contexto escolar. Libâneo(1994), considera que: 
A aprendizagem escolar tem um vínculo direto com o meio social que circunscreve não só as condições de vida das crianças, mas também a sua relação com a escola e estudo, sua percepção e compreensão das matérias. A consolidação dos conhecimentos depende do significado que eles carregam em relação à experiência social das crianças e jovens na família, no meio social, no trabalho. (p.87). 37]

A distância entre os conteúdos matemáticos e as situações concretas também contribui para o desinteresse por parte dos alunos, logo, cabe a nós professores este papel de aproximação entre o aluno e o objeto de estudo. O professor deve estar ciente de que é preciso ir além em suas salas de aula e também da importância de valorizar os conhecimentos dos alunos como um todo, para que estes possam interpretar suas vivências e suas aprendizagens relacionando-as à vida social.

Estes conhecimentos serão os pontos de partida para a aquisição de outros novos, bem como a elaboração de conceitos e estruturação das constantes aprendizagens. Para Bulgraen (2010)

[...]a relação de ensino estabelecida na sala de aula, o professor precisa ter o entendimento de que ensinar não é simplesmente transferir conhecimento, mas, ao contrário, é possibilitar ao aluno momentos de reelaboração do saber dividido, permitindo o seu acesso critico a esses saberes e contribuindo para sua atuação como ser ativo e crítico no processo histórico-cultural da sociedade. (p.37). [14]

Pretendemos destacar as diferenças e individualidades dos sujeitos que aprendem, uma vez que ninguém aprende pelo outro, e neste sentido temos a noção essencial da atividade como base primária e primeira dos processos de aprendizagem (LEONTIEV, 1978) [36]. É importante que o estudante levante hipóteses, construa conceitos e valide-os, para que o conhecimento extrapole o contexto escolar, que lhe seja útil em outras situações. Ao professor cabe o papel de dominar o conteúdo, apropriar-se de metodologias de ensino, fazendo as adaptações necessárias, adequando-as ao grupo de sujeitos no qual atua. É fundamental esta compreensão de papéis para que seja estabelecido o processo dialógico de ensino e aprendizagem. O professor fazendo a mediação entre o sujeito e o objeto, orientando e estando suscetível a aprendizagem.

Neste sentido os trabalhos de investigação tem ganhado cada vez mais espaço nas pesquisas, nos ambientes de formação, laboratórios de matemática e como consequência, nas salas de aula. Frota(2005) afirma que

[...]práticas investigativas introduzidas na sala de aula de matemática parecem ser cruciais para o desenvolvimento de uma postura especulativa em matemática, podendo gerar também, um deslocamento do foco da aula, do professor para o aluno, no sentido de uma aula mais colaborativa. Atividades de investigação podem conformar uma concepção de matemática como algo dinâmico, do conhecimento matemático como em construção, através do desenvolvimento de idéias e processos, constituintes do pensar e fazer matemáticos. (p.2) 27] 
Na sua essência, a atividade matemática é definida como resolução de problemas, conceito intimamente ligado à atividade investigativa, principalmente por serem processos carregados de indagações. Todavia, o processo investigativo é um tanto mais complexo, pois visa uma maior exploração das etapas do desenvolvimento do pensamento matemático do sujeito. Para Lorenzato (2008) "Experimentar é valorizar o processo de construção do saber em vez do resultado dele, pois, na formação do aluno, mais importante que conhecer a solução é saber como encontrá-la. Enfim, experimentar é investigar" (p.72).

Destacamos a relevância da experiência no processo de aprendizagem de matemática, que não deve ser compreendida apenas como as experiências vivenciadas em situações reais do dia a dia, ou ainda, necessariamente concretas, mas também aquelas propostas dentro de um ambiente investigativo em sala de aula e que podem gerar produção e desenvolvimento de significados e conceitos.

Concordamos com Frota (2005), que uma experiência matemática carrega tanto o caráter individual por ser personalizada e única, uma vez que essa história é vivida, quanto o caráter coletivo, cultural e político, uma vez que é vivenciada por pessoas com uma história, inseridas numa cultura, parte de uma comunidade.

Hartmann(2014) destaca a importância de se experimentar a matemática na escola, pois muitas vezes os alunos não conseguem aprender por não atingirem níveis de abstração. Nesse contexto surge o processo investigativo como ferramenta para que estes alunos consigam se desenvolver, averiguar e gostar de construir a matemática. É fundamental que o estudante busque os caminhos, que as respostas não sejam contadas e que o professor, sabiamente, crie um ambiente propício, forneça instrumentos e faça a mediação necessária para que o aluno permaneça em constante processo de aprendizagem. Todavia, proporcionando ao docente atingir o objetivo de ensinar.

As atividades de ensino são definidas por Moura (1996), como a

[...]materialização dos objetivos e conteúdos, define uma estrutura interativa em que os objetivos determinam conteúdos, e estes por sua vez concretizam esses mesmos objetivos na planificação e desenvolvimento de atividades educativas. (p.30) 47 .

As atividades de ensino propostas nesse trabalho são dotadas de intencionalidade, pois propiciam a interação entre os sujeitos e estão relacionadas ao conteúdo matemático de expressões algébricas e possibilitam o contato com tais conceitos algébricos por meio da experiência. 


\subsection{O clube de matemática}

Já citamos em outros momentos deste trabalho, a influência do Clube de Matemática na formação da pesquisadora, bem como para a escolha do tema a ser pesquisado. Nesta seção detalharemos a proposta e o trabalho desenvolvido pelo clube de matemática.

O projeto Clube de Matemática, desenvolvido em 2011, se constituía em um ambiente no qual elaborávamos as propostas, atividades de ensino e jogos que seriam utilizados posteriormente nos encontros com os estudantes participantes do Clube de Matemática, nas escolas públicas de Goiânia.

Naquele momento, integravam o Clube de Matemática, o professor coordenador, três alunos do curso de Especialização em Educação Matemática e professores do Ensino Fundamental Anos Finais da rede pública de ensino, além de um aluno do curso de licenciatura em matemática e grande colaborador nas propostas. Também participavam do projeto estudantes, do Ensino Fundamental Anos Finais, das escolas públicas nas quais trabalhavam os professores participantes do projeto.

O Clube de Matemática é um projeto educativo vinculado ao programa Observatório da Educação da CAPES円(OBEDUC) e desenvolvido pelos estudantes dos cursos de Licenciatura em Matemática da UFG, de Pedagogia da UFG, de Pós-graduação da UFG e professores de matemática do Ensino Fundamental, com estudantes do Ensino Fundamental da rede pública.

Sob minha orientação, participavam das atividades do Clube, 12 estudantes do $5^{\circ}$ ano, da Escola Municipal Hebert José de Souza 2 . Estudantes que se inscreveram voluntariamente, após a divulgação do projeto na escola. As atividades eram realizadas no contraturno do horário regular das aulas, ou seja, a professora e estes estudantes se reuniam todas as quarta-feiras no turno vespertino.

O objetivo principal do Clube de Matemática é "criar um ambiente para o desenvolvimento de atividades educativas que possibilitem a discussão dos mais variados aspectos dentro do meio educacional." (CEDRO, 2004, p.52). [16] Pretendíamos propiciar aos estudantes interação com atividades diferenciadas, caracterizadas pela ludicidade, despertando o interesse pelo conhecimento matemático e facilitando o processo de aprendizagem. Por meio destas experiências, nós professores conseguíamos um feedback que possibilitava a discussão e compreensão do processo de ensino e aprendizagem, por meio de atividades lúdicas e diferentes das tradicionais.

As atividades de ensino utilizadas no Clube de Matemática, foram elaboradas

\footnotetext{
${ }^{1}$ Site: http://www.capes.gov.br/educacao-basica/observatorio-da-educacao. Acesso em 10 abril 2016.

${ }^{2}$ Site: http://escolahebertjosedesouza.blogspot.com.br/. Acesso em 10 abril 2016.
} 
nos encontros semanais que aconteciam entre os professores e coordenador. Estas reuniões eram necessárias para leituras e reflexões sobre dificuldades relacionadas ao ensino de matemática, mais especificamente de álgebra e discussões sobre metodologias, ferramentas e possibilidades de soluções para as falhas de aprendizagem apresentadas. Além disso, nos encontros eram avaliadas, reestruturadas, adaptadas, e principalmente criadas várias atividades de ensino que contribuíam para o processo de aprendizagem de forma contextualizada e mais lúdica.

As atividades de ensino definidas por Moura(1996) como

[...]materialização dos objetivos e conteúdos, define uma estrutura interativa em que os objetivos determinam conteúdos, e estes por sua vez concretizam esses mesmos objetivos na planificação e desenvolvimento de atividades educativas. (p.30). 47 .

Dessa forma, as atividades de ensino que utilizaremos nesse trabalho são dotadas de intencionalidade, pois propiciam a interação entre os sujeitos e estão relacionadas ao conteúdo matemático de expressões algébricas. Moura (1996) aponta que:

A atividade de ensino que respeita os diferentes níveis dos indivíduos e que define um objetivo de formação como problema coletivo é o que chamamos de atividade orientadora de ensino. Ela orienta o conjunto de ações em sala de aula a partir de objetivos, conteúdos e estratégias de ensino negociado e definido por um projeto político pedagógico. Contem também elementos que permitem à criança apropriar-se do conhecimento como um problema. E isto significa assumir o ato de aprender como significativo tanto quanto o ponto de vista psicológico quanto de sua utilidade. (p.32). [47.

Percebemos as atividades de ensino como grandes aliadas na proposta de ensino e aprendizagem, afinal, ao longo do trabalho os alunos compreenderam a matemática de forma mais significativa e associando estas atividades aos jogos vimos que os resultados foram ainda mais satisfatórios, devido à contribuição do aspecto lúdico para o interesse do aluno em participar das atividades propostas no Clube de Matemática.

Durante o desenvolvimento do projeto na escola, foram propostos 12 encontros, sendo o primeiro e último voltados para apresentação e encerramento, respectivamente. Nos demais encontros aplicou-se as seguintes atividades:

- Boliche Matemático

- Máquina Mágica

- Trilha das leis

- Batalha naval 
- Corrida dos sacos

- Trilha dos desafios

• "Ãh! Como assim? Que língua é essa?"

- Caça ao tesouro

- Balão

- Movimento Certo

Ensinar álgebra parecia ainda mais desafiador do que ensinar os demais conteúdos, era essa a impressão que trazíamos ao longo da experiência em salas de aula do ensino fundamental. Afinal, a álgebra se constitui de uma linguagem própria e totalmente simbólica e todo esse formalismo leva o aluno a simples manipulação, seguindo modelos em situações padronizadas e totalmente destituídas de significado.

Em minhas experiências em turmas de $7^{\circ}$ ano onde geralmente se inicia o contato com a álgebra, não era difícil notar que a principal dificuldade dos alunos estava em relacionar a linguagem natural (língua portuguesa) à linguagem algébrica.

Dentro do Clube de Matemática os conceitos são anunciados através de situações-problema, jogos, com a utilização de recursos midiáticos, ou seja, são situações que se aproximam das experiências vivenciadas pelos alunos no cotidiano, por isso tornam-se mais atrativas do que os métodos tradicionais, com exercícios e exemplos distantes da realidade. As atividades despertam o interesse dos estudantes e permitem que eles percebam a aplicação matemática em situações problemas reais.

Alguns resultados obtidos por meio do projeto Clube de Matemática, podem ser apreciados a partir do livro "Clube de Matemática: vivências, experiências e reflexões." [17] e trabalhos científicos que surgiram e continuam sendo produzidos e publicados. Entre eles podemos citar: ANDRADE (2009), ACHEGAUA SALAZAR(2013), ACHEGAUA SALAZAR (2015), OLIVEIRA (2013), SILVA (2013), CEDRO (2015), OLIVEIRA (2014).

\subsection{As atividades de ensino e jogos escolhidos}

Nesta sessão iremos exibir as três atividades de ensino que serão utilizadas neste trabalho: Boliche Matemático, Trilha das Leis e Batalha Naval. Estas três atividades foram desenvolvidas pelo Clube de Matemática 2011/2012 do IME/UFG $3^{3}$ e reestruturadas pelos novos membros do projeto Clube de Matemática em 2013.

\footnotetext{
${ }^{3}$ Coordenador: Wellington Lima Cedro, Participantes: Douglas Aires da Silva, Érico Mortari, Gabriela de Araújo Achegaua Salazar, Ludimila Cássia Coelho de Andrade.
} 
Utilizaremos a versão das atividades de ensino propostas no trabalho de Oliveira (2014), por serem as versões finais e atualizadas. Neste trabalho, Oliveira se refere a estas atividades de ensino como Situações desencadeadoras de aprendizagem (SDA), pois "foram elaboradas na busca de situações que promovessem a partilha de diferentes saberes, de forma coletiva, mediados por um conteúdo." (OLIVEIRA, 2014, p.8).

As três tabelas abaixo referem-se as atividades de ensino que serão utilizadas neste trabalho e que serão melhor detalhadas a seguir.

\section{Atividade 1 - Boliche Matemático}

\begin{tabular}{l|l}
\hline Autoria & Clube de Matemática 2011/2012 do IME/UFG. \\
\hline Objetivo & Desenvolver a ideia de variável e de dependência entre duas grandezas. \\
\hline $\begin{array}{l}\text { Material para con- } \\
\text { fecção }\end{array}$ & $\begin{array}{l}\text { Jogo de boliche com pinos e bola, papel A4. Sugestão: Pode-se usar 10 } \\
\text { garrafas pet contendo um pouco de areia e uma bola comum. }\end{array}$ \\
\hline $\begin{array}{l}\text { Material utilizado } \\
\text { para o jogo }\end{array}$ & Jogo de boliche com pinos e bola, caneta e folhas de registro da atividade. \\
\hline
\end{tabular}

Tabela 4.1: Atividade Boliche Matemático

\section{Atividade 2 - Trilha das Leis}

\begin{tabular}{l|l}
\hline Autoria & Clube de Matemática 2011/2012 do IME/UFG. \\
\hline Objetivo & Desenvolver a ideia de dependência entre as variáveis de uma função. \\
\hline $\begin{array}{l}\text { Material para con- } \\
\text { fecção }\end{array}$ & $\begin{array}{l}\text { papel A4, impressão colorida, tesoura, retalhos de EVA colorido. Su- } \\
\text { gestão: plastificar o tabuleiro e as cartas do jogo para maior durabili- } \\
\text { dade. }\end{array}$ \\
\hline $\begin{array}{l}\text { Material utilizado } \\
\text { para o jogo }\end{array}$ & $\begin{array}{l}\text { Tabuleiro e cartas do jogo, peças de EVA para marcar a posição dos } \\
\text { jogadores, um dado, caneta e registro da atividade. }\end{array}$ \\
\hline
\end{tabular}

Tabela 4.2: Atividade Trilha das Leis

\section{Atividade 3 - Batalha Naval}

\begin{tabular}{l|l}
\hline Autoria & Clube de Matemática 2011/2012 do IME/UFG. \\
\hline Objetivo & $\begin{array}{l}\text { Desenvolver a ideia de função por meio do estabelecimento da premissa } \\
\text { de que para cada membro de um conjunto há um correspondente em } \\
\text { outro. }\end{array}$ \\
\hline $\begin{array}{l}\text { Material para con- } \\
\text { fecção }\end{array}$ & cartolina branca, tesoura, pincel atômico, régua, lápis, caneta, papel A4. \\
\hline $\begin{array}{l}\text { Material utilizado } \\
\text { para o jogo }\end{array}$ & $\begin{array}{l}\text { campo de batalha construído na cartolina, marcador permanente, campo } \\
\text { de batalha impresso em papel A4, lápis e folha de registro. }\end{array}$ \\
\hline
\end{tabular}

Tabela 4.3: Atividade Batalha Naval

\subsubsection{Boliche Matemático}

Nesta atividade a turma é dividida em duas equipes, contendo seis estudantes. Cada equipe recebe uma folha de registro, na qual anotará a contagem dos pontos nesse primeiro momento da atividade. 
Capítulo 4. A relevância da experiência no processo de ensino e aprendizagem de matemática.

Alunos (grupo):

Boliche matemático $-1^{\circ}$ momento

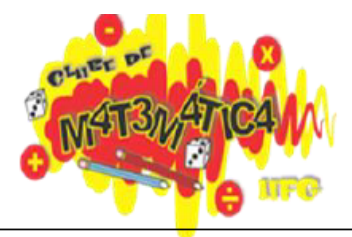

Nessa tabela você irá marcar os pontos dos seus grupos em cada rodada.

\begin{tabular}{|c|c|c|c|c|c|}
\hline \multicolumn{2}{|c|}{ RODADA DO DOBRO } & \multicolumn{2}{|c|}{ RODADA DO TRIPLO } & \multicolumn{2}{|c|}{$\begin{array}{l}\text { RODADA DO } \\
\text { QUÍNTUPLO }\end{array}$} \\
\hline Jogador 1 & Pinos & Jogador 1 & Pinos & Jogador 1 & Pinos \\
\hline Jogador 2 & Pinos & Jogador 2 & Pinos & Jogador 2 & Pinos \\
\hline Jogador 3 & Pinos & Jogador 3 & Pinos & Jogador 3 & Pinos \\
\hline Jogador 4 & Pinos & Jogador 4 & Pinos & Jogador 4 & Pinos \\
\hline \multicolumn{2}{|c|}{ Quantidade total de pinos } & \multicolumn{2}{|c|}{ Quantidade total de pinos } & \multicolumn{2}{|c|}{ Quantidade total de pinos } \\
\hline \multicolumn{2}{|c|}{ Pontos totais da rodada } & \multicolumn{2}{|c|}{ Pontos totais da rodada } & \multicolumn{2}{|c|}{ Pontos totais da rodada } \\
\hline
\end{tabular}

Pontuação final do jogo:

Conclusões:

Figura 4.1: Folha de Registro Boliche Matemático - $1^{\circ}$ momento

A atividade boliche matemático aproxima-se de um jogo de boliche tradicional, mantendo-se algumas regras, exceto para o cálculo de pontuação da equipe. Neste primeiro momento são feitas três rodadas de lançamentos (do dobro, do triplo e do quíntuplo, respectivamente), nas quais cada estudante tem direito a um lance. Um 
pino derrubado vale 1 unidade e ao final do primeiro momento os estudantes devem calcular a quantidade de pinos derrubados e partir do comando da rodada (dobro, triplo, quíntuplo) calcular também a quantidade de pontos totais das rodadas e a pontuação final do jogo. Vence esse primeiro momento, a equipe que conseguir a maior pontuação final.

É importante que neste momento o professor faça uma intervenção e dialogue sobre a atividade realizada. Os estudantes devem ser instigados a falar sobre o método utilizado para calcular a pontuação, bem como em qual das rodadas poderia-se atingir um maior número de pontos.

No segundo momento da atividade, as rodadas não são pré definidas (dobro, triplo e quíntuplo). Cada grupo de estudantes, ao final das três rodadas, irá decidir, de forma mais conveniente, qual rodada será validada como a do dobro, do triplo e do quíntuplo. Estas rodadas terão que ser definidas a partir de um novo objetivo que se estabeleceu para o jogo com relação a pontuação final.

Ganha o jogo a equipe que tiver a pontuação final exatamente igual a 100 pontos. Não havendo equipes que atingiram essa pontuação exata, vence a equipe que se aproximar mais dos 100 pontos. As demais regras, permanecem iguais e cada grupo recebe uma nova folha de registro, na qual anotará os pinos derrubados e pontuações do segundo momento. 


\section{Boliche matemático $-2^{\circ}$ momento}

Alunos (grupo):

Nessa tabela você irá marcar a quantidade de pinos derrubados em cada rodada e escolher o valor de cada rodada (dobro, triplo ou quíntuplo) para obter a pontuação final estipulada.

\begin{tabular}{|c|c|c|c|c|c|}
\hline \multicolumn{2}{|c|}{ RODADA DO } & \multicolumn{2}{|c|}{ RODADA DO } & \multicolumn{2}{|c|}{ RODADA DO } \\
\hline Jogador 1 & Pinos & Jogador 1 & Pinos & Jogador 1 & Pinos \\
\hline Jogador 2 & Pinos & Jogador 2 & Pinos & Jogador 2 & Pinos \\
\hline Jogador 3 & Pinos & Jogador 3 & Pinos & Jogador 3 & Pinos \\
\hline Jogador 4 & Pinos & Jogador 4 & Pinos & Jogador 4 & Pinos \\
\hline \multicolumn{2}{|c|}{ Quantidade total de pinos } & \multicolumn{2}{|c|}{ Quantidade total de pinos } & \multicolumn{2}{|c|}{ Quantidade total de pinos } \\
\hline \multicolumn{2}{|c|}{ Pontos totais da rodada } & \multicolumn{2}{|c|}{ Pontos totais da rodada } & \multicolumn{2}{|c|}{ Pontos totais da rodada } \\
\hline
\end{tabular}

Pontuação final do jogo:

Pontuação final estipulada:100 pontos

Conclusões:

Figura 4.2: Folha de Registro Boliche Matemático - $2^{\circ}$ momento

Realiza-se uma segunda roda de conversa com os estudantes, na qual eles discutem como foi feita a escolha das rodadas neste segundo momento, para que se atinjam os 100 pontos. Além disso, discute-se também as diferenças entre o primeiro e segundo momento da atividade Boliche matemático. 


\subsubsection{Trilha das Leis}

Para esta atividade, os estudantes são organizados em grupos de 4 pessoas. Cada grupo recebe um kit contendo o material para o jogo: tabuleiro, dado, pinos para marcar a posição no jogo, cartas com as funções escritas por extenso, folha de registro individual (uma para cada estudante).

Embaralha-se as cartas e as colocam com a parte escrita virada para baixo, de forma que o jogador não identifique qual carta irá sortear.

\begin{tabular}{|c|c|c|}
\hline $\begin{array}{l}\text { Ande o número de } \\
\text { casas que você firou } \\
\text { mais uma! }\end{array}$ & $\begin{array}{l}\text { Ande o número de } \\
\text { casas que você firou } \\
\text { menos uma! }\end{array}$ & $\begin{array}{l}\text { Ande o número de } \\
\text { casas que você firou! }\end{array}$ \\
\hline $\begin{array}{c}\text { Ande o dobro de casas } \\
\text { que você firou! }\end{array}$ & $\begin{array}{c}\text { Ande o dobro de casas } \\
\text { que você tirou menos } \\
\text { uma! }\end{array}$ & $\begin{array}{c}\text { Ande o dobro de casas } \\
\text { que você firou mais } \\
\text { uma! }\end{array}$ \\
\hline $\begin{array}{c}\text { Ande o dobro de casas } \\
\text { que você firou menos } \\
\text { duas! }\end{array}$ & $\begin{array}{c}\text { Ande o dobro de casas } \\
\text { que você firou mais } \\
\text { duas! }\end{array}$ & $\begin{array}{c}\text { Ande o dobro de casas } \\
\text { que você firou mais } \\
\text { frês! }\end{array}$ \\
\hline $\begin{array}{c}\text { Ande o friplo de casas } \\
\text { que você firou menos } \\
\text { frês! }\end{array}$ & $\begin{array}{c}\text { Ande ofriplo de casas } \\
\text { que você firou menos } \\
\text { duas! }\end{array}$ & $\begin{array}{c}\text { Ande ofriplo de casas } \\
\text { que você firou menos } \\
\text { uma! }\end{array}$ \\
\hline $\begin{array}{c}\text { Ande o friplo de casas } \\
\text { que você firou! }\end{array}$ & $\begin{array}{c}\text { Ande ofriplo de casas } \\
\text { que você tirou mais } \\
\text { uma! }\end{array}$ & $\begin{array}{c}\text { Ande o friplo de casas } \\
\text { que você firou mais } \\
\text { duas! }\end{array}$ \\
\hline $\begin{array}{c}\text { Ande o quádruplo de } \\
\text { casas que você firou } \\
\text { menos frês! }\end{array}$ & $\begin{array}{c}\text { Ande o quádruplo de } \\
\text { casas que você firou } \\
\text { menos duas! }\end{array}$ & $\begin{array}{c}\text { Ande o quádruplo de } \\
\text { casas que você firou } \\
\text { menos uma! }\end{array}$ \\
\hline $\begin{array}{l}\text { Ande o quádruplo de } \\
\text { casas que você firou! }\end{array}$ & $\begin{array}{l}\text { Ande o quádruplo de } \\
\text { casas que você firou } \\
\text { menos quafro! }\end{array}$ & $\begin{array}{c}\text { Ande o número de } \\
\text { casas que você firou } \\
\text { mais uma! }\end{array}$ \\
\hline
\end{tabular}

Figura 4.3: Cartas com as funções para a atividade Trilha das Leis 
Posiciona-se os pinos na casa saída, que indica o início do jogo. Os 4 estudantes de cada grupo lançam os dados e o que sortear o maior número dará início ao jogo, seguindo a ordem decrescente para os demais. Vence o jogo o primeiro estudante que alcançar a casa chegada.

O estudante que dará início ao jogo deverá lançar o dado e logo em seguida retirar a primeira carta do monte. Ele deve ler a carta em voz alta para que os outros três integrantes do grupo possam ouvir,calcular e conferir a movimentação do pino no jogo. O estudante deve obedecer a lei contida na carta, utilizando a numeração sorteada nos dados como referência para efetuar os cálculos. Por exemplo, se um estudante sorteia o número 3 no dado, e tira a carta "Ande o número de casas que você tirou menos uma", logo, esse estudante irá avançar 3 - 1 casas, ou seja, 2 casas.

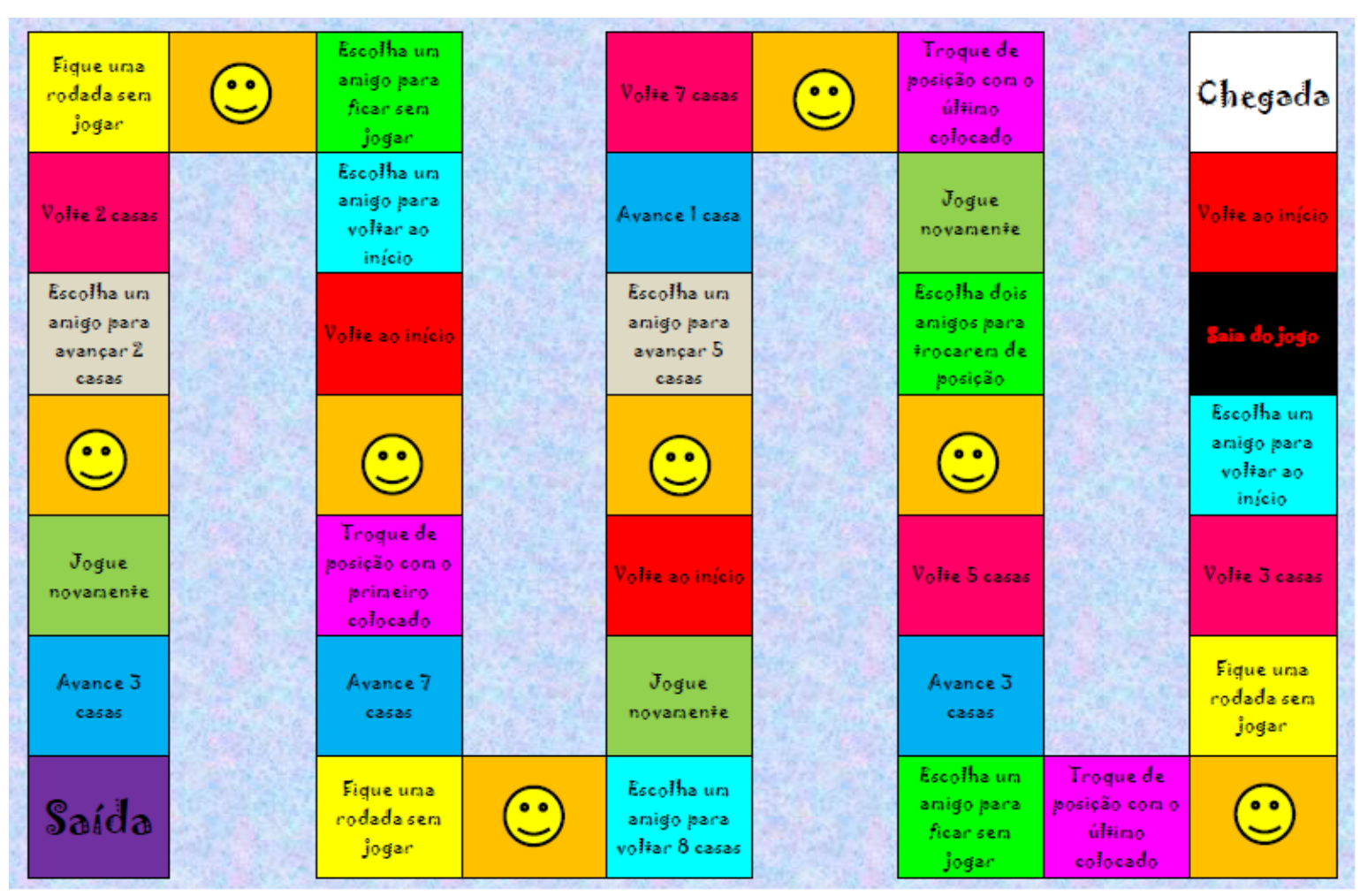

Figura 4.4: Tabuleiro da atividade Trilha das Leis 
Cada estudante do grupo recebe uma folha de registro própria, conforme a figura a seguir, na qual anota o número sorteado no dado, a "lei" contida na carta que foi retirada e a quantidade de casas avançadas.

Trilha das leis

Jogador:

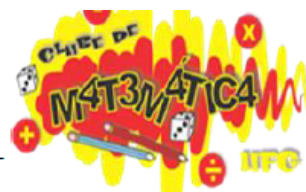

\begin{tabular}{|l|l|l|}
\hline $\begin{array}{c}\text { Número Sorteado nos } \\
\text { Dados }\end{array}$ & Lei & $\begin{array}{c}\text { Quantas casas } \\
\text { andei ? }\end{array}$ \\
\hline & & \\
\hline & & \\
\hline & & \\
\hline & & \\
\hline & & \\
\hline & & \\
\hline
\end{tabular}

Figura 4.5: Folha de registro da atividade Trilha das Leis

É interessante que o professor dialogue com os estudantes sobre a atividade realizada, a relação entre as cartas e o número sorteado no dado e a quantidade de casas avançadas, a forma como os alunos escreveram ou representaram as "leis" contidas nas cartas, entre outros questionamentos que irão surgir a partir destes, relacionados à atividade e ao ensino de álgebra. 


\subsubsection{Batalha Naval}

Os estudantes são divididos em dois grupos, cada grupo recebe um campo de batalha e uma folha de registro para anotar as suas jogadas. O campo de batalha contém coordenadas cartesianas compostas por letras e números, por exemplo: A2 , em que a letra A indica uma coluna e o número 2 indica a linha.

Tabuleiro Batalha Naval

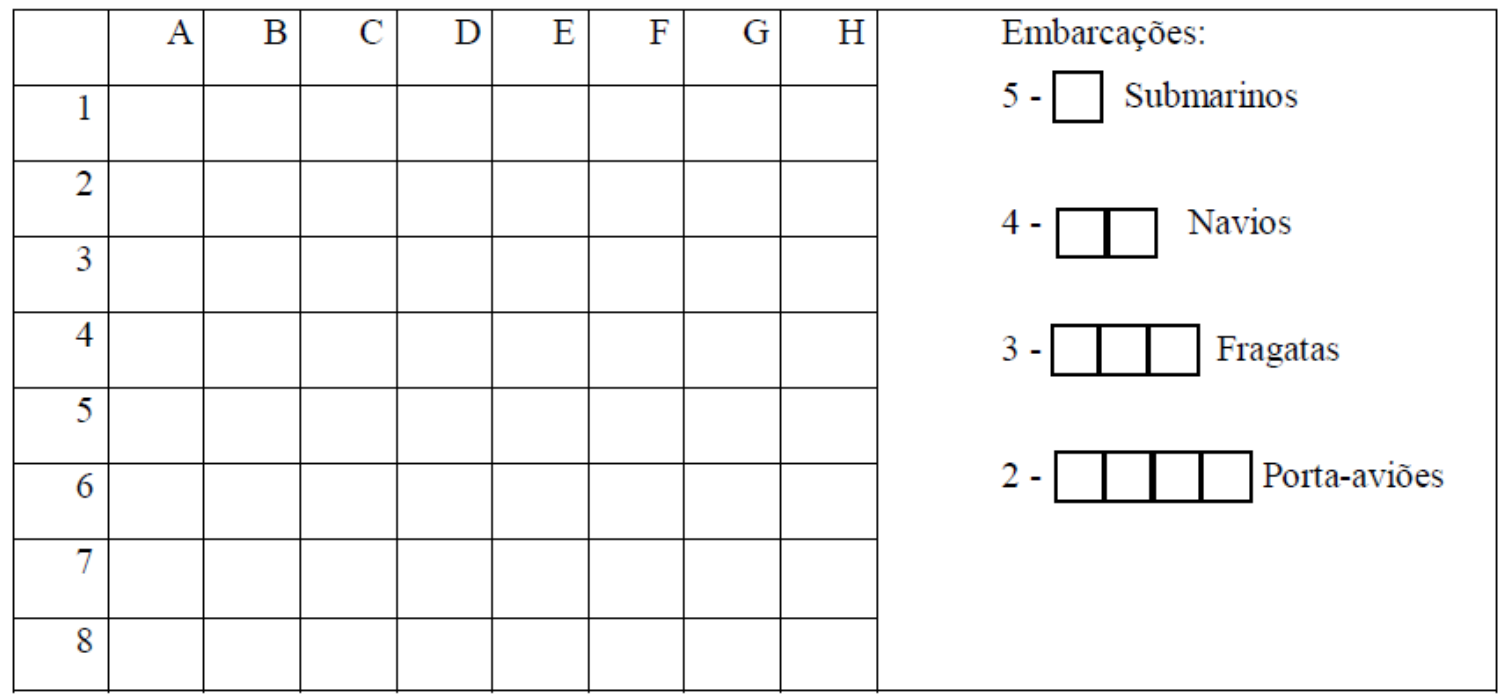

Figura 4.6: Campo de batalha da atividade Batalha Naval

No campo de batalha o grupo fará seu jogo, posicionando suas embarcações (cinco submarino, quatro navios, três fragatas e dois porta-aviões em cada planilha). Depois que os grupos posicionarem as embarcações nos campos de batalha menores, entregarão ao o professor para que este mantenha o controle das jogadas, nos dois campos de batalha maiores, feitos com cartolina e anexados em algum lugar visível para todos os estudantes que participam da atividade.

O objetivo do jogo, assim como no jogo tradicional de batalha naval, é que cada grupo encontre e "afunde" as embarcações do grupo adversário. Porém, nessa atividade, diferentemente do jogo tradicional, há uma correspondência entre as linhas e colunas do campo de batalha. O grupo fala uma coordenada e o professor utiliza correspondência entre linhas e colunas para identificar qual coordenada será atingida no campo de batalha. 


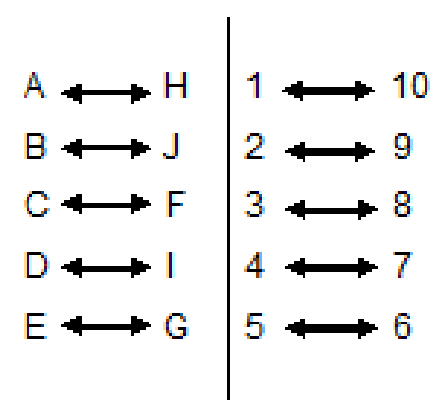

Figura 4.7: Exemplo de correspondência Campo de Batalha

Por exemplo, quando os estudantes escolhem a coordenada A-2, a jogada é direcionada para H-9. O professor marca a posição A-9 e os estudantes devem se atentar para essa correspondência, afim de acertarem os alvos desejados. Para auxiliálos, há uma folha de registros na qual os estudantes marcam as jogadas realizadas durante o jogo.

Ao final do jogo, os estudantes utilizam o registro para concluir a atividade. Neste momento discute-se a importância de descobrir a relação de correspondências entre as linhas e colunas, para que os grupos pudessem direcionar e "afundar" as embarcações adversárias. 
Capítulo 4. A relevância da experiência no processo de ensino e aprendizagem de matemática.

Batalha Naval

Nome dos Tripulantes:

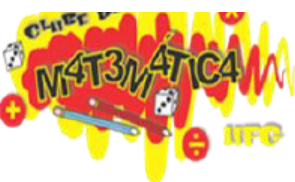

\begin{tabular}{|c|c|c|c|}
\hline \multicolumn{4}{|c|}{ Diário da Batalha } \\
\hline \multicolumn{2}{|c|}{ O que falamos? } & \multicolumn{2}{|c|}{ Onde Caiu? } \\
\hline Letra & Número & Letra & Número \\
\hline & & & \\
\hline & & & \\
\hline & & & \\
\hline & & & \\
\hline & & & \\
\hline & & & \\
\hline & & & \\
\hline & & & \\
\hline & & & \\
\hline & & & \\
\hline & & & \\
\hline & & & \\
\hline & & & \\
\hline & & & \\
\hline & & & \\
\hline & & & \\
\hline & & & \\
\hline & & & \\
\hline & & & \\
\hline Conclusão: & & & \\
\hline & & & \\
\hline
\end{tabular}

Figura 4.8: Folha de registro da atividade Batalha Naval

Essas três atividades expostas foram escolhidas para compor esse trabalho, tendo em vista o referencial bibliográfico que atentou-nos para três aspectos principais: as dificuldades dos estudantes com relação aos dos conteúdos algébricos, a necessidade dos professores de troca de experiências e de instrumentos que possam facilitar a introdução e ensino desses conteúdos, e por último a carência de pesquisas relacionadas especificamente à expressões algébricas.

Notamos, a partir dos referenciais bibliográficos, que, os estudos relacionados às 
Capítulo 4. A relevância da experiência no processo de ensino e aprendizagem de matemática.

equações e funções tem sido abordados com maior frequência pelas pesquisas, enquanto os conceitos iniciais de variável e expressões, embora primordiais são menos recorrentes entre os autores que trabalham os conteúdos algébricos visando o Ensino Fundamental Anos Finais.

Dessa forma, partimos em busca da construção de um processo metodológico que nos permitisse discutir tais temas e alcançar o objetivo de validação das atividades. 


\section{Capítulo 5}

\section{Método}

Não é tarefa simples conceituar pesquisa qualitativa, uma vez que essa área passa por constantes processos de (re)elaboração. Utilizaremos alguns aspectos enumerados por Borba (2004) nos quais uma pesquisa qualitativa deve se reconhecer:

- Transitoriedade de seus resultados;

- A impossibilidade de uma hipótese a priori, cujo objetivo da pesquisa será comprovar ou refutar;

- A não neutralidade do pesquisador que, no processo interpretativo, se vale de suas perspectivas e filtros vivenciais prévios dos quais não consegue se desvencilhar;

- Que a constituição de suas compreensões dá-se não como resultado, mas numa trajetória em que essas mesmas compreensões e também os meios de obtê-las podem ser (re)configurados;

- A impossibilidade de estabelecer regulamentações, em procedimentos sistemáticos, prévios, estáticos e generalistas.

Borba (2004) afirma que são influências diretas na pesquisa a forma como o pesquisador concebe a Matemática, a Educação Matemática, o Conhecimento e como ele é produzido.

No nosso caso, entendemos conhecimento como resultado da interação entre o coletivo pensante e suas experimentações com o objeto. Logo, construímos as informações para análise dessa pesquisa por meio do desenvolvimento de situações em grupo, nas quais foram consideradas ações, oralidade e escrita. Elaboramos situações nas quais os professores, se colocaram no papel de estudantes, participando da investigação e da formulação de hipóteses que foram partilhadas, analisadas e discutidas pelo grupo. 
Para o desenvolvimento da pesquisa foi fundamental a colaboração dos professores, tendo em vista o caráter voluntário de suas participações. Neste momento é interessante ressaltar que compreendemos colaboração, a partir da perspectiva proposta por Fiorentini (2004), como um processo no qual

[...]todos trabalham conjuntamente (co-laboram) e se apoiam mutuamente, visando atingir os objetivos comuns negociados pelo coletivo do grupo. Na colaboração, as relações, portanto, tendem a ser nãohierárquicas, havendo liderança compartilhada e co-responsabilidade pela condução das ações. (p.50).25]

Ponte e Boavida(2002) 9] afirmam "colaboração não é um fim em si mesma mas sim um meio para atingir certos objectivos". Para esses autores "[..] o simples facto de diversas pessoas trabalharem em conjunto não significa que se esteja, necessariamente, perante uma situação de colaboração". Afirmam, ainda, que, a utilização do termo colaboração é adequado nos casos em que os indivíduos trabalham conjuntamente, sem relação hierárquica, a partir de uma perspectiva "de igualdade de modo a haver ajuda mútua e a atingirem objectivos que a todos beneficiem".

As características de liderança compartilhada, apoio e respeito mútuo fortalecem nos participantes a sensação de serem de fato membros da pesquisa, fazendo-se compreender a necessidade de se construir coletivamente caminhos que levarão aos resultados, atendendo não apenas os objetivos da pesquisadora, mas também os objetivos de todo o grupo que compõe e vivencia a pesquisa.

Pimenta, Garrido e Moura (2001)[51] denominam pesquisa-ação-colaborativa a pesquisa cuja metodologia busca "criar uma cultura de análises práticas nas escolas, tendo em vista suas transformações pelos professores, com a colaboração dos professores universitários". Portanto, compreendemos que a pesquisa-ação colaborativa deixa de ser pesquisa sobre os professores para tornar-se pesquisa com professores, aproximandose da compreensão de Fiorentini (2004) por pesquisa colaborativa.

A forma como o grupo de professores participantes dessa pesquisa foi constituído, foi determinante para o desenvolvimento do trabalho, para a promoção das reflexões e processos de investigação. Afinal, os professores interessados em participar das pesquisas relacionadas aos processos de ensino e aprendizagem, demonstraram que há preocupação com o desenvolvimento profissional e também com sua prática em sala de aula.

Por meio do trabalho colaborativo, chegamos ao processo de validação das atividades. A proposta de trabalho, permitiu que os professores participantes da pesquisa, assumissem o papel de estudantes e experimentassem as atividades a partir dessa condição. Entendemos que os professores, não se desligaram completamente de 
sua realidade, ao se posicionarem como estudantes, todavia tentamos aproximá-los ao máximo da realidade vivenciada pelos estudantes nas salas de aula.

Analisamos as três atividades propostas, apreciando cada uma delas, por meio de um conjunto de etapas: design, funcional, desenvolvimento e análise pedagógica, visando-se chegar a um conceito à respeito de cada atividade vivenciada.

Nesse sentido, é importante uma breve discussão a cerca da validação das atividades propostas durante o desenvolvimento dessa pesquisa. A palavra validação vem do Latim validare, que significa fortificar, fortalecer, bem como, tornar algo legítimo, fazer com que se torne válido a partir das regras em vigor. Entendemos como um conjunto de procedimentos, por meio dos quais se atribui concepção ao objeto estudado, logo, o que fizemos nesse trabalho foi conceituar e comprovar a legitimidade das atividades de ensino apresentadas, como mais uma ferramenta para o ensino e aprendizagem de expressões algébricas, com possibilidades de exploração de outros conteúdos matemáticos.

Machado(2013), em seu trabalho, intitulado $A$ confecção e validação de jogos para o ensino de geometria no ensino médio: um desafio na formação de professores, ressalta a importância do processo de validação para análise do jogo proposto, afirmando que

[...]em relação à confecção dos jogos, pode-se inferir que o processo de validação do jogo é importante para que não passe despercebido alguns erros presente no mesmo, principalmente nas regras. Destacamos nesse processo, o quanto foi importante não só jogar com os colegas e verificar as regras, como também a confecção do material, pois se o jogo tiver algo duvidoso, o estudante pode não assimilar o conteúdo e o mesmo não será valioso para a sua aprendizagem. Além disso, o material da confecção também tem que ser testado. (p.6).41]

Nesse trabalho validamos as atividades de ensino, a partir das experiências vivenciadas pelos professores, durante a sessão com a pesquisadora. Os mesmos experimentaram cada atividade, jogando, respondendo os registros, testando as regras e a aplicabilidade de cada atividade.

Optamos por desenvolver a pesquisa junto a professores por compreendermos a relevância dessa interação para o processo formativo. A sessão desenvolvida nesse trabalho, constituiu-se em um espaço de reflexão e de análise das práticas pedagógicas desenvolvidas em salas de aula, e também em um momento de trocas de saberes, no qual o professor foi protagonista do próprio processo de formação.

Entendemos que diante da exaustiva carga horária do professor, com uma quantidade excessiva de aulas e tarefas burocráticas, esses momentos de diálogo com os outros profissionais, são compreendidos como privilégio. Afinal, ao compartilhar com 
os demais sua própria experiência, o professor passa por um intenso movimento de reflexão sobre a própria prática.

Ao considerarmos as concepções e trocas realizadas pelos mesmos com relação as atividades de ensino, reforçamos a credibilidade da pesquisa qualitativa, atingindo não só os objetivos da pesquisadora, mas de aprendizagem e troca entre os participantes e da pesquisa como um todo.

Assim, a pesquisa foi divida em quatro momentos:

- $1^{\mathrm{O}}$ momento - elaboração do projeto, pesquisa e leitura das bibliografias

- $2^{\circ}$ momento - organização das atividades de ensino socializadas com os professores

- $3^{\circ}$ momento - encontro com os professores, o que denominaremos "sessão", para aplicação das atividades de ensino.

- $4^{\mathrm{o}}$ momento - análise dos resultados e conclusão.

A primeira sessão com os professores contou com a presença da pesquisadora e da assistente de filmagens. Os professores convidados são oriundos da rede pública de ensino e já atuaram ou atuam no Ensino Fundamental Anos Finais na Secretaria de Estado e Educação do Distrito Federal (SEE-DF) $)^{1}$.

Essa sessão foi dividida em três momentos:

- $1^{\circ}$ momento - recepção dos professores e diálogo visando a integração

- $2^{\circ}$ momento - aplicação das atividades de ensino. Os professores assumiram papel similar ao dos estudantes.

- $3^{\circ}$ momento - os professores participantes da pesquisa dialogaram sobre as atividades vivenciadas. Analisando-as e percebendo suas potencialidades e limitações com relação a abordagem do conteúdo curricular e aplicabilidade em sala de aula, discutindo, adaptando, reconstruindo e validando as atividades de ensino.

Nestes momentos a pesquisadora assumiu o papel mediador entre professores e objeto, apresentando-lhes as atividades e fazendo as interferências necessárias para o desenvolvimento da sessão e da pesquisa. Durante a sessão, foram feitas filmagens e recolhimento dos registros relevantes para a pesquisa e para a construção das informações da mesma. Optamos por utilizar as filmagens, tendo em vista o seu potencial de transformação para a pesquisa em Educação Matemática.

\footnotetext{
${ }^{1}$ Site: http://www.se.df.gov.br/ acesso em 10 julho 2016.
} 
Powell (2015), a partir de suas observações no cenário nacional, aponta que ainda há poucas publicações sobre o uso de vídeos para produção e análise de pesquisas em Educação Matemática, e essa carência é ainda maior quando se trata da forma de analisar e tratar metodologicamente as informações construídas através das filmagens, tendo em vista a grande quantidade de materiais que são construídos.

As informações para análise não se restringem apenas às transcrições das falas, mas aos gestos e expressões do interlocutor, o tom de voz utilizado, sua posição no espaço físico diante do grupo para o qual fala, entre outros aspectos. Logo, ao mesmo tempo que as filmagens nos permitem riquezas e ganhos significativos diante de uma avaliação qualitativa, também é desafiadora no sentindo da escolha de uma metodologia que contribua para uma abordagem e análise coerente e conveniente das informações construídas. Powel(2015) considera que,

[...]em suma, o que podemos observar na literatura, nacional e internacional, é que o vídeo é uma ferramenta que oferece possibilidades em diferentes, alguns diriam incomensuráveis, orientações metodológicas. Estas incluem a etnografia, a etnometodologia, a experimentação, a análise do discurso, a análise de interação, entre outras. No entanto, independentemente da orientação metodológica de um pesquisador ou de metas específicas de investigação, o vídeo oferece um meio de documentação e observação de perto e apresenta inéditas possibilidades analíticas, colaborativas e de arquivo, bem como novos problemas de pesquisa. (p.25). 54

Os vídeos nos possibilitam registrar comportamentos e interações mais complexas, que provavelmente não seriam explicitados por meio de outros instrumentos usados mais frequentemente para construção das informações da pesquisa em Educação Matemática, além disso, possibilitam rever as atividades, analisando de forma mais cuidadosa, evitando precipitações nas interpretações, e principalmente concedem ao pesquisador a oportunidade de interagir durante a pesquisa, com participantes e objeto, e posteriormente, vivenciar essa interação, porém, como espectador.

A grande quantidade de informações construídas durante as gravações pode representar uma dificuldade na proposta de análise da pesquisa, por isso Powell (2015) propõe uma importante discussão a respeito do tratamento e análise de informações obtidas por meio desse recurso.

A transcrição das informações deve acontecer focada no objeto de investigação, percorrendo e discutindo as hipóteses propostas pela pesquisa. Logo, o recorte é feito com base nas questões apresentadas no trabalho, e também pautados nos objetivos da pesquisa.

Nesse caso, utilizamos a proposta de Powell (2015), para os processos de transcrição, associando os eventos relevantes que, posteriormente foram analisados pela 
pesquisadora, denominados por Powell "eventos críticos", aos comentários e descrições que possibilitem ao leitor maior interação com o texto, vislumbrando uma tentativa de vivência dos episódios filmados e explorados. A partir da proposta de Powell(2015), observamos que:

[...]um modo de realizar a apresentação dos dados é trazer, junto com a transcrição dos eventos críticos, uma descrição, para possibilitar que o leitor melhor compreenda as circunstâncias de cada fala. Desse modo, a transcrição dos eventos críticos e a descrição dos encontros, com circunstâncias das falas selecionadas para serem transcritas, comporão a apresentação dos dados, que também, por questões éticas, deve estar isenta de análise. O pesquisador deve possibilitar ao leitor uma visão crítica de sua análise, por meio de uma apresentação de dados que indica o que acontece no momento da pesquisa, e não o que o pesquisador interpreta que ocorre. Desse modo o leitor pode - e tem o direito de até não concordar com as conclusões da pesquisa. (p.34). 54]

Um dos principais exemplos da utilização de filmagens como recurso para a pesquisa em Educação Matemática, citados por Powell, foi o trabalho desenvolvido pelo Grupo colaborativo de Matemática (Grucomat) 2 grupo do qual Powell é um dos participantes. Esse grupo propõe a interação entre professores da educação básica, alunos da pós-graduação e professores da universidade. Segundo Powell(2015), o Grucomat

[...]constitui um espaço de reflexão; de análise das práticas desenvolvidas; de trocas de saberes; de compartilhamentos de dúvidas, incertezas e conquistas - enfim, um espaço em que nos (trans)formamos e nos constituímos profissionalmente. (p.70). [54]

A sessão e as informações construídas para a análise desse trabalho são apresentados de forma descritiva, além de fazermos interlocuções com análises e inferências afim de provocar reflexão e diálogo com o leitor. Afinal, entendemos que a pesquisa voltada para o ensino não deve ser fechada, mas passível de mudanças, adaptações e interferências que contribuam para a aprendizagem e prática pedagógica do profissional da educação. Esperamos que esse trabalho seja mais uma semente e fomento, que gere inconformidade e construção de conhecimentos para muitas outras propostas relacionadas ao ensino de matemática.

\subsection{O cenário}

O cenário da pesquisa foi o Laboratório de Ensino de Matemática do Departamento de Matemática da Universidade de Brasília (LEMAT/UnB) ${ }^{3}$. Esse laboratório,

\footnotetext{
${ }^{2}$ Grupo criado em 2003, na Universidade São Francisco - campus de Itatiba, em princípio denominado Grucogeo (Grupo colaborativo em geometria). Site: http://grucomat.blogspot.com.br/, acesso em 21 maio 2016.

${ }^{3}$ Site do LEMAT-UnB: http://mat.unb.br/lemat/, acesso em 10 julho 2016.
} 
que esteve sob a coordenação da professora Ana Maria Redolfi de Gandulfo por muitos anos, tem sido construído e representa um importante espaço para a licenciatura e formação de professores no Departamento de Matemática da Universidade de Brasília $(\mathrm{MAT} / \mathrm{UnB})$.

O LEMAT-UnB é constituído por um espaço de formação, que realiza várias ações educativas, envolvendo alunos da graduação, professores atuantes no Ensino Fundamental e no Ensino Médio e alunos de escolas do Distrito Federal.

Além do espaço físico, contendo várias mesas grandes e cadeiras, o que permite a formar grupos para discussões e realização de outras atividades, o LEMAT contém vários materiais pedagógicos e manipuláveis relacionados ao ensino de matemática. Esses materiais são utilizados em oficinas e projetos desenvolvidos pelo laboratório.

O desenvolvimento de pesquisas, mini-cursos, oficinas, bem como a produção de artigos e participação em eventos, além do contato com professores e estudantes, induzem a uma constante busca e elaboração de materiais didáticos e novas propostas de ensino de matemática. Nesse sentido, o LEMAT se interessa pela experimentação de novas metodologias de ensino, tendo em vista a necessidade da formação continuada dos professores, que buscam partilhar, dialogar e superar as dificuldades relacionadas ao ensino de matemática, vivenciadas no dia a dia.

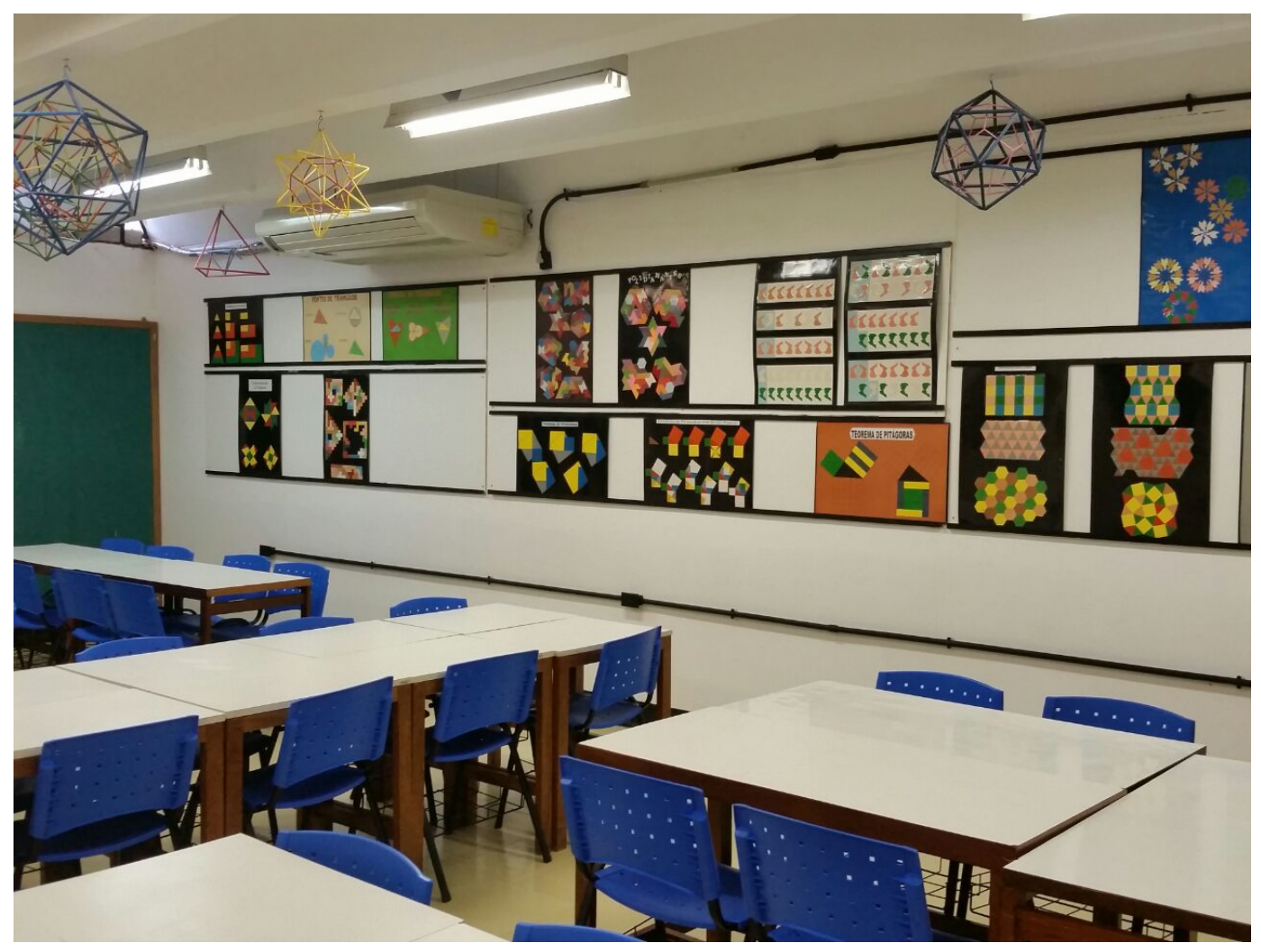

Figura 5.1: Foto do espaço LEMAT/UnB 
A seguir, apresentamos alguns materiais manipuláveis contidos no LEMAT/UnB. Lembramos que também existem outros materiais disponíveis no LEMAT. Para conhecê-los basta acessar o site 4 .

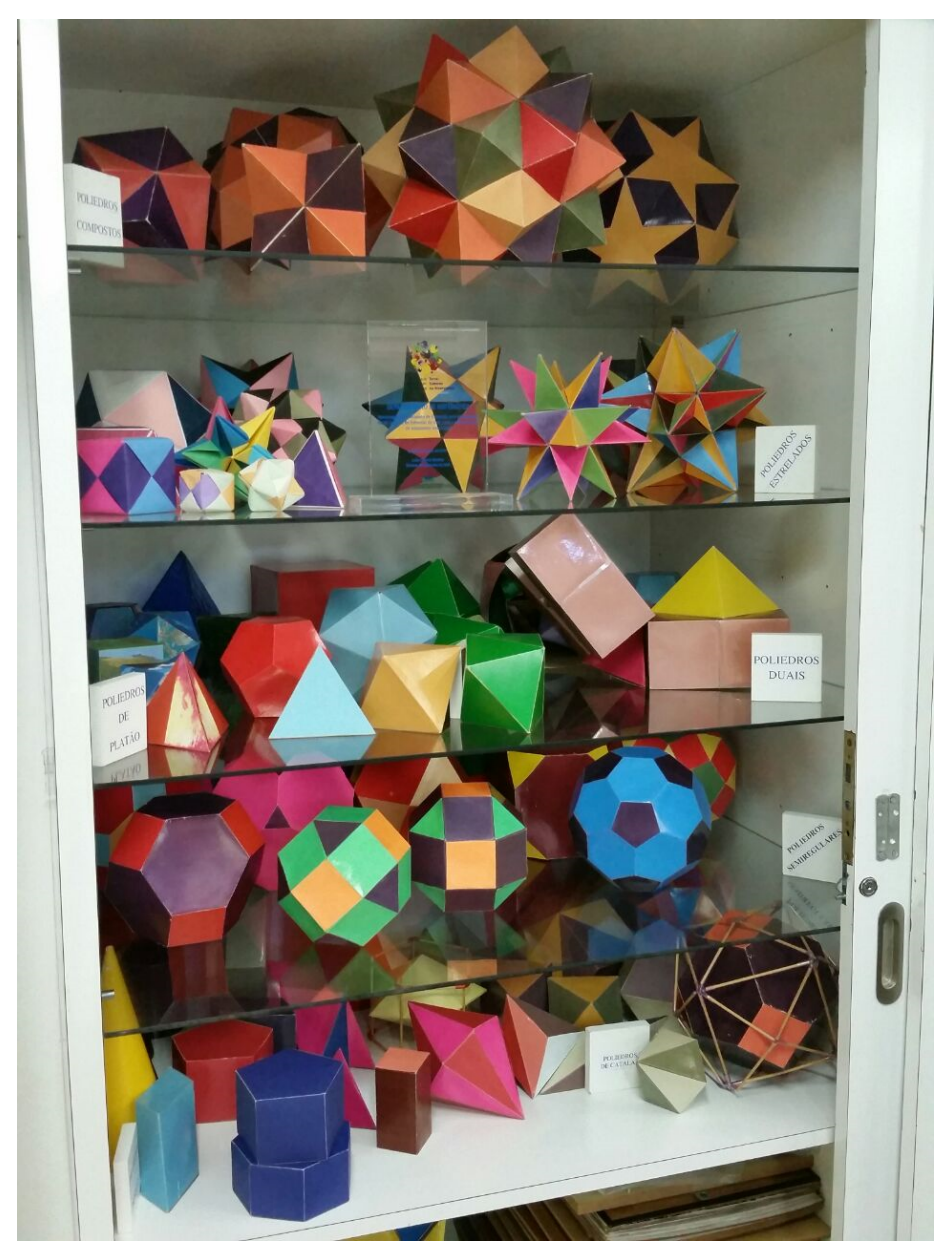

Figura 5.2: Alguns materiais manipuláveis do LEMAT/UnB

\subsection{Os participantes}

O grupo de participantes dessa pesquisa, foi composto por 8 professores que atuam em salas de aula do Ensino Fundamental e Ensino Médio de escolas públicas do Distrito Federal, ou ainda, em escolas particulares ou institutos federais. Referiremos aos participantes como: P1, P2, P3, P4 e P5 para os professores do gênero masculino e Pa1, Pa2 e Pa3, para o gênero feminino. É importante ressaltar que as letras não tem nenhuma associação aos nomes, escolas ou qualquer outro tipo de relação de identificação com os mesmos.

\footnotetext{
${ }^{4}$ http://mat.unb.br/lemat/26-2/. Acesso em 10 julho 2016.
} 
A pesquisadora convidou, via e-mail, alguns professores atuantes em escolas da rede pública do Distrito Federal e que mantinham elo com a UnB, uma vez que esse contato com a universidade pode indicar preocupação com a formação continuada. Os mesmos, dispuseram-se a participar da pesquisa de forma voluntaria, demonstrando bastante interesse em discutir o ensino e aprendizagem de álgebra, bem como partilhar suas experiências como profissionais atuantes na Educação Básica.

Entre os professores participantes da pesquisa, 5 são do gênero masculino e 3 do gênero feminino, com idades de 20 a 45 anos, sendo a maioria de 25 a 30 anos. Todos possuem a licenciatura em matemática, sendo que 5 cursaram em instituições públicas: 3 na Universidade de Brasília $(\mathrm{UnB})$; 1 na Universidade Federal de Goiás (UFG) e 1 na Universidade Federal do Rio Grande do Sul (UFRGS), e outros três em instituições particulares: 2 na Pontifícia Universidade Católica de Goiás (PUC GO) e 1 na Universidade Católica de Brasília (UCB). Cinco dos professores possuem título de Mestrado Profissional em Matemática e três estão com os cursos de mestrado em andamento.

Todos os participantes pertenciam ao quadro de professores efetivos da Secretaria de Estado de Educação, nas cidades Riacho Fundo II, Paranoá, Recanto das Emas, Asa Sul, Ceilândia, Gama, e Águas Claras, no entanto, durante o desenvolvimento da mesma, um dos professores passou a integrar o Instituto Federal de Educação, Ciência e Tecnologia de Goiás (IFG), no câmpus Valparaíso em Goiás. Em referência ao tempo de atuação, três dos professores aproximam-se de 5 anos de docência, enquanto outros 4 aproximam-se de 10 anos, e apenas um dos professores possui acima de 20 anos de docência.

Os professores atuam em salas de aula de ensino fundamental e médio, sendo 7 exclusivamente na rede pública, e entre eles um no Ensino Básico, Técnico e Tecnológico (EBTT), e 1 na escola particular e na rede pública, ao mesmo tempo. Desses participantes, 2 são professores apenas no ensino fundamental, 3 apenas no ensino médio, 2 nos ensinos fundamental e médio e 1 no ensino médio e superior.

Nossa proposta de trabalho incluiu uma sessão com os professores, com duração de 5 horas, na qual desenvolvemos as atividades. Não foi necessário a proposição de mais sessões. A pesquisadora, contactou os participantes anteriormente para informar qual era o tema da pesquisa, e também explicar que seriam desenvolvidas algumas atividades de ensino nesse encontro.

Todos os participantes encontraram-se no LEMAT da UnB, no primeiro semestre de 2016, para o desenvolvimento da pesquisa. Esse encontro contou também com a presença e o trabalho voluntário da assistente de pesquisa, que é professora e estudante do curso de pós graduação, envolvida com a pesquisa em ensino de matemática. A 
presença da assistente de filmagens não só permitiu uma despreocupação da pesquisadora com essa parte do trabalho, mas também possibilitou sua atuação, mediação e observação de forma mais efetiva no encontro.

\subsection{Instrumentos e Procedimentos}

Os instrumentos foram selecionados a partir dos objetivos propostos para esse trabalho. As informações construídas a partir de todo material analisado, nos permitiram uma proposta de pesquisa qualitativa.

Considerando os objetivos, os participantes e também o processo de construção das informações para a análise, dispomos no quadro a seguir os instrumentos utilizados para a realização da pesquisa. Para a construção do quadro, utilizaremos o modelo proposto por COSTA (2015, p.68).[19]

\begin{tabular}{l|l}
\hline Instrumentos e Procedimentos & Objetivos \\
\hline Questionário com as informações dos & $\begin{array}{l}\text { Caracterizar os participantes (sexo, } \\
\text { idade, formação acadêmica, instituição } \\
\text { participantes - } 1^{\mathrm{a}} \text { parte } \\
\text { na(s) qual(is) se formou, local de tra- } \\
\text { balho, nome da instituição na qual tra- } \\
\text { balha, cargo, descrição resumida da } \\
\text { função exercida, público com o qual o } \\
\text { trabalha). }\end{array}$ \\
\hline $\begin{array}{l}\text { Questionário com as informações dos } \\
\text { participantes - } 2^{\text {a parte }}\end{array}$ & $\begin{array}{l}\text { Inteirar-se das concepções dos professo- } \\
\text { res a partir da sua relação com a ma- } \\
\text { temática e com a álgebra enquanto alu- } \\
\text { nos, e relação com a matemática e com } \\
\text { a álgebra enquanto professores. }\end{array}$ \\
\hline $\begin{array}{l}\text { Revisão e preparo do material para } \\
\text { o encontro com os professores, e ela- } \\
\text { boração de um kit (caneta, pasta, } \\
\text { TCLE, cronograma das atividades, } \\
\text { mensagem de boas vindas) }\end{array}$ & $\begin{array}{l}\text { necessário para socializar e desenvolver } \\
\text { as atividades de ensino com os profes- } \\
\text { sores. }\end{array}$ \\
\hline Filmagens e transcrição & $\begin{array}{l}\text { Analisar o envolvimento e percepções } \\
\text { dos professores com relação ao desen- } \\
\text { volvimento das atividades de ensino, } \\
\text { bem como a mediação da pesquisa- } \\
\text { dora, para construção de informações } \\
\text { dessa pesquisa, buscando-se chegar à } \\
\text { validação das atividades de ensino. }\end{array}$ \\
\hline
\end{tabular}

Tabela 5.1: Instrumentos utilizados e objetivos da pesquisa 


\subsection{Questionário}

O questionárid $5^{5}$ foi divido em duas partes. A primeira parte possui perguntas mais objetivas, e caracteriza os professores quanto ao perfil social, voltadas para a formação acadêmica e profissional. A segunda parte, é voltada para as categorias de análise a serem utilizadas nessa pesquisa, e permite conhecer como era a relação dos participantes com a matemática e com a álgebra, enquanto alunos do ensino básico, e atualmente, como professores atuantes nesse segmento.

A primeira parte do questionário foi composta pelas seguintes indagações:

- Gênero

- Faixa etária

- Formação acadêmica

- Instituição na qual obteve a formação

- Região (local) de trabalho

- Instituição de trabalho

- Cargo dentro da instituição

- Descrição da função desenvolvida na instituição

- Público com o qual trabalha na instituição

$\mathrm{Na}$ tentativa de construir um segundo momento mais reflexivo e com menos limitações e de incitar os participantes a dialogarem de forma ainda mais reflexiva sobre sua relação com a matemática e álgebra, utilizamos os trabalhos de Fávero(2010a) e Fávero e Pina(2013) que propõem a elaboração de frases incompletas para serem completadas por participantes de uma pesquisa.

Nesse sentido, a segunda parte desse questionário foi composta por frases que foram completadas pelos participantes, de acordo com as suas vivências e relação com a matemática e a álgebra (enquanto alunos e também como professores da Educação Básica). Nesse momento, os participantes tiveram a oportunidade de se expressarem, tendo em vista que as frases os indagaram quanto às suas experiências, possivelmente, mais marcantes, levando-os a descrevê-las.

A segunda parte do questionário foi composta pelas seguintes indagações:

\footnotetext{
${ }^{5}$ Em anexo no final desse trabalho
} 
- Na minha história escolar a matemática...

- Na minha história escolar a álgebra....

- No meu percurso profissional - como professor(a) de matemática - a álgebra....

\subsection{Organização do material}

A partir da revisão bibliográfica, deu-se a seleção das atividades a serem propostas no encontro com os professores. Embora essas atividades já viessem sendo estudadas e exploradas, foi importante mais uma revisão de todo o material do projeto Clube de Matemática, desenvolvido pelo IME/UFG em parceria com o OBEDUC, e das produções e publicações mais recentes fundamentadas no Clube de Matemática.

Essas produções, durante todo o tempo, nortearam essa pesquisa, que inclusive pode ser encarada como uma proposta de continuidade dos trabalhos desenvolvidos pelo Clube de Matemática, porém com outra perspectiva, que é a da validação de atividades de ensino, a partir do olhar do professor atuante na Educação Básica.

Após a revisão bibliográfica das atividades de ensino, suas regras e registros, entre outros, deu-se início a construção dos tabuleiros e todo o material necessário para o desenvolvimento dessas atividades.

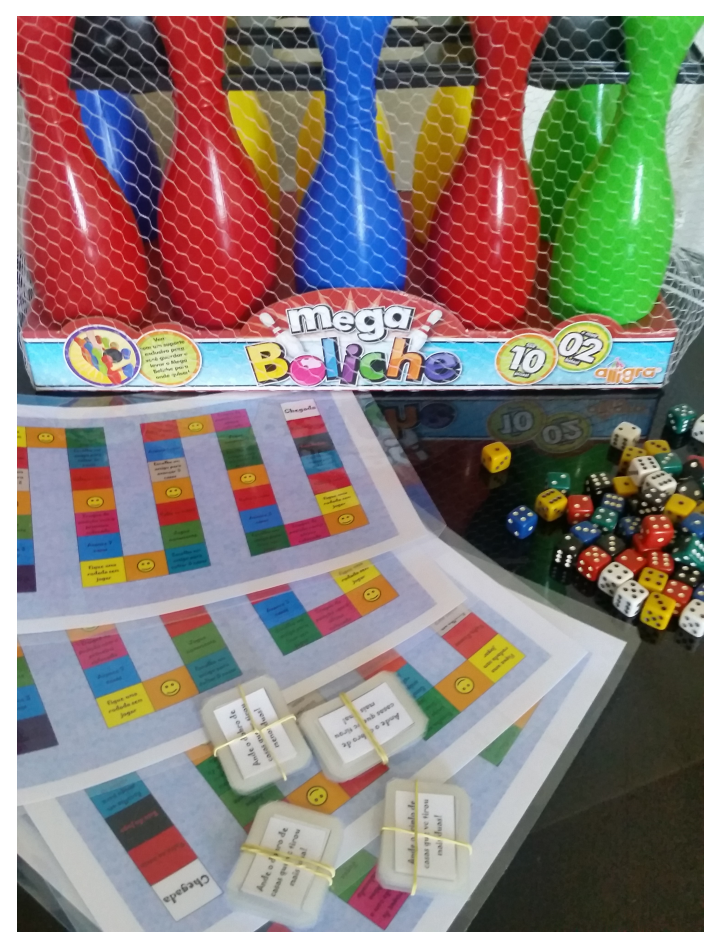

Figura 5.3: Materiais preparados para aplicação das atividades de ensino 
Além do material para as atividades, a pesquisadora fez uma pasta, contendo um kit para cada professor participante. Nesse kit havia: o TCLE, uma mensagem de boas vindas e agradecimentos pela colaboração, caneta, lápis, borracha e bloco de notas, ou seja, materiais de possível utilização durante a sessão.

Para a organização e orientação da sessão, propomos um cronograma que contava com as seguintes ações:

\begin{tabular}{l|l}
\hline Horário & Programação \\
\hline $8 \mathrm{~h}-9 \mathrm{~h}$ & Café da manhã \\
\hline $9 \mathrm{~h}-9 \mathrm{~h} 30$ & $\begin{array}{l}\text { Assinar o TCLE } \\
\text { Responder o questionário de identificação }\end{array}$ \\
\hline $9 \mathrm{~h} 30-10 \mathrm{~h} 30$ & $\begin{array}{l}\text { Apresentação das atividades de ensino: Boli- } \\
\text { che Matemático e Trilha das Leis }\end{array}$ \\
\hline $10 \mathrm{~h} 30-10 \mathrm{~h} 45$ & Intervalo \\
\hline $10 \mathrm{~h} 45-11 \mathrm{~h} 15$ & $\begin{array}{l}\text { Apresentação da atividade de ensino: Batalha } \\
\text { Naval }\end{array}$ \\
\hline $11 \mathrm{~h} 15-12 \mathrm{~h}$ & $\begin{array}{l}\text { Responder ao questionário sobre as atividades } \\
\text { de ensino desenvolvidas }\end{array}$ \\
\hline
\end{tabular}

Tabela 5.2: Programação da sessão realizada com os participantes da pesquisa.

Durante o desenvolvimento das atividades, e também no intervalo entre elas, os professores dialogaram e avaliaram as atividades e materiais. Logo, percebia-se que o processo de validação já estava acontecendo, antes mesmo de ser instigado pela pesquisadora, por meio da roda de conversa.

Entendemos roda de conversa como um dos instrumentos metodológicos para o levantamento de informações da pesquisa, que, segundo Melo e Cruz(2014) permite

[...]que os participantes expressem, concomitantemente, suas impressões, conceitos, opiniões e concepções sobre o tema proposto, assim como permite trabalhar reflexivamente as manifestações apresentadas pelo grupo. (p.32). 44]

A utilização da roda de conversa como metodologia, teve como objetivo possibilitar a socialização das experiências vivenciadas pelos professores e a troca de ideias, organizando um momento de reflexão e de pensar compartilhado. Iervolino e Pelicioni(2001 apud MELO, 2014) afirmam que a roda de conversa permite o diálogo entre participantes e pesquisador, de maneira coletiva. No entanto, não atenta para o fato de que não se trata de um processo "diretivo e fechado" mas de uma discussão direcionada, na qual debatem-se temas específicos, e os participantes têm a liberdade para emitir opiniões sobre os temas de seu interesse.

Nesse contexto, as opiniões costumam ter caráter qualitativo, principalmente por tratar-se de "falas" que ora podem ser consensuais e, em outros momentos, divergentes, dando continuidade ao debate. O pesquisador, que, na maioria das vezes, 
é o responsável por mediar os diálogos, deve garantir a todos o direito à expressão e participação igualitária, e ainda, organizar critérios que irão estruturar as discussões. Ademais, para a construção de informações e análise, a partir dos diálogos, utilizamos os recursos de filmagem e transcrição, contando com a indispensável colaboração da assistente de filmagens, que, foi responsável por parte das transcrições.

\subsection{Análise das informações}

Segundo Bardin (2011 apud COSTA, 2015) a análise de conteúdo, consiste em reunir técnicas que permitam identificar e explorar os principais conceitos de um texto. Ainda segundo esse autor, a análise do conteúdo

É um conjunto de instrumentos de cunho metodológico em constante aperfeiçoamento, que se aplicam a discursos (conteúdos e continentes) extremamente diversificados. (SILVA, 2013 apud BARDIN, 2011). 61]

A análise do conteúdo por Bardin (2011), divide-se em três momentos principais:

\begin{tabular}{l|l}
\hline Momentos & Descrição \\
\hline Pré-análise & $\begin{array}{l}\text { Nesse momento, o pesquisador sistematiza, realiza a leitura de } \\
\text { todo o material e escolhe quais documentos serão submetidos } \\
\text { à análise, além de construir proposições e hipóteses que serão } \\
\text { interpretadas, discutidas, refutadas ou validadas na fase final. } \\
\text { O pesquisador, consciente do material que será analisado e } \\
\text { também dos objetivos e hipóteses construídas, propõe alguns } \\
\text { indicadores que irão delinear a interpretação do material se- } \\
\text { lecionado. }\end{array}$ \\
\hline Exploração do \\
material & $\begin{array}{l}\text { É um momento de maior rigor, pois há um recorte das pala- } \\
\text { vras chaves, que por sua vez darão origem as categorias, or- } \\
\text { ganizando o material. "A exploração do material consiste na } \\
\text { construção das operações de codificação, considerando-se os } \\
\text { recortes dos textos em unidades de registros, a definição de re- } \\
\text { gras de contagem e a classificação e agregação das informações } \\
\text { em categorias simbólicas ou temáticas" (SILVA, 2013). [61] }\end{array}$ \\
\hline $\begin{array}{l}\text { Interpretação } \\
\text { dos resultados }\end{array}$ & $\begin{array}{l}\text { Nesse momento são abarcados tudo o que se diz respeito ao } \\
\text { tratamento dos resultados, inferências e interpretação. As } \\
\text { categorias são contrastadas e associadas à fundamentação } \\
\text { teórica do trabalho, produzindo conhecimento. }\end{array}$ \\
\hline
\end{tabular}

Tabela 5.3: Três momentos - Análise de conteúdo proposta por Bardin

Codificaçã $q^{6}$

\footnotetext{
${ }^{6}$ Bardin (1977 apud SILVA, 2013) define codificação como a transformação, por meio de recorte, agregação e enumeração, com base em regras precisas sobre as informações textuais, representativas
} 
OlIVEIRA(2003), afirma que o "objetivo da análise é perceber as regularidades e compreender os conceitos mais utilizados pelos participantes, tanto nos questionários como nos diálogos, explorando os significados e contextos nos quais esses conceitos estão inseridos, de forma intencional, sistematizando-os afim de construir resultados" (p.6). 50

Após a realização da sessão com os professores, deu-se início a análise das informações, organizando todo o material recebido por meio dos formulários, assistindo os vídeos, transcrevendo as informações construídas via questionário, e também inciando o processo de leitura da transcrição dos diálogos entre professores e pesquisadora.

A partir dessa primeira etapa, de leitura e análise das informações, dividimos os mesmos em categorias, afim de facilitar o tratamento.

A categorização gera classes que reúnem um grupo de elementos da unidade de registro. As classes são compiladas a partir da correspondência entre a significação, a lógica do senso comum e a orientação teórica do pesquisador.(OLIVEIRA, 2003, p.9). [50]

Dividir o trabalho em categorias é fundamental para tornar evidente o que é senso comum no grupo pesquisado e também fazer generalizações, tornado possível o processo de validação. Ressaltamos que a preocupação principal não está relacionada à descrição das informações, mesmo considerando essa etapa fundamental para a construção dos mesmas. Entendemos que, o maior desafio é produzir conhecimento a partir das informações analisadas.

Após a fase de categorização, partimos para uma construção mais direcionada, retomando a proposta, os objetivos e a bibliografia que fundamentam esse trabalho, fazendo as interpretações, inferências, refutando, implementando e validando as hipóteses.

$\overline{\text { das características do conteúdo (BARDIN }}, 2011$, p.4). 


\section{Capítulo 6}

\section{Construção das informações para a análise}

\subsection{Análise dos questionários}

Antes de partirmos para a análise, ressaltamos que a identificação recebida por cada professor, será a mesma utilizada nas respostas do questionário e na transcrição das falas.

A partir das informações consideradas para a análise, vimos que trata-se de um grupo com 5 professores e 3 professoras jovens, embora experientes, no qual a maioria possui idade compreendida entre 25 e 30 anos (4 professores). O restante do grupo, possui idade compreendida entre 20 e 25 anos (1 professor), 30 e 35 anos (1 professor), 35 e 40 anos (1 professor), 40 e 45 anos (1 professor).

Notamos que a faixa etária evidenciada na pesquisa, se aproxima do perfil dos professores do Distrito Federal, que assim como na maior parte do Brasil, se classifica como um perfil jovem. Segundo informações da Sinopse Estatística da Educação Básical1 de 2015, no Distrito Federal, há 30.241 professores em efetiva regência de classe na Educação Básica, dos quais 11.563 pertencem a faixa etária que varia de 30 a 39 anos, ou seja, um percentual próximo a 40\%. Se ampliamos essa faixa de 30 a 49 anos, esse número sobe para 21.373, alcançando um percentual maior que $70 \%$.

A sinopse relativa ao ano de 2007, possuiu grande riqueza ao construir e detalhar as informações para análise, e inclusive tornou-se objeto de estudo em separado para o Instituto Nacional de Estudos e Pesquisas Educacionais Anísio Teixeira (INEP). Logo, é válido ressaltar que em alguns momentos recorreremos também as informações

\footnotetext{
${ }^{1} \mathrm{O}$ Censo Escolar é um levantamento de dados estatísticos educacionais de âmbito nacional realizado todos os anos e coordenado pelo Inep. Os dados estatísticos são provenientes da Sinopse Estatística da Educação Básica 2015, elaborada a partir do Censo Escolar de 2015. Disponível em: http://portal.inep.gov.br/basica-censo-escolar-sinopse-sinopse. Acesso em 24 junho 2016. 33.
} 
evidenciadas nesse período.

O gráfico a seguir, corresponde a faixa etária dos professores da Educação Básica no DF, em 2007, segundo os dados do MEC22 de 2007.

\section{Comparativo da Proporção de Professores da Educação Básica por Faixa Etária, 2007}

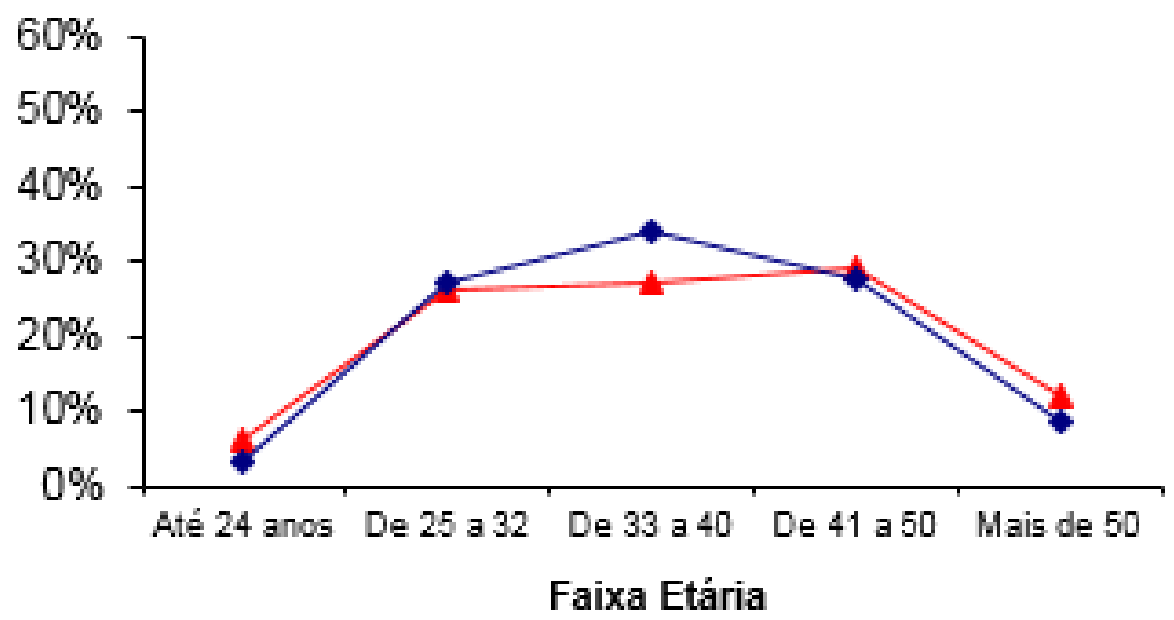

Fonte: MEC/Inep/Deed

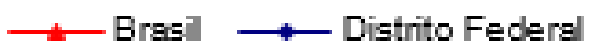

Figura 6.1: Faixa etária de professores da Educação Básica no DF, 2007.

Além da faixa etária, de modo geral, consideramos que a amostra contemplou os dois gêneros, atestando a tendência da inserção do gênero feminino na docência em matemática. FERNANDES (2006), considera que "em se tratando de docência em matemática no Ensino Médio, que historicamente era um espaço dominado pelos homens, aos poucos está sendo ocupado pelas mulheres no Sul e no Sudeste, enquanto nas demais regiões há um predomínio masculino"(p.34).[23]

Os professores são oriundos de escolas situadas nas seguintes regiões do DF: Riacho Fundo II, Paranoá, Recanto das Emas, Asa Sul, Ceilândia, Gama, Águas Claras, e um deles, que durante a pesquisa, migrou da SEE-DF para o Instituto Federal, trabalha em uma região do Entorno do DF, Valparaíso (GO). Observamos que os professores não tem um gasto de tempo excessivo quando se trata do transporte (o que poderia acarretar desgastes e estresse à sua rotina), uma vez que residem próximo ou na mesma região da escola.

Todos os professores possuem licenciatura em matemática, e 5 deles graduaramse em universidades públicas. Todos os participantes, inicialmente, pertenciam a SEE-

\footnotetext{
${ }^{2}$ Dados disponíveis no site: http://portal.mec.gov.br/plano-nacional-de-formacao-deprofessores/censo-do-professor. Acesso em 23 junho 2016.
} 
DF, e apenas um deles possui outro vínculo em uma escola particular. Durante a pesquisa, um dos professores passou a trabalhar exclusivamente em um instituto federal, deixando a SEE-DF.

Cinco professores possuíam mestrado, pois haviam concluído recentemente o curso Mestrado Profissional em Matemática em Rede Nacional; os outros três professores se encontravam com esse mesmo curso em andamento. Nesse sentido, percebemos que os professores demonstravam interesse pela formação continuada, e buscavam oportunidades e condições para realizá-la. Esse grupo, de certa forma, divergia-se do contexto dos professores da Educação Básica, que segundo os dados do INEP (Censo 2015), apenas 931 dos 30.241 professores Educação Básica, em efetiva regência, possuem mestrado.

Todos os professores pesquisados atuam na Educação Básica e já exerceram ou exercem regência no ensino fundamental. Atualmente, 4 professores atuam no ensino fundamental, e entre eles, 2 exclusivamente nesse nível de ensino. Outros três professores trabalham somente no ensino médio, e um professor na educação básica e tecnológica.

Como destacamos anteriormente, os professores participantes foram convidados a completar três frases assim organizadas:

1. Na minha história escolar a matemática...

2. Na minha história escolar com a álgebra...

3. No meu percurso profissional - como professor(a) de matemática, a álgebra...

No que se refere a frase número 1, os participantes manifestavam afinidade com a matemática. A maioria respondeu que "era a disciplina mais fácil" e uma de suas preferidas, enquanto outros utilizaram as palavras "interessante" e "agradável" para evidenciar sua afinidade com os conteúdos matemáticos. A seguir, a resposta do professor P4 ilustra como a maioria sentia-se com relação a aprendizagem de matemática.

1. Na minha história escolar a matemática...

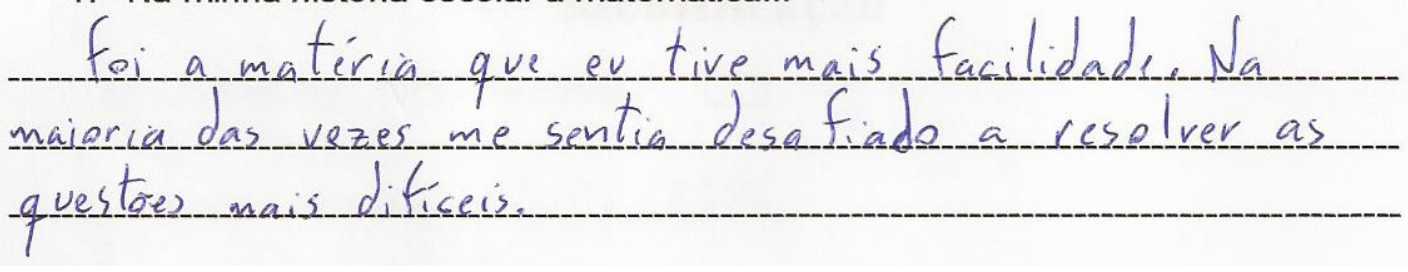

Figura 6.2: Resposta do P4 para o item 1 do questionário. 
A resposta desse professor também sugere que ao vivenciar a matemática, enquanto aluno, sentia-se desafiado. Outros participantes responderam de forma semelhante, mostrando que para eles era prazeroso sentirem-se desafiados e mantinham-se motivados ao superar esse desafio de compreender a matemática. Além disso, dois participantes responderam que percebiam-se privilegiados por compreender a matemática, evidenciando que ainda está presente o mito de que a matemática é uma ciência para um grupo seleto e superior intelectualmente.

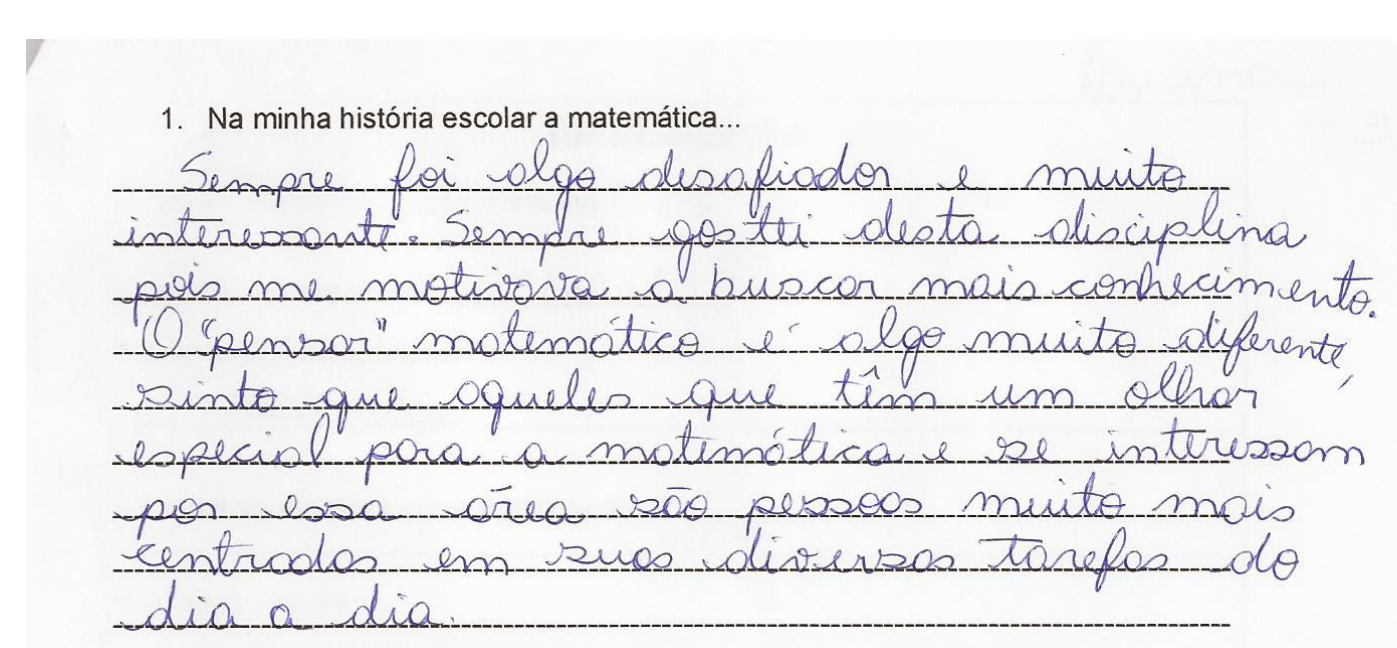

Figura 6.3: Resposta da Pa3 para o item 1 do questionário

Em algumas respostas, os participantes explicam que a relação prazerosa que mantinham ao aprender matemática não era vivenciada pela maior parte dos outros estudantes, e que de certa forma, eles se diferenciavam desses demais, justamente porque sua afinidade com a matemática era vista como "atípica" pelos colegas. Um dos professores respondeu que a matemática não parecia "agradável" para os seus colegas de classe, destacando o caráter "perverso" e "excludente" dessa disciplina.

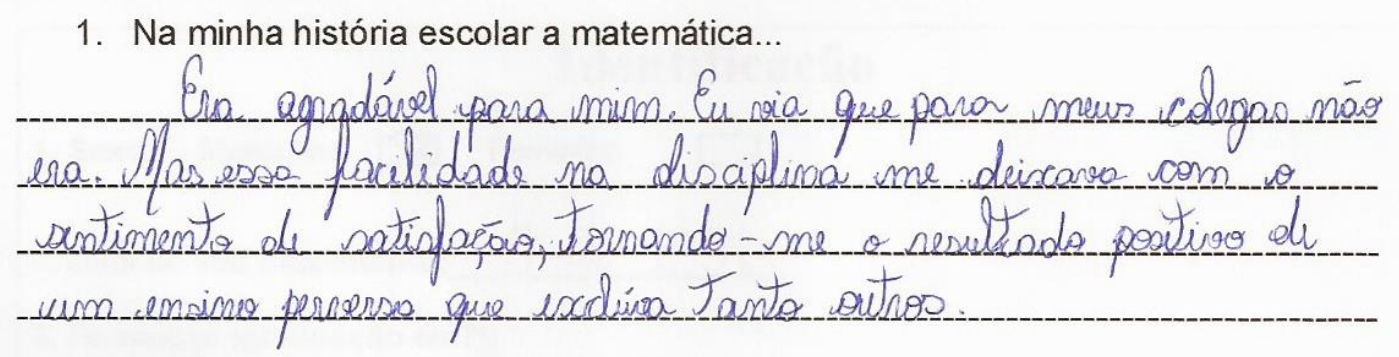

Figura 6.4: Resposta do P5 para o item 1 do questionário. 
Entendemos que a matemática muitas vezes é ensinada de forma mecânica e descontextualizada, o que provoca desestímulo e exclusão de parte dos estudantes. D'Ambrosio (2005 apud SILVA e SCHIRLO, 2008) afirma que:

A educação formal é baseada na mera transmissão de explicações e teorias (ensino teórico e aulas expositivas), no adestramento em técnicas e habilidades (ensino prático com exercícios repetitivos). Do ponto de vista dos avanços mais recentes de nosso entendimento dos processos cognitivos, ambas são totalmente equivocadas. Não se podem avaliar habilidades cognitivas fora do contexto cultural. (p.117). 62

O autor aponta (p.8) que o rompimento com o ensino tradicional e a aproximação com os contextos reais, permitem alcançar objetivos mais satisfatórios para a realidade vivenciada. Ainda, de acordo com D’Ambrosio (1986) é inaceitável que a matemática seja "transmitida" de forma dissociada das aplicações práticas, e que não represente progresso no que se diz respeito à melhora da qualidade de vida do ser que aprende.

A resposta do professor P2 propõe a associação dos conteúdos matemáticos às vivências do dia a dia, aplicados a outros contextos, com o objetivo de facilitar a compreensão dos conceitos.

1. Na minha história escolar a matemática...

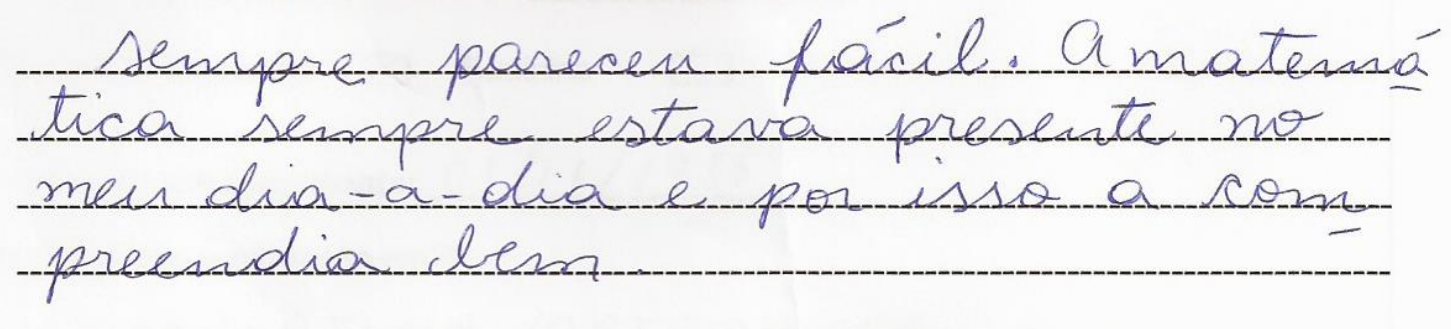

Figura 6.5: Resposta do P2 para o item 1 do questionário. 
No que se refere a frase número 2, os participantes caracterizam a álgebra como uma ferramenta para a resolução de problemas, principalmente os "mais difíceis", que não possuíam solução aparentemente imediata. O professor P1 destaca que a álgebra "estudada sem aplicabilidade, era chato e sem sentido".

2. Na minha história escolar a álgebra....

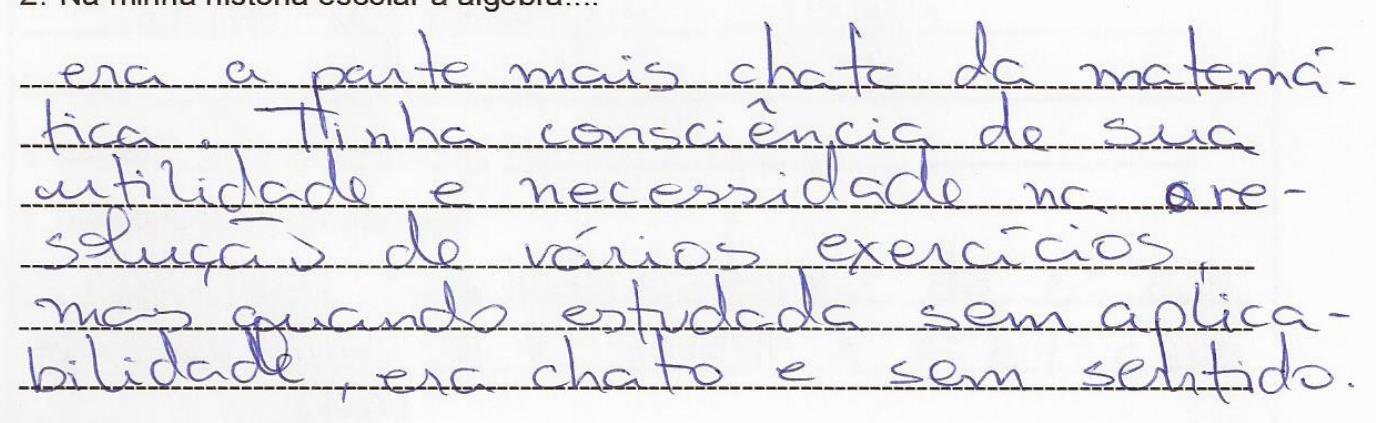

Figura 6.6: Resposta do P1 para o item 2 do questionário.

É comum em nossas salas de aula os alunos questionarem a aplicabilidade dos conteúdos matemáticos, por isso é importante que o conhecimento do professor não se restrinja apenas ao conteúdo matemático a ser ensinado, mas que contemple o contexto histórico no qual aquele conteúdo foi desenvolvido, que a linguagem alcance o estudante, e sempre que possível é interessante que o professor parta do real, do concreto, das manipulações e associações feitas pelo aluno para a partir daí caminhar no sentido da abstração.

Nesse sentido, mais uma vez, reforçamos a relevância da generalização de padrões para uma melhor compreensão dos conceitos e construções algébricos. Segundo as recomendações dos PCNs "trabalhando com situações-problema, o aluno reconhecerá diferentes funções da álgebra (como modelizar, resolver problemas aritmeticamente insolúveis, demonstrar), representando problemas por meio de equações (identificando parâmetros, variáveis e relações e tomando contato com fórmulas, equações, variáveis e incógnitas) e conhecendo a "sintaxe" (regras para resolução) de uma equação" (Brasil, 1997, p.39).[13]

Alguns professores, ao responderem esse mesmo item, mostraram que a aprendizagem de álgebra, durante o período escolar, aconteceu de forma mecanizada. Um deles afirmou que, enquanto cursava o ensino fundamental e médio, encarava a álgebra como um "processo de repetição". Outro professor usou a expressão "jogo de números, com suas próprias regras" no qual "tudo parecia abstrato" para evidenciar as dificuldades, e ainda destacaram a "rigidez" e o "status de incompreensível" que, de maneira geral, representava a opinião dos estudantes com relação à aprendizagem de álgebra. 
2. Na minha história escolar a álgebra...

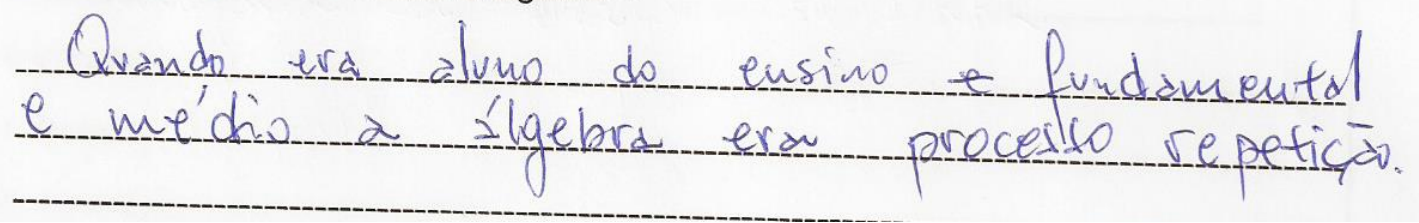

Figura 6.7: Resposta do P3 para o item 2 do questionário.

A afirmação do professor P3 nos levou, mais uma vez, a refletir sobre a forma como a álgebra é ensinada nas escolas, além de evidenciar a impressão que o aluno tem ao lhe dar com os conteúdos e conceitos algébricos. Ribeiro (2015) [55], destaca que a concepção tanto dos professores, quanto dos alunos sobre os conteúdos Equação e Função estão associados às regras e repetições de processos.

Ribeiro (2012) afirma que mesmo após a escolaridade básica dos estudantes, vivenciando conceitos algébricos, os mesmos ainda apontam dificuldades com relação ao significado de equação e função, restringindo tais conceitos a procedimentos e manipulações algébricas e aritméticas.

Mesmo ao final da escolaridade básica, após vivenciarem processos de
aprendizagem de conceitos algébricos fundamentais, como é o caso do
conceito de equação, os alunos (a) não reconhecem as estruturas de
uma equação; (b) não são capazes de apresentar uma caracterização
para o conceito de equação; (c) não significam equação por diferentes
perspectivas, a não ser por seus procedimentos e técnicas de resolução"
e ainda concluiu que é necessário uma "aprendizagem que supere o
mecanicismo e a "falta" de significados para o conceito de equação.
(p.4). [56]

O professor P5 exemplifica um momento das aulas em que o ensino tradicional aparece de forma predominante, apesar do grande esforço por parte dos pesquisadores e educadores, buscando rompimento e modernização, propondo a discussão e construção de novas estratégias para o ensino. 


\section{Na minha história escolar a álgebra....}

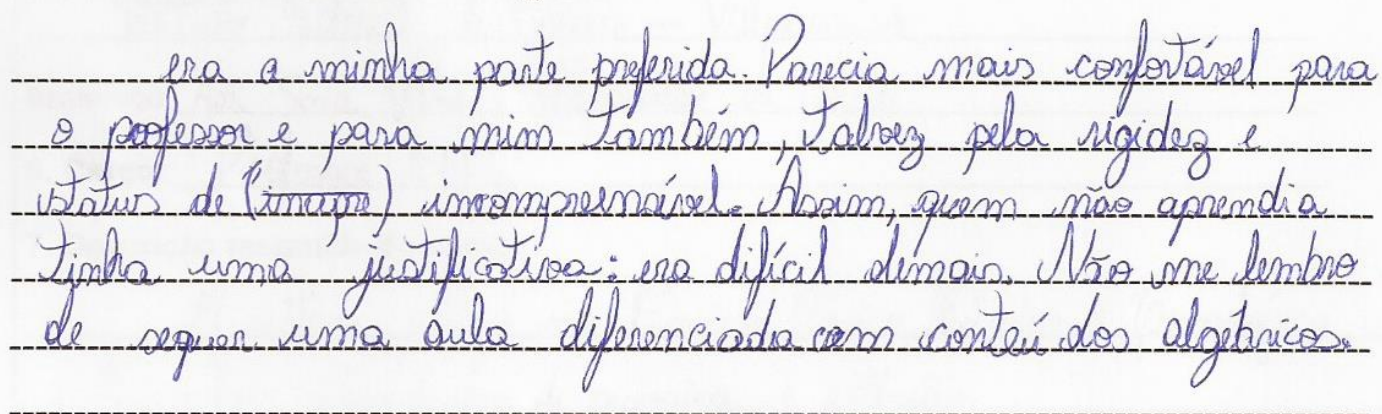

Figura 6.8: Resposta do P5 para o item 2 do questionário

Em suas memórias de aluno, fica claro que não houve momentos em que o professor de álgebra tenha proposto alguma atividade que pudesse facilitar a aprendizagem dos conteúdos, ou mesmo motivar os estudantes para que pudessem formular hipóteses, discutir, construir e significar sua aprendizagem.

A terceira frase, evidenciou que os participantes encaram o ensino de álgebra como um desafio, tendo em vista as dificuldades dos seus alunos e pelo caráter "rígido" próprio dos conteúdos algébricos. As palavras "abstrato" e "difícil" aparecem na maioria das respostas dos professores.

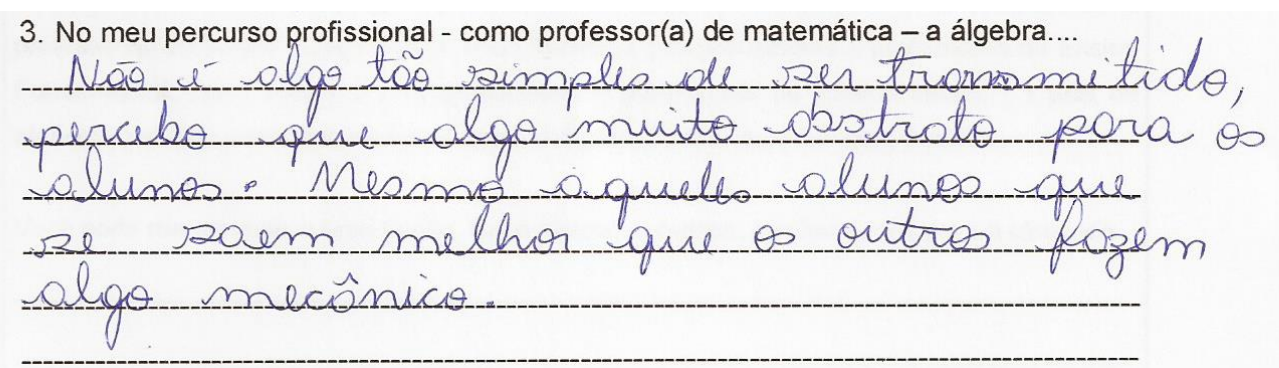

Figura 6.9: Resposta da Pa3 para o item 3 do questionário

A professora Pa3 explica que mesmo os alunos com maior habilidade, ainda utilizam os processos algébricos de forma mecânica, ou seja, distanciados do significado e da apropriação dos conceitos. LIMA(2007), em sua pesquisa sobre equações algébricas no ensino médio, afirma que os métodos de resolução, embora eficazes para determinar a solução de equações, são frágeis porque não permitem que os estudantes conheçam os fundamentos que deram origem as manipulações. 
Esses significados atribuídos aos métodos de resolução usados exercem uma influência ambígua no trabalho com equações. De um lado, o aluno pode ter sucesso com o uso de corporificações procedimentais, pois eles podem obter a resposta correta por meio dessas corporificações. Por outro lado, essas respostas corretas escondem um desconhecimento dos conceitos matemáticos que validam os procedimentos usados, e os alunos não compreendem que eles não são mágicas sem explicação, mas que são técnicas derivadas de princípios algébricos fundamentados por características do mundo formal. O sucesso aparente é frágil e irreal (LIMA, 2007, p.292). 38

Ainda sobre a terceira frase, alguns professores afirmaram gostar do conteúdo e se identificarem, mas relatam que apenas o conhecimento do conteúdo não é suficiente, e que ao ensinar ainda sentem algumas dificuldades na forma de explicar para os estudantes.

3. No meu percurso profissional - como professor(a) de matemática - a álgebra...

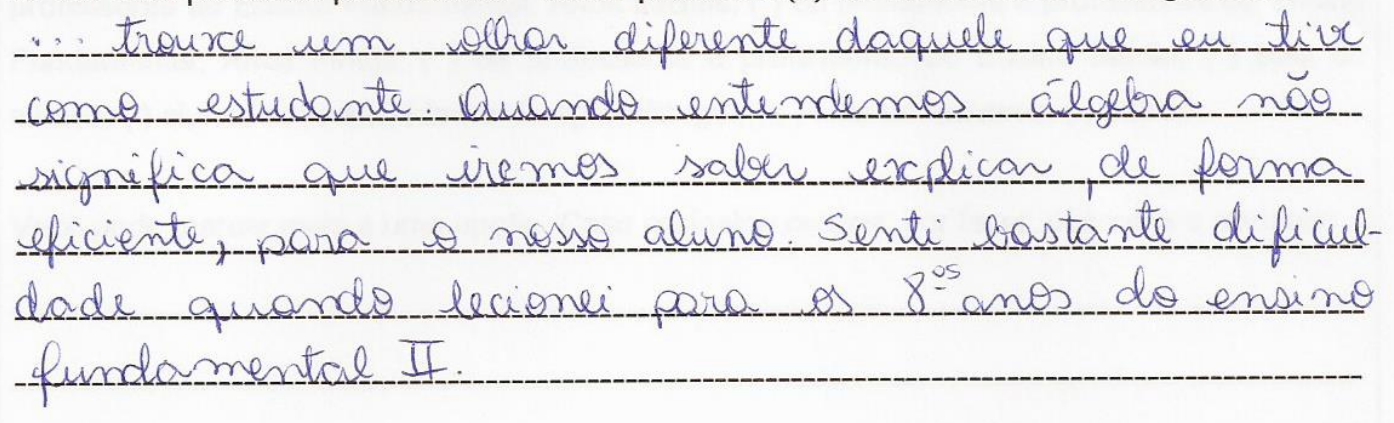

Figura 6.10: Resposta da Pa2 para o item 3 do questionário

Alguns participantes completaram a frase dando ênfase a forma como ensinam os conteúdos algébricos em suas salas de aula. Chamou-nos a atenção, especificamente, a resposta de dois professores, que apresentaram ações e posicionamentos distintos, e que de modo geral, consideramos antagônicos.

3. No meu percurso profissional - como professor(a) de matemática - a álgebra....

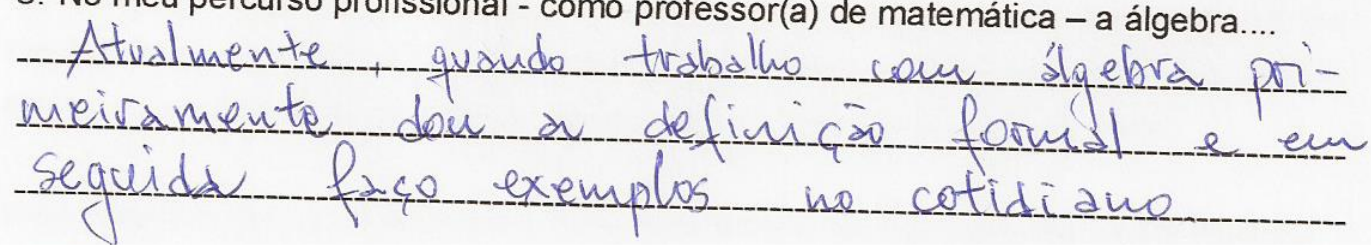

Figura 6.11: Resposta do P3 para o item 3 do questionário

Ao analisarmos a resposta do professor P3, percebemos que acontece uma inversão da proposta recomendada atualmente pelos PCNs, que é partir dos exemplos 
informais, para se chegar as generalizações e posteriormente à formalização de conceitos.

O professor P1, evidencia que distancia-se da forma tradicional como ele aprendeu, na tentativa de promover uma aprendizagem mais significativa para os seus alunos.

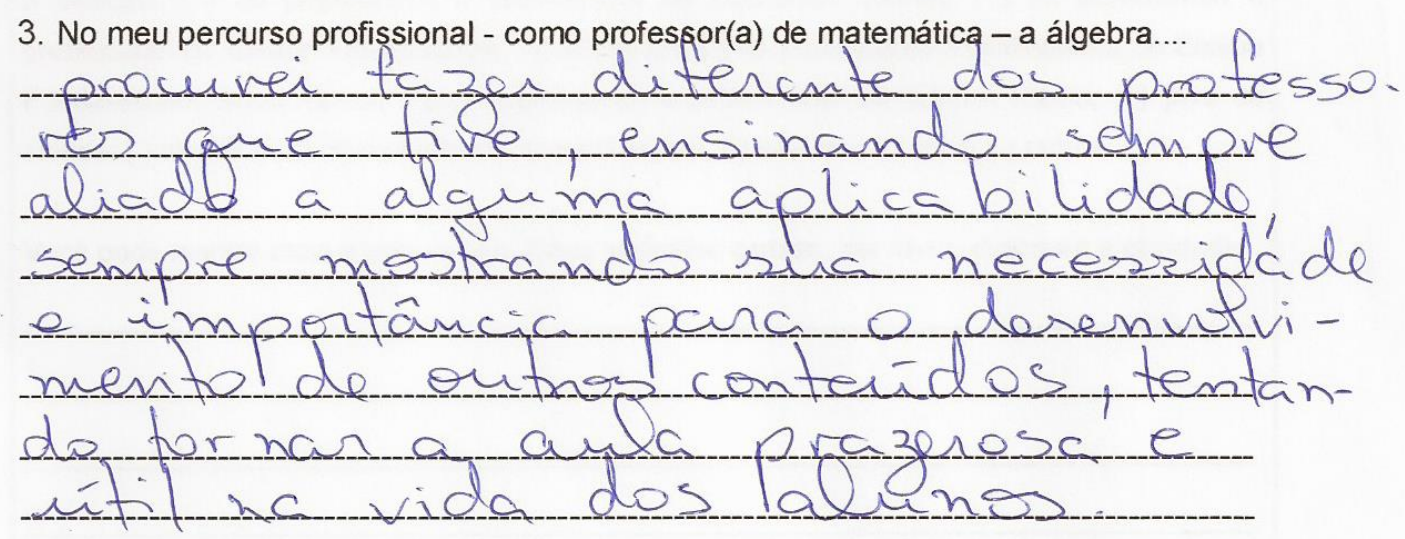

Figura 6.12: Resposta do P1 para o item 3 do questionário

Mais uma vez remetemos a proposta de que o ensino e a aprendizagem dos conteúdos matemáticos aconteçam de forma mais significativa. Segundo D'Ambrosio (2005), o verdadeiro papel da matemática consiste em modelar as situações reais. Logo, a matemática precisa ser utilizada como instrumento, que aplicado a outros contextos, desenvolve-se de forma criativa, facilitando e construindo novos resultados (p.117). Nesse sentido, é importante partirmos dos conhecimentos prévios e das experiências dos estudantes, para dar continuidade ao processo de aprendizagem.

Esse processo de construção e aprendizagem contínuos, D'Ambrosio (2005) classifica como aprendizagem por excelência, caracterizada pela "capacidade de explicar, de apreender e compreender, de enfrentar, criticamente, situações novas", e conclui que "aprender não é o mero domínio de técnicas, habilidades e nem a memorização de algumas explicações e teorias" (p.117).

\subsection{Análise da roda de conversa}

Esse momento da pesquisa, sucedeu a experimentação das atividades de ensino por parte dos professores. Lembramos que na sessão, os participantes vivenciaram cada uma das três atividades de ensino: Boliche Matemático, Trilha das Leis e Batalha Naval, e após esse momento de experimentações, a pesquisadora propôs uma roda de conversa sobre as atividades. Ademais, ressaltamos que, ainda durante o desenvolvimento das mesmas, aconteceram momentos de diálogos e avaliações, que também serão 
considerados para a validação.

Após as primeiras análises dos diálogos, preconizamos duas categorias:

- Categoria 1 - concepção dos professores sobre o ensino e aprendizagem da álgebra e organização do trabalho pedagógico

- Categoria 2 - a validação das atividades de ensino e aprendizagem

Ao analisar as falas dos participantes, observamos que existe uma relação dialógica e de "causa e consequência" entre as categorias propostas. Sabemos que tratando-se de ensino e aprendizagem, os processos não são fechados, pelo contrário, são passíveis de construções, mudanças e desdobramentos. A organização em categorias, no nosso caso, busca uma separação didática, não significando que essa separação exista de forma empírica. Ademais, essas categorias podem se desdobrar em outras variantes.

Durante a análise, por várias vezes, observamos a relação dialógica entre as categorias, e entendemos que a ação emergente em uma delas pode atuar ou implicar em alterações para as demais, inclusive, gerando um processo circular em alguns momentos. A seguir, detalharemos a análise, utilizando as categorias apresentadas, evidenciando as limitações, potencialidades e sugestões imediatas consideradas pelos participantes.

Nesse momento de análise, também faremos inferências relacionadas à bibliografia do trabalho. Além disso, usaremos de forma genuína, de acordo com as transcrições, algumas falas dos participantes dessa pesquisa, visando clarificar as percepções da pesquisadora no contexto. As falas dos participantes serão demarcadas por aspas e escrita em itálico, além da identificação do mesmo, ao final, entre parênteses. 
Categoria 1 - Concepção dos professores sobre o ensino e aprendizagem da álgebra e organização do trabalho pedagógico

\section{Boliche Matemático}

\begin{tabular}{|c|c|c|}
\hline Limitações & Potencialidades & Sugestões imediatas \\
\hline $\begin{array}{l}\text { Organização da sala de } \\
\text { aula, devido à quantidade } \\
\text { de alunos. } \\
\text { "Honestamente eu acho o } \\
\text { boliche meio complicado } \\
\text { para sala de aula...por } \\
\text { causa da movimentação dos } \\
\text { alunos." (Pa1). }\end{array}$ & $\begin{array}{l}\text { Alguns professores conside- } \\
\text { raram que seria possível } \\
\text { e interessante realizar essa } \\
\text { atividade, mesmo dentro do } \\
\text { espaço físico sala de aula. } \\
\text { "Eu acho que vale a pena } \\
\text { você preparar essa aula } \\
\text { mesmo né, dentro da sala } \\
\text { de aula mesmo, afastar to- } \\
\text { das as carteiras e jogar..."' } \\
\text { (P1). }\end{array}$ & $\begin{array}{l}\text { Manter o controle sobre a } \\
\text { turma durante a realização } \\
\text { das atividades. } \\
\text { “...vai funcionar se o pro- } \\
\text { fessor também tiver essa } \\
\text { postura, de saber contro- } \\
\text { lar...” (P5). } \\
\text { Desenvolver o trabalho em } \\
\text { grupos contendo menos es- } \\
\text { tudantes, no contraturno es- } \\
\text { colar. } \\
\text { “...por causa da movi- } \\
\text { mentação dos alunos, eu } \\
\text { faria com grupos... mon- } \\
\text { taria grupos de estudos no } \\
\text { contraturno...”. (Pa1). }\end{array}$ \\
\hline $\begin{array}{l}\text { A mediação de um profes- } \\
\text { sor apenas, não é sufici- } \\
\text { ente para atender toda a de- } \\
\text { manda da turma. } \\
\text { O intervalo entre as joga- } \\
\text { das de cada estudante fica } \\
\text { longo, o que pode provocar } \\
\text { dispersão. } \\
\text { “...as crianças ficam mais } \\
\text { entediadas se tiver que es- } \\
\text { perar cada um jogar uma } \\
\text { vez...” (P4). }\end{array}$ & & $\begin{array}{l}\text { Dividir a turma em grupos e } \\
\text { escolher um estudante como } \\
\text { "juíz" para mediar a ativi- } \\
\text { dade e outro para organizar } \\
\text { os pinos do boliche, anotar } \\
\text { os pontuações. } \\
\text { "O aluno como res- } \\
\text { ponsável..."(P4). } \\
\text { Realizar atividades si- } \\
\text { multâneas. } \\
\text { “...separar a sala em quatro } \\
\text { lugares sei lá, uma coisa as- } \\
\text { sim, e fazer várias coisas si- } \\
\text { multâneas...” (P4). }\end{array}$ \\
\hline
\end{tabular}




\begin{tabular}{|c|c|c|}
\hline $\begin{array}{l}\text { O barulho que poderá inco- } \\
\text { modar os professores e estu- } \\
\text { dantes das outras salas da } \\
\text { escola. } \\
\text { "...se você for pensar, nós } \\
\text { somos todos adultos e fi- } \\
\text { zemos barulho, imagine as } \\
\text { crianças, vão querer come- } \\
\text { morar..." (Pa1). }\end{array}$ & $\begin{array}{l}\text { O aspecto lúdico e envol- } \\
\text { vente da atividade. } \\
\text { “...eu particularmente gosto } \\
\text { do barulho, eu gosto de ba- } \\
\text { rulho até na hora que estou } \\
\text { estudando..." (P5). }\end{array}$ & $\begin{array}{l}\text { Avisar aos demais professo- } \\
\text { res da escola que haverá a } \\
\text { aplicação de uma atividade } \\
\text { que poderá gerar barulho. } \\
\text { "...se vai fazer uma ativi- } \\
\text { dade diferenciada como essa } \\
\text { (pausa), é falar com os ou- } \\
\text { tros professores já antes..." } \\
(\mathrm{P} 4) \text {. }\end{array}$ \\
\hline \multirow[t]{2}{*}{$\begin{array}{l}\text { Ausência de espaços físicos } \\
\text { para realizar a atividade. } \\
\text { Deslocamento dos alunos } \\
\text { para outros espaços da es- } \\
\text { cola, externos à sala de aula. } \\
\text { "...as escolas são tão mal } \\
\text { estruturadas que não tem } \\
\text { um espaço...” (Pa1). } \\
\text { "...tirar da sala de aula, } \\
\text { sabe? A direção nãa vê } \\
\text { com bons olhos, nem coor- } \\
\text { denação...” (Pa1). }\end{array}$} & & $\begin{array}{l}\text { Realizar o trabalho em par- } \\
\text { ceria com outros professo- } \\
\text { res, como por exemplo, os } \\
\text { de educação física, que po- } \\
\text { dem auxiliar quanto à con- } \\
\text { cessão do espaço físico (qua- } \\
\text { dra de esportes), forneci- } \\
\text { mento de bolas e orga- } \\
\text { nização da atividade. } \\
\text { “... mas a gente podia } \\
\text { incluir até o professor de } \\
\text { educação física, com bo- } \\
\text { las, coisas assim, uma gin- } \\
\text { cana...” (P3). }\end{array}$ \\
\hline & $\begin{array}{l}\text { Possibilidade de trabalhar } \\
\text { outros conteúdos além de } \\
\text { expressões algébricas. } \\
\text { "Acho que o trabalho } \\
\text { pode ser usado...como por } \\
\text { exemplo, pensando em } \\
\text { potência...para mostrar o } \\
\text { valor da potência, que é } \\
\text { uma operação que cresce } \\
\text { muito rápido..." (P1). }\end{array}$ & \\
\hline
\end{tabular}




\begin{tabular}{|c|c|c|}
\hline & $\begin{array}{l}\text { Melhora a interação en- } \\
\text { tre os alunos e também } \\
\text { entre o professor e alu- } \\
\text { nos, contribuindo para a } \\
\text { desmistificação do estigma } \\
\text { de inacessibilidade da ma- } \\
\text { temática. } \\
\text { "Nesse tipo de trabalho, é o } \\
\text { trabalho que mais inclui os } \\
\text { alunos, até aquele que nem } \\
\text { fala comigo..."(P1). } \\
\text { "...meninos que não intera- } \\
\text { gem, vão morrer de rir, por- } \\
\text { que um não jogou, ou o ou- } \\
\text { tro...todo mundo vai rir..." } \\
\text { (Pa2). }\end{array}$ & \\
\hline $\begin{array}{l}\text { De maneira geral, os pro- } \\
\text { fessores consideraram como } \\
\text { muito básico a utilização } \\
\text { das rodadas "dobro" e } \\
\text { "quíntuplo". Afirma- } \\
\text { ram ser válidas para um } \\
\text { primeiro momento, de fami- } \\
\text { liarização com a atividade, } \\
\text { e que as manipulações } \\
\text { utilizadas para as próximas } \\
\text { rodadas deveriam ser mais } \\
\text { elaboradas. } \\
\text { "...pra variar, o dobro, o } \\
\text { triplo e o quíntuplo são } \\
\text { tabuadas mais fáceis né... } \\
\text { pode trabalhar com tabuadas } \\
\text { mais difícil..." (Pa1) } \\
\text { "Achei bem legal, só po- } \\
\text { dia dar uma dificultada..." } \\
\text { (Pa3). }\end{array}$ & $\begin{array}{l}\text { Associação das atividades } \\
\text { Boliche Matemático e Trilha } \\
\text { das leis, combinando as suas } \\
\text { regras. Contribuindo para } \\
\text { a aprendizagem do cálculo } \\
\text { de expressões algébricas e } \\
\text { reforçando o estudo das } \\
\text { operações aritméticas. } \\
\text { “...aí combinar aquelas re- } \\
\text { gras que teve na trilha com o } \\
\text { boliche por exemplo...”(P2). }\end{array}$ & $\begin{array}{l}\text { Usar outras manipulações } \\
\text { algébricas, além das já pro- } \\
\text { postas pela pesquisadora. } \\
\text { Uma das sugestões foi mul- } \\
\text { tiplicar as quantidades de } \\
\text { pinos derrubados por outros } \\
\text { valores como o seis, o oito e } \\
\text { o dez. } \\
\text { “... a gente pode usar ou- } \\
\text { tras variações, a gente pode } \\
\text { somar alguma coisa, sei } \\
\text { lá, tipo pegar uma fileira, } \\
\text { multiplica por } 10 \text { números, } \\
\text { e multiplica por outra ter- } \\
\text { ceira...” (P1). }\end{array}$ \\
\hline
\end{tabular}




\begin{tabular}{|c|c|c|}
\hline $\begin{array}{l}\text { Os professores apontaram } \\
\text { que os estudantes têm di- } \\
\text { ficuldades com as repre- } \\
\text { sentações e o simbolismo } \\
\text { algébrico. } \\
\text { “...transcrever isso eles tem } \\
\text { uma dificuldade, por exem- } \\
\text { plo, } 6^{o} \text { ano, eles escreverem } \\
\text { as ideias que eles têm, as } \\
\text { ideias matemáticas que eles } \\
\text { têm, é muito difícil... (P5). }\end{array}$ & $\begin{array}{l}\text { A partir da atividade os } \\
\text { professores podem orien- } \\
\text { tar para que os estudantes } \\
\text { criem funções. } \\
\text { Consideram que a ativi- } \\
\text { dade contribui para desper- } \\
\text { tar, de forma intuitiva, o } \\
\text { uso da simbologia para as } \\
\text { representações, facilitando a } \\
\text { compreensão da passagem } \\
\text { da língua natural para a lin- } \\
\text { guagem algébrica. } \\
\text { “...ou criar uma função...” } \\
\text { (P3). }\end{array}$ & $\begin{array}{l}\text { Fazer o registro da atividade } \\
\text { de forma oral, auxiliando os } \\
\text { alunos para que consigam } \\
\text { construir e apropriar-se da } \\
\text { simbologia algébrica. } \\
\text { “...pode ser baseado na vali- } \\
\text { dade mesmo, o aluno expli- } \\
\text { car isso falando...” (P5). }\end{array}$ \\
\hline
\end{tabular}

\section{Trilha das leis}

\begin{tabular}{|c|c|c|}
\hline & otencialidades & Sugestões imediatas \\
\hline $\begin{array}{l}\text { Alguns professores, consi- } \\
\text { deraram os cálculos fáceis, } \\
\text { especialmente as "leis" es- } \\
\text { critas nas cartas, pontu- } \\
\text { ando que as manipulações } \\
\text { algébricas enunciadas são } \\
\text { elementares, havendo uma } \\
\text { necessidade de reformulação } \\
\text { a partir do ano em que a ati- } \\
\text { vidade será aplicada. } \\
\text { "...o professor vai de- } \\
\text { cidir essas questões, se } \\
\text { eu quero no início do } 6^{\circ} \\
\text { ano por exemplo, que tão } \\
\text { lá nas operações, então, } \\
\text { então... são essas operações } \\
\text { básicas...". (P5). }\end{array}$ & $\begin{array}{l}\text { Incluir cartas contendo } \\
\text { operações com números } \\
\text { inteiros. } \\
\text { "Agora se de repente, } \\
\text { joga com o sétimo ano, } \\
\text { de alguma forma, algo } \\
\text { com números negativos, } \\
\text { ai vai...aproveitar essa } \\
\text { flexibilidade." (P5). } \\
\text { "Vai cobrar justamente no } \\
\text { sétimo ano os componen- } \\
\text { tes dos números inteiros né, } \\
\text { aí então, se eles acertam } \\
\text { os pontos positivos eles vão } \\
\text { para frente, se for números } \\
\text { negativos, vai para trás..." } \\
\text { (P1). }\end{array}$ & $\begin{array}{l}\text { Colocar outras mani- } \\
\text { pulações algébricas um } \\
\text { pouco mais elaboradas e } \\
\text { não tão diretas como as } \\
\text { utilizadas nas cartas dessa } \\
\text { atividade. } \\
\text { “...e as fichinhas tem que } \\
\text { ser mais dificultadas..." } \\
\text { (Pa3). } \\
\text { "Já poderia colocar assim, } \\
\text { aí ia ser legal nem sempre } \\
\text { tirar número muito grande } \\
\text { ou muito pequeno, é, se- } \\
\text { ria.... (Pa2 sobre a in- } \\
\text { clusão de números negativos } \\
\text { na atividade). }\end{array}$ \\
\hline
\end{tabular}




\begin{tabular}{|c|c|c|}
\hline & $\begin{array}{l}\text { No início os professores } \\
\text { acharam que a atividade } \\
\text { terminaria rápido, no en- } \\
\text { tanto, apontaram que os co- } \\
\text { mandos "volte ao início" e } \\
\text { "volte "x' casas" prolonga- } \\
\text { ram a atividade, e que hipo- } \\
\text { teticamente forçaria os estu- } \\
\text { dantes a executarem vários } \\
\text { cálculos. } \\
\text { "Mas é a intenção, porque } \\
\text { você pensa, se o jogo ter- } \\
\text { minar rápido o aluno quase } \\
\text { não faz ponto..." (P5). }\end{array}$ & \\
\hline $\begin{array}{l}\text { Um professor questionou so- } \\
\text { bre as possíveis dificulda- } \\
\text { des dos estudantes ao rea- } \\
\text { lizarem os cálculos mental- } \\
\text { mente. No entanto, a maior } \\
\text { parte dos professores consi- } \\
\text { derou que seria mais inte- } \\
\text { ressante incentivar os estu- } \\
\text { dantes a fazerem os cálculos } \\
\text { mentalmente. }\end{array}$ & & $\begin{array}{l}\text { Realização de duas etapas } \\
\text { da atividade, uma primeira } \\
\text { fornecendo rascunho para } \\
\text { que os alunos executem os } \\
\text { cálculos, que inclusive po- } \\
\text { dem servir como registro } \\
\text { a ser analisado posterior- } \\
\text { mente, pelo professor, e } \\
\text { uma segunda etapa na qual } \\
\text { os cálculos serão executados } \\
\text { apenas mentalmente. } \\
\text { "Numa segunda etapa, } \\
\text { de repente pode trabalhar } \\
\text { cálculo mental mesmo..." } \\
\text { (P5). } \\
\text { "Ele tem que fazer de cabeça } \\
\text { mesmo..." (Pa3). } \\
\text { "Eu acho que esse tipo de } \\
\text { coisa era pra ser de cabeça" } \\
\text { (Pa1). }\end{array}$ \\
\hline
\end{tabular}




\begin{tabular}{|c|c|c|}
\hline $\begin{array}{l}\text { Como fazer a avaliação } \\
\text { dos registros dos estudan- } \\
\text { tes, uma vez que os mesmos } \\
\text { tem liberdade para registrar } \\
\text { a "lei impressa nas cartas" } \\
\text { da forma como lhes convém. } \\
\text { "...ele pode escrever da } \\
\text { forma que ele quiser, por } \\
\text { exemplo aqui na lei." (Pa2) }\end{array}$ & $\begin{array}{l}\text { Consideram que a atividade } \\
\text { contribui para que os es- } \\
\text { tudantes pratiquem cálculos } \\
\text { mentalmente. } \\
\text { "a gente pode trabalhar o } \\
\text { cálculo mental." }\end{array}$ & 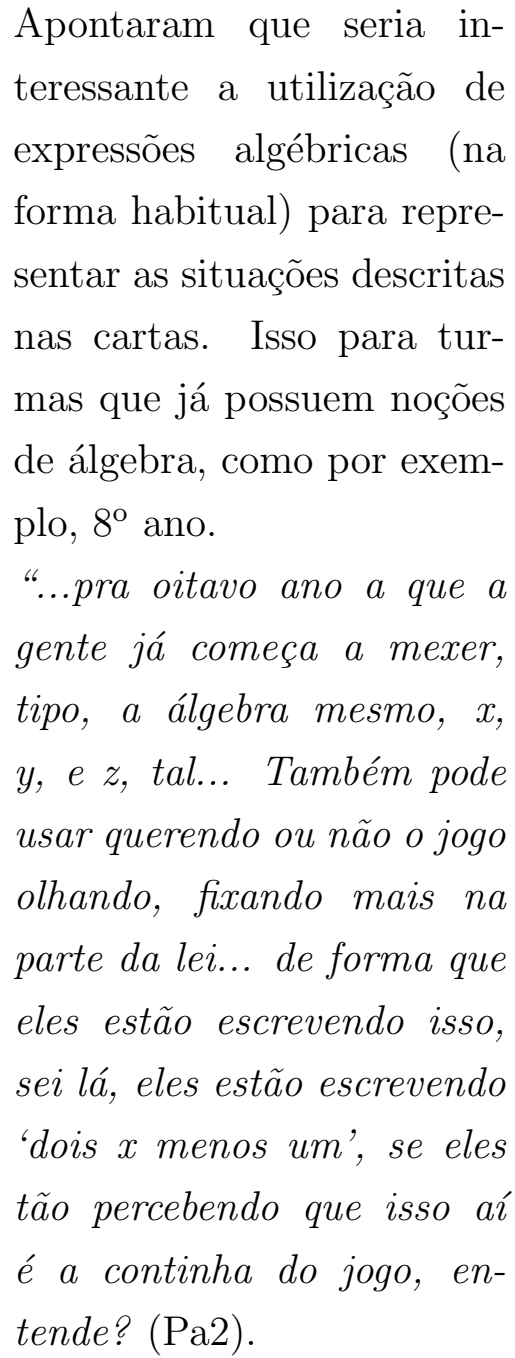 \\
\hline & $\begin{array}{l}\text { Os professores apontaram } \\
\text { que a atividade pode ser } \\
\text { adaptada a vários outros } \\
\text { níveis, dependendo do } \\
\text { conteúdo e da intencionali- } \\
\text { dade do professor. } \\
\text { "Mas dá pra usar inclu- } \\
\text { sive no } 8^{\circ} \text { ano, seria muito } \\
\text { bom." (Pa2). }\end{array}$ & \\
\hline
\end{tabular}




\begin{tabular}{|c|c|c|}
\hline & $\begin{array}{l}\text { Acreditam que essa ativi- } \\
\text { dade pode auxiliar no pro- } \\
\text { cesso de aprendizagem e } \\
\text { apropriação da linguagem } \\
\text { formal própria da álgebra. } \\
\text { “...olha, o } 8^{o} \text { ano começa } \\
\text { a encarar o x como um } \\
\text { número que ele não sabe } \\
\text { que é uma variável, é muito } \\
\text { chato e talvez com o jogo } \\
\text { isso fica muito mais fácil...” } \\
\text { (Pa2). }\end{array}$ & $\begin{array}{l}\text { Escrever as expressões } \\
\text { algébricas nas "cartas" } \\
\text { da atividade, usando a } \\
\text { linguagem matemática } \\
\text { algébrica. } \\
\text { "as cartinhas.. também } \\
\text { com leis, assim, com leis } \\
\text { algébricas, por exemplo, } \\
\text { cartinhas valendo } 2 x+5 \\
\text { (Pa1). } \\
\text { Sugerir aos estudantes que } \\
\text { a escrevam a lei contida na } \\
\text { carta, na forma algébrica. } \\
\text { "Ele pode, ele escrever a ex- } \\
\text { pressão a partir da carti- } \\
\text { nha..." (P5). }\end{array}$ \\
\hline \multicolumn{3}{|c|}{ Batalha Naval } \\
\hline & $\begin{array}{l}\text { Consideram que essa ati- } \\
\text { vidade pode ser utilizada } \\
\text { para trabalhar os conteúdos } \\
\text { relacionados à simetria e } \\
\text { translação. } \\
\text { "Agora se você quer tra- } \\
\text { balhar com simetria, exce- } \\
\text { lente isso que ela fez, tá en- } \\
\text { tendendo? Que aí ele vai } \\
\text { ter que perceber, e, "Nossa, } \\
\text { percebi. É simetria! Aí be- } \\
\text { leza, então agora vai." De- } \\
\text { pende do foco né?" (P1). } \\
\text { "Até translação também dá } \\
\text { pra trabalhar" (P3). }\end{array}$ & $\begin{array}{l}\text { Construir os eixos, usando } \\
\text { números positivos e negati- } \\
\text { vos, como por exemplo, do } \\
\text { número }-4 \text { ao }+4 \text {. } \\
\text { "...mas aí eu vou fazer os } \\
\text { eixos, vou fazer o eixo x to- } \\
\text { dinho do jeito que eu falei, } \\
\text { com os negativos né, porque } \\
\text { eu vou trabalhar também os } \\
\text { negativos, e aí, eu vou pin- } \\
\text { tar..." (P1). } \\
\text { "É. Você até mostra né, } \\
\text { quem é o oposto de tal, tal" } \\
\text { (Pa2). }\end{array}$ \\
\hline
\end{tabular}


Consideram que os submarinos, não atendem o objetivo da atividade, uma vez que naufragam com apenas uma coordenada (tiro). Logo, a escolha dos estudantes é aleatória, sem considerar a vizinhança do submarino no campo de batalha. Já as outras embarcações, por ocuparem mais de uma coordenada no campo de batalha, levam os estudantes a usarem a função, afim de descobrirem qual coordenada associaria aquele exato ponto no plano.
Retirar os submarinos e usar apenas as embarcações maiores, que ocupem pelo menos duas coordenadas do campo de batalha.

"Diminui os submarinos né" (P1).

"É. Até porque aí ele vai pro foco mesmo, não de ficar falando aleatório. Ele acerta um e aí ele sabe aonde é que ele tem que falar agora" (P1).

"Não, eu acho assim, tem que retirar o submarino, porque o submarino, o foco é a sorte, mas se você colocar os compridinhos, você consegue, o aluno começa a definir os pontos" (P3). 


\begin{tabular}{l|l}
\hline $\begin{array}{l}\text { A função de associação das } \\
\text { linhas e colunas é um pouco } \\
\text { complicada. }\end{array}$ & $\begin{array}{l}\text { Criar uma função (lei) única } \\
\text { para associação de linhas }\end{array}$ \\
e colunas, como por exem- \\
plo, deslocar duas unidades \\
a partir de cada coordenada \\
enunciada pelo estudante. \\
“...Todo par que ele falar, \\
você vai tirar duas unida- \\
des, e se acabar pra cá, des- \\
loca e volta pra cá. Né? \\
Acho que dá...dá. Acho \\
que pra essa ideia de... de \\
função, acho que dá pra en- \\
tender né, a relação bem \\
com os alunos, pra iniciar a \\
ideia de função?" (P5). \\
"É porque seria, se você fala \\
o (2,2) é o (4,4)" (Pa2).
\end{tabular}

Tabela 6.1: Roda de conversa - Categoria 1 
Categoria 2 - A validação das atividades de ensino e aprendizagem

\begin{tabular}{|c|c|c|}
\hline \multicolumn{3}{|c|}{ Boliche Matemático } \\
\hline Limitações & Potencialidades & Sugestões imediatas \\
\hline $\begin{array}{l}\text { Os pinos e a bola fo- } \\
\text { ram construídos com ma- } \\
\text { terial plástico leve, o que } \\
\text { fez com que a mesma per- } \\
\text { desse força durante o per- } \\
\text { curso, diminuindo a quanti- } \\
\text { dade de acertos e pinos der- } \\
\text { rubados. Logo, os profes- } \\
\text { sores consideraram que os } \\
\text { estudantes, ao jogar, pode- } \\
\text { riam ficar com a pontuação } \\
\text { pequena ou igual a zero. } \\
\text { "A maioria fica zero, que- } \\
\text { rendo ou não, zera... o pe- } \\
\text { sado provavelmente os me- } \\
\text { ninos derrubariam muito, } \\
\text { muito mais que a gente tal- } \\
\text { vez..." (Pa2). }\end{array}$ & $\begin{array}{l}\text { Consideraram o material in- } \\
\text { teressante e a atividade di- } \\
\text { vertida. } \\
\text { "É um material bem inte- } \\
\text { ressante..." (P4). } \\
\text { "...É divertido..." (Pa3) } \\
\text { "Achei bem legal..." (Pa3). }\end{array}$ & $\begin{array}{l}\text { Construir pinos de boliche } \\
\text { com material mais pesado, } \\
\text { de forma que pudesse utili- } \\
\text { zar as bolas esportivas, con- } \\
\text { tidas na escola, para rea- } \\
\text { lização da atividade. } \\
\text { Utilizar garrafas pet e areia } \\
\text { para produção de pinos } \\
\text { mais pesados. } \\
\text { “...eles mesmo pegarem as } \\
\text { garrafas e de repente até } \\
\text { enfeitarem as garrafas..." } \\
\text { (P5). }\end{array}$ \\
\hline $\begin{array}{l}\text { Ainda sobre o registro, os } \\
\text { professores afirmaram que } \\
\text { questionar o estudante so- } \\
\text { bre qual rodada seria a mais } \\
\text { importante, poderia gerar } \\
\text { ambiguidade, uma vez que } \\
\text { a quantidade de pinos der- } \\
\text { rubados influencia na pon- } \\
\text { tuação. Por exemplo, der- } \\
\text { rubar } 9 \text { pinos na rodada } \\
\text { do dobro acaba deixando-a } \\
\text { mais significativa que derru- } \\
\text { bar } 2 \text { pinos na rodado do tri- } \\
\text { plo. }\end{array}$ & & $\begin{array}{l}\text { Mais uma vez mencionaram } \\
\text { a importância da mediação } \\
\text { do professor e também dos } \\
\text { questionamentos para a } \\
\text { conclusão da atividade. } \\
\text { Consideram que no } 2^{\circ} \\
\text { momento do boliche é } \\
\text { importante estimar uma } \\
\text { pontuação a ser atingida, de } \\
\text { forma que os grupos tentem } \\
\text { organizar os pontos para se } \\
\text { aproximar ao máximo dessa } \\
\text { pontuação. }\end{array}$ \\
\hline
\end{tabular}




\begin{tabular}{|c|c|c|}
\hline & $\begin{array}{l}\text { Os professores foram } \\
\text { unânimes ao concordar que } \\
\text { por meio dessa atividade é } \\
\text { possível que os estudantes } \\
\text { percebam a relação de de- } \\
\text { pendência entre a expressão } \\
\text { e variável. } \\
\text { “...na verdade eu acho que } \\
\text { atinge bem a atividade...” } \\
\text { (Pa2 sobre o objetivo de sig- } \\
\text { nificar a atividade). } \\
\text { “...vão entender essa de- } \\
\text { pendência dos números } \\
\text { maior ou menor...” (P4 } \\
\text { sobre uma maior ou me- } \\
\text { nor quantidade de pinos } \\
\text { derrubados durante os } \\
\text { lançamentos do boliche). }\end{array}$ & \\
\hline $\begin{array}{l}\text { A quantidade de material } \\
\text { não é suficiente para aten- } \\
\text { der toda a demanda da } \\
\text { turma. }\end{array}$ & & $\begin{array}{l}\text { Produzir coletivamente } \\
\text { o material junto com a } \\
\text { própria turma, e usar } \\
\text { objetos recicláveis para } \\
\text { construção desse material, } \\
\text { barateando os custos da } \\
\text { produção para uma grande } \\
\text { quantidade de alunos. } \\
\text { “...E! Então, envolvem eles } \\
\text { na produção do jogo, acho } \\
\text { que esse é o barato, muito } \\
\text { bacana...” (P1). }\end{array}$ \\
\hline
\end{tabular}




\begin{tabular}{|c|c|}
\hline & $\begin{array}{l}\text { Alguns professores suge- } \\
\text { riram trocar o material } \\
\text { utilizado para essa ativi- } \\
\text { dade, substituindo os pinos } \\
\text { de boliche por latas de } \\
\text { alumínio empilhadas que } \\
\text { seriam então derrubadas } \\
\text { por uma bola menor, como } \\
\text { de tênis, por exemplo. } \\
\text { “...ao invés de fazer o bo- } \\
\text { liche, a gente pode fazer } \\
\text { aquelas brincadeiras, que } \\
\text { incentiva o aluno, as lati- } \\
\text { nhas empilhadas e derrubar } \\
\text { com uma bolinha. E tem a } \\
\text { mesma vantagem, vai der- } \\
\text { rubar a quantidade e tal, e } \\
\text { a gente consegue fazer tal- } \\
\text { vez mais atividades na sala } \\
\text { separados,... fazer coisas si- } \\
\text { multâneas." (P4). }\end{array}$ \\
\hline \multicolumn{2}{|c|}{ Trilha das Leis } \\
\hline $\begin{array}{l}\text { A utilização do registro es- } \\
\text { crito pode representar uma } \\
\text { dificuldade para os estudan- } \\
\text { tes, dependendo do nível em } \\
\text { que for aplicada. "As ve- } \\
\text { zes escrever é uma dificul- } \\
\text { dade grande. Até mesmo, } \\
\text { eles falando, a discussão so- } \\
\text { bre isso, o professor pergun- } \\
\text { tando já é difícil." (P5). }\end{array}$ & $\begin{array}{l}\text { Uso da oralidade, questio- } \\
\text { nando os estudantes a res- } \\
\text { peito da atividade desenvol- } \\
\text { vida. } \\
\text { “... "pega a pontuação de } \\
\text { dois, três, x, coloca no qua- } \\
\text { dro, discute primeiro um, } \\
\text { forma uma conclusão... de- } \\
\text { pois eles fazem cada um de- } \\
\text { les... como que uma ori- } \\
\text { entação." (P4). }\end{array}$ \\
\hline
\end{tabular}




\begin{tabular}{|c|c|c|}
\hline $\begin{array}{l}\text { Mais uma vez consideraram } \\
\text { que, um professor apenas } \\
\text { não é suficiente para mediar } \\
\text { a atividade, pois seria ne- } \\
\text { cessário o acompanhamento } \\
\text { de cada grupo de estudantes } \\
\text { individualmente, uma vez } \\
\text { que o registro não é sufici- } \\
\text { ente para garantir que os es- } \\
\text { tudantes marquem os pon- } \\
\text { tos e movimentem-se corre- } \\
\text { tamente. } \\
\text { "Uma coisa que eu fico } \\
\text { preocupado assim com es- } \\
\text { sas atividades é a gente } \\
\text { não conseguir acompanhar a } \\
\text { turma no que fazer, não tem } \\
\text { uma resposta certa, pra dar, } \\
\text { posso dizer que deu cinco, aí } \\
\text { todo mundo confere se deu } \\
\text { cinco, então se ele errar a } \\
\text { conta..." (P4). }\end{array}$ & $\begin{array}{l}\text { O desenvolvimento da au- } \\
\text { tonomia dos estudantes du- } \\
\text { rante a promoção da ativi- } \\
\text { dade. } \\
\text { "...mas isso aí até acho } \\
\text { interessante, que aí os } \\
\text { próprios alunos cuidam } \\
\text { da avaliação da própria } \\
\text { atividade o tempo todo..." } \\
\text { (P5). }\end{array}$ & $\begin{array}{l}\text { Orientar para que todos os } \\
\text { estudantes falem em voz } \\
\text { alta e confiram não só } \\
\text { a própria pontuação, mas } \\
\text { também todas as jogadas de } \\
\text { cada colega. } \\
\text { “...Vai conferir se todos os } \\
\text { colegas tá certo...” (P4). } \\
\text { “...Mas tipo assim, passar } \\
\text { essa orientação." (P2). } \\
\text { "Explicar também assim, se } \\
\text { eles não conferir os dos } \\
\text { outros, os outros podem } \\
\text { dar uns de espertinhos...”. } \\
\text { (Pa1). }\end{array}$ \\
\hline $\begin{array}{l}\text { Embora tenham gostado } \\
\text { das cores e da ilustração, } \\
\text { foram unânimes ao afirmar } \\
\text { que o tabuleiro tem poucas } \\
\text { "casas". } \\
\text { "Porque pelas cartas que eu } \\
\text { vi ali, sei lá, a gente poderia } \\
\text { tirar vinte, entendeu? Pô, } \\
\text { vinte eu acho que deve ser } \\
\text { mais ou menos a metade do } \\
\text { tabuleiro já." (P4). }\end{array}$ & & $\begin{array}{l}\text { Construir um tabuleiro com } \\
\text { maior quantidade de "ca- } \\
\text { sas". } \\
\text { "Eu acho que tem que ser } \\
\text { um pouco maior... mais ca- } \\
\text { sas." (Pa1). } \\
\text { "Mais casas e não maior..." } \\
(\mathrm{P} 2) \text {. }\end{array}$ \\
\hline
\end{tabular}




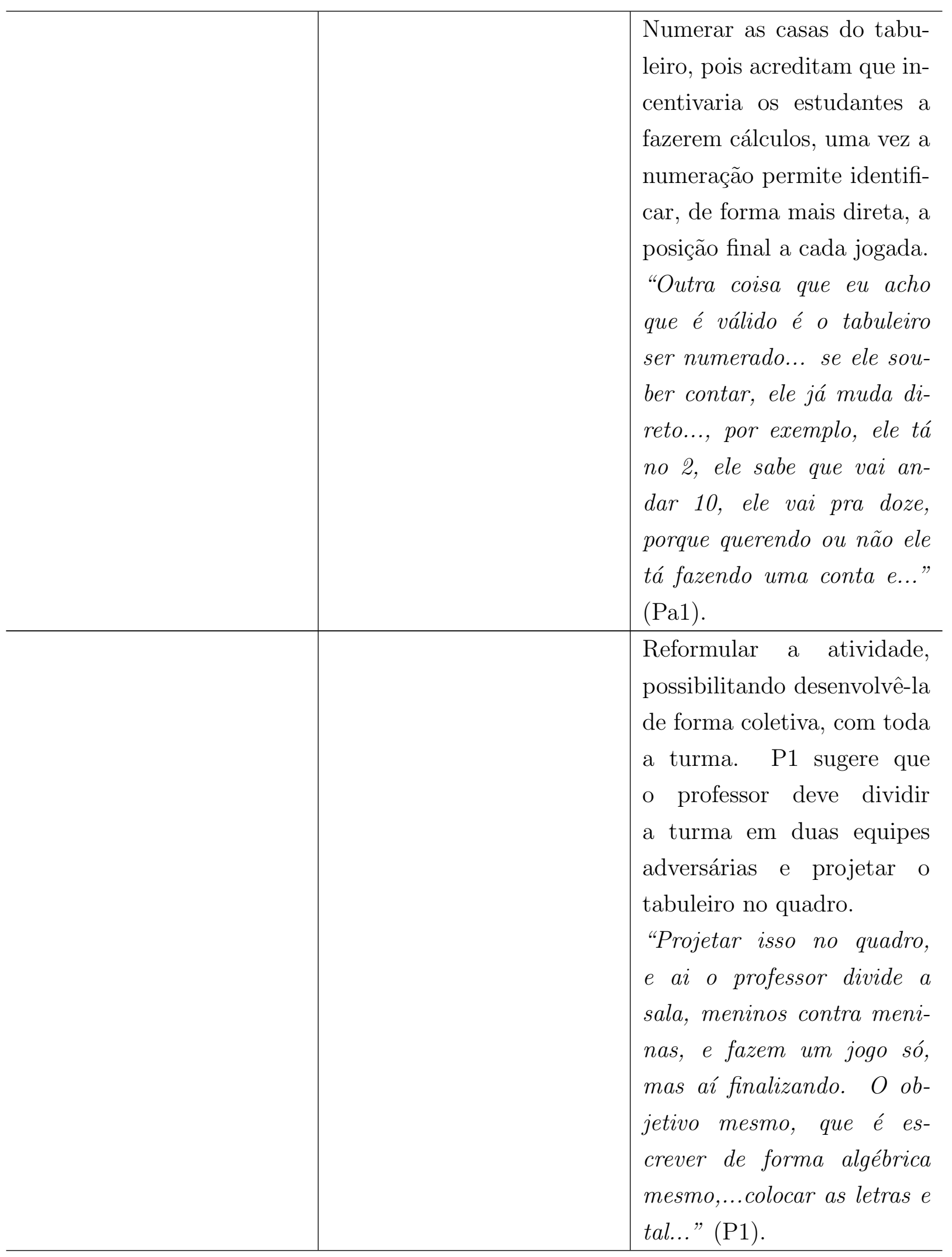




\begin{tabular}{|c|c|}
\hline & $\begin{array}{l}\text { Não utilizar cartas para essa } \\
\text { atividade, propondo apenas } \\
\text { a combinação entre dados } \\
\text { de cores distintas e mo- } \\
\text { vimentação no tabuleiro a } \\
\text { partir dos números sortea- } \\
\text { dos nos três dados. Cada } \\
\text { dado, estaria associado a } \\
\text { um lei, criando assim uma } \\
\text { expressão maior contendo } \\
\text { três termos algébricos. } \\
\text { “...por exemplo, você pega } \\
\text { uma cor, é...seria a letra A, } \\
\text { outra cor X, mais ou me- } \\
\text { nos B, aí seriam três da- } \\
\text { dos, aí você poderia mani- } \\
\text { pular as contas a partir dos } \\
\text { três dados." (P3). } \\
\text { "Exato, ia ser interessante } \\
\text { mesmo..." (Pa2). } \\
\text { "E você pode atribuir pesos } \\
\text { nos dados, o dado de cor } \\
\text { azul ele tem peso dois, já } \\
\text { fica 2y, de repente pode fa- } \\
\text { zer essas manipulações aí." } \\
\text { (P5). }\end{array}$ \\
\hline \multicolumn{2}{|c|}{ Batalha Naval } \\
\hline $\begin{array}{l}\text { O tempo gasto para o de- } \\
\text { senvolvimento da atividade } \\
\text { é longo. }\end{array}$ & $\begin{array}{l}\text { Para otimizar o tempo, um } \\
\text { dos professores sugeriu levar } \\
\text { as embarcações já posicio- } \\
\text { nadas no campo de batalha. }\end{array}$ \\
\hline
\end{tabular}




\begin{tabular}{|c|c|c|}
\hline & $\begin{array}{l}\text { Contribuições para o ensino } \\
\text { de coordenadas no plano } \\
\text { cartesiano. } \\
\text { "É porque eles estão apren- } \\
\text { dendo as coordenadas, que- } \\
\text { rendo ou não a gente re- } \\
\text { laciona, por exemplo, com } \\
\text { o plano cartesiano, então é } \\
\text { interessante realmente nãa } \\
\text { mudar, deixar que aí eles } \\
\text { vão realmente olhar aquele } \\
\text { ponto, ..." (Pa2). }\end{array}$ & $\begin{array}{l}\text { Propor para um segundo } \\
\text { momento, a substituição } \\
\text { da combinação de letras e } \\
\text { números no campo de ba- } \\
\text { talha, para pares ordenados } \\
\text { contendo apenas números. } \\
\text { “... primeiro momento } \\
\text { você poderia trabalhar coma } \\
\text { a letra e o número, depois a } \\
\text { parte de baixo você colocaria } \\
\text { número e número, aí você } \\
\text { fala, falaria que aqui seria } \\
\text { o eixo x, aqui seria o eixo y, } \\
\text { ai ele já tem que trabalhar } \\
\text { na forma certa, do plano } \\
\text { cartesiano..." (P3). } \\
\text { “...mesmo antes de estu- } \\
\text { dar o plano cartesiano, vocêe } \\
\text { pode fazer esse jogo e definir } \\
\text { "Olha, a ordem é essa”, de- } \\
\text { pois você expande pro plano } \\
\text { cartesiano e explica o par } \\
\text { ordenado, que é naquela or- } \\
\text { dem” (P5). }\end{array}$ \\
\hline
\end{tabular}




\begin{tabular}{|c|c|}
\hline $\begin{array}{l}\text { Consideraram que em um } \\
\text { primeiro momento, a asso- } \\
\text { ciação entre as linhas, por } \\
\text { meio das funções pode con- } \\
\text { fundir os estudantes. } \\
\text { "Pois é, eu ia falar, pode pa- } \\
\text { recer bobagem, mas eu colo- } \\
\text { caria as letras embaixo, só } \\
\text { pra ter mais associação com } \\
\text { o plano cartesiano" (P4). }\end{array}$ & $\begin{array}{l}\text { Dividir em dois momentos: } \\
\text { um primeiro no qual os es- } \\
\text { tudantes dão as coordena- } \\
\text { das e elas são marcadas exa- } \\
\text { tamente igual no campo de } \\
\text { batalha, e um segundo mo- } \\
\text { mento, no qual haverá a mu- } \\
\text { dança de coordenadas a par- } \\
\text { tir da "função". } \\
\text { "Eu acho que no primeiro } \\
\text { momento, o primeiro con- } \\
\text { tato com esse jogo, eles tem } \\
\text { que, tem que ser na mesma } \\
\text { posição." (Pa1). } \\
\text { “... sem regra de mudança. } \\
\text { A1 é A1, B2 é B2, do jeito } \\
\text { que for." (Pa1). } \\
\text { Mudar as letras da parte su- } \\
\text { perior para a inferior refe- } \\
\text { renciando ao plano cartesi- } \\
\text { ano, visando facilitar a vi- } \\
\text { sualização e associação por } \\
\text { parte dos estudantes. }\end{array}$ \\
\hline
\end{tabular}

Tabela 6.2: Roda de conversa - Categoria 2

A reformulação da atividade Batalha Naval por P1, devido à estética não constará na tabela e será apresentada a seguir.

O participante P1 propôs uma reformulação da atividade, de forma que ela pudesse ser aplicada para uma maior quantidade de alunos. O professor levaria o campo de batalha com as embarcações já posicionadas, e a partir daí os estudantes tentariam descobrir as posições das mesmas. O professor sorteia o estudante e o mesmo tem que direito a uma coordenada, ou um "tiro".

“E eu assim, para otimizar o tempo, eu vou fazer assim... vi a ideia, gostei, mas vou fazer umas adaptações para otimizar o tempo, a primeira é eu já vou trazer isso, não vou deixar eles preencher não. Eles vão ter que descobrir o que eu preenchi, tá entendendo? Vai ser menino contra menina, mas vai ser aleatório na chamada,... 
eu vou botar os números deles num saquinho e vou pegar. Fulano, número dezessete, e ele tem que falar rápido, vou dar tempo, porque senão eles não concentram, começam a ficar dispersos e aí na hora que eu chamar, eu vou falar, e eles têm, quando eu falar o número você tem 5 segundos pra falar. Porque se ele não tiver ligado, ele vai dar o tiro perdido, e vai haver o tiro perdido... porque ele não estava prestando atenção" (P1).

\subsection{Conclusões}

A partir das ponderações feitas pelos professores, por meio dos questionários e das filmagens, e considerando a bibliografia utilizada para a pesquisa, propomos a apresentação de algumas conclusões que visam a validação das atividades de ensino à luz do processo de ensino e aprendizagem de expressões algébricas.

A primeira categoria concepção dos professores sobre o ensino e aprendizagem de álgebra e organização do trabalho pedagógico discute os aspectos pedagógicos que envolvem as atividades. Nesse sentindo, observamos que alguns apontamentos foram problemáticos. Os principais exemplos dizem respeito à ausência de espaços físicos nas escolas, onde possam ser realizadas atividades de ensino que envolvem jogos pedagógicos, bem como a dificuldade das instituições de ensino em fornecer ao professor material para a construção das atividades e formação de uma equipe capaz de desenvolver o trabalho e mediação nos momentos de efetiva realização das atividades.

Diante dessas limitações, os professores sugeriram ações alternativas que possibilitam a realização das atividades dentro do contexto escolar. Nesse sentido, observamos timidez com relação ao rompimento com a forma de ensino tradicional, uma vez que os professores apresentaram sugestões para adaptar as atividades e não o ambiente escolar. Apenas um dos professores insistiu na realização da atividade da forma original, adaptando sua sala de aula, para que a mesma fosse realizada.

Logo, entendemos que mesmo compreendendo a necessidade de mudanças no processo de ensino e aprendizagem, entre outras mudanças das quais emergem as escolas atuais, os professores, de certo modo, mostram-se resistentes quanto à mudança na forma de organização dos estudantes dentro da sala e utilização de espaços físicos externos à sala de aula e extra escolares.

No entanto, esse processo de busca por novos caminhos e adaptações tornando possível a aplicação das atividades, foi influenciado principalmente por dois motivos: a percepção do grupo com relação à utilização, em salas de aula, de "atividades diferenciadas das tradicionais" e o perfil dos professores participantes da pesquisa.

No tocante à essas atividades diferenciadas, observamos, através da aplicação 
de questionários, que, ao descreverem suas experiências com a matemática enquanto estudantes, os participantes destacaram como foram marcantes as aulas em que seus professores inseriram elementos diferentes dos tradicionais, como dinâmicas, jogos e realização de atividades em espaços físicos diferentes do da sala de aula. Ademais, lembram-se com desagrado da não utilização desses elementos, que consideram ser facilitadores para a aprendizagem.

É necessário pontuar que o perfil desses participantes é, do ponto de vista acadêmico, diferenciado do perfil de professores de Matemática que, no geral, compõem o quadro de docentes da Educação Básica, uma vez que todos os professores concluíram ou estão em processo de conclusão de um curso de mestrado. Segundo dados do INEP(2007), a maioria dos professores da Educação Básica possuem o curso de licenciatura. No entanto, ainda é pequeno percentual de mestres. Outro diferencial do grupo, ainda relacionado ao curso de mestrado, é a oportunidade do contato com os temas relacionados com pesquisa em ensino de Matemática, haja vista que encontram-se em momentos de produção acadêmica.

Feitas as devidas considerações, selecionamos algumas sugestões para as dificuldades encontradas com relação à aplicação das atividades, entre elas, foi proposto a divisão e organização da turma em grupos menores, com no máximo 10 estudantes, escolhendo entre eles dois estudantes: um que ficaria responsável pela mediação da atividade, colocando-se na condição de "juiz", cuidando para que as regras sejam cumpridas; o outro estudante seria responsável pela organização e cuidados com o material. Também foi sugerido a execução de atividades simultâneas e até mesmo no formato de gincana, envolvendo os outros professores da escola, que poderiam auxiliar não só com o próprio trabalho, mas também fornecendo materiais relativos às suas disciplinas e que poderiam ser utilizados na construção e/ou desenvolvimento das atividades.

Os professores apontaram que colocar os estudantes como organizadores das atividades, pode ser mais uma estratégia para que eles participem mais ativamente do processo de aprendizagem, deixando de ser apenas observadores e passando a compor a própria atividade, despertando o interesse e tornando a aprendizagem mais prazerosa.

Um dos professores expressou, através do questionário, que a matemática "parecia desconfortável" para a maioria dos estudantes, especialmente pelo caráter abstrato e pela ausência de processos de experimentação nas aulas. Consoante a essa constatação, Hartmann(2014) afirma que,

[...]o aluno de hoje quer aprender, é sedento pelo conhecimento, mas não tem paciência de assistir aulas monótonas, sem atrativos. Ele quer ser o descobridor do conhecimento. Quer ser autônomo e ter capacidade de agir por si só, contando, obviamente, com a orientação do professor, que também tem papel fundamental como facilitador do processo. (p.64). 32 ] 
Atender as necessidades dos estudantes no mundo atual não é uma tarefa simples. Afinal, esse trabalho demanda uma formação profissional que ofereça, além de conteúdos, recursos metodológicos capazes de transformá-los em aprendizagens. Dessa forma, questionamos se os cursos de licenciatura e pós-graduação em Matemática têm contemplado conteúdo e ensino de forma equitativa ou se tem enfatizado um desses aspectos em detrimento dos outros. Não obstante, cabe indagar se, ao longo do processo de formação acadêmica, esses professores estão sendo instrumentalizados para atender as demandas desse novo perfil de alunos.

As licenciaturas em matemática, de certa forma, ainda encontram-se perpassadas por uma ideologia de ensino tradicional. Assim, o estudante é avaliado exclusivamente pelo seu conhecimento a respeito dos conteúdos matemáticos, desconsiderandose, desse modo, os aspectos pedagógicos indispensáveis à sua formação enquanto profissional de educação. Uma das causas dessa negligência quanto ao conteúdos de caráter pedagógico é que a maioria dos professores dos cursos de nível superior não teve contato com a Educação Básica e, tampouco, atuaram como professores do Ensino Fundamental. Consequentemente, não se apropriaram amplamente da realidade e das necessidades desses futuros profissionais da educação que estão sendo formados.

Quando se trata dos conteúdos algébricos, observamos, a partir das respostas dos participantes nos questionários, que, enquanto estudantes, consideraram esses conteúdos desafiadores e repletos de manipulações com regras, utilizando, para expressarem suas impressões relativas à álgebra, expressões como "um jogo de números, com suas próprias regras", "caminho para resolver problemas" e "a álgebra era processo de repetição".

Apenas dois dos professores participantes analisaram esses conteúdos como sendo fáceis, dizendo: "era a minha parte preferida, parecia mais confortável" e "é a parte que eu mais gosto". Contudo, ao serem indagados sobre o ensino desses conteúdos, os professores apresentaram alguns embaraços, reforçando a ideia de que apenas o conhecimento algébrico não é suficiente para garantir o ensino. Nesse sentido, os conhecimentos necessários para o ensino de matemática envolvem conhecimento do conteúdo, das habilidades que o envolvem, dos conteúdos que antecedem e precedem o atual, do grupo para o qual irá ensinar e por último, das metodologias de ensino que visam garantir a aprendizagem (BALL et al. apud RIBEIRO, 2015, p. 50).

Os professores são, portanto, os responsáveis pelo elo entre conteúdo e ensino, e ainda, podem ser, além de mediadores, facilitadores no processo de aprendizagem dos estudantes. A partir dos conhecimentos enumerados acima, os professores têm condições de selecionar, criar ou adaptar e decidir sobre as propostas de ensino que lhe são apresentadas cotidianamente, assim como fizeram com as propostas desse trabalho. 
Percebemos que os participantes em todas as atividades, além de darem sugestões sobre o material exposto e a forma de organização, discutiram as possibilidades de conteúdos a serem abordados, algumas variações para as atividades e propuseram inclusão e exclusão de etapas e formas de registro e avaliação. Ademais, em vários momentos, reconstruíram as atividades, adaptando-as às realidades vivenciadas como professores da Educação Básica, constituindo, dessa forma, o processo de validação.

Assim, no que diz respeito à atividade Trilha das Leis,os professores propuseram alterações nas cartas e registro, explorando com os estudantes a ideia do desconhecido e a introdução da linguagem formal algébrica como forma de representar as leis contidas nas cartas. Um dos participantes propôs inclusive que nas cartas contivessem tanto leis escritas na língua natural, quanto leis escritas de forma algébrica, visando facilitar o acesso e apropriação da linguagem e simbolismos algébricos.

Entre as principais dificuldades apontadas pelos professores relacionadas à aprendizagem de álgebra estão o processo de transição da aritmética para a álgebra e a transcrição da linguagem natural para a linguagem algébrica. Nesse sentido, a proposta desse trabalho contribuiu para que o professor conhecesse instrumentos capazes de explorar a compreensão da ideia de variável e de apropriação da linguagem algébrica.

Na realidade do contexto escolar, Linz e Gimenez(1997 apud TELES, 2004) afirmam que

álgebra e aritmética são definidas em função dos conteúdos que tratam: coisas da álgebra são equações, inequações, funções e etc., e as da aritmética são números, operações, tabuada etc. (p.10).

Para Souza e Diniz(1996) a principal diferença entre a aritmética e a álgebra consiste no falto de que a aritmética é utilizada para resolver operações e problemas que envolvem um valor exato, enquanto a álgebra consiste na busca por elementos genéricos, cheios de representatividade e despreocupados quanto à quantidade (valores exatos). Para Booth (1995 apud TELES, 2004), as possíveis dificuldades encontradas pelas crianças na aprendizagem de álgebra podem estar relacionadas à essa dicotomia entre conteúdos algébricos e aritméticos, visto que

A álgebra não é isolada da aritmética; sendo ela, em muitos aspectos, a "aritmética generalizada", apontando nisto uma das fontes de dificuldade. Para compreender a generalização das relações e procedimentos aritméticos é preciso primeiro que tais relações e procedimentos sejam apreendidos dentro do contexto aritmético. Se não forem reconhecidos ou se os alunos tiverem concepções erradas a respeito deles, seu desempenho em álgebra poderá ser afetado. Neste caso, algumas dificuldades que o aluno tem em álgebra não são tanto de álgebra propriamente dita, mas de dificuldades conceituais em aritmética que não foram corrigidos. (p.14). 
Logo, é possível perceber, mais uma vez, a importância do conhecimento aritmético para o desenvolvimento e aprendizagem de álgebra. Nesse sentido, os professores participantes apontam que as atividades constituem uma importante forma de reforçar os cálculos aritméticos. Em vários momentos, torna-se necessário a realização de cálculos mentais visando garantir um melhor desempenho durante o desenvolvimento da atividade. Os professores ainda enumeram algumas multiplicações menos compreendidas pelos estudantes (multiplicações por seis, sete e oito), ponderando que há necessidade de reforçá-las durante todo o Ensino Fundamental Anos Finais e sugerem que as mesmas sejam utilizadas como cartas do jogo Trilha das Leis, proporcionando aos estudantes compreender o conteúdo de forma mais prazerosa.

A segunda categoria a validação das atividades de ensino e aprendizagem discute os aspectos diretamente ligados à produção e à utilização do material desenvolvido para a aplicação das atividades. Vale destacar novamente o entrelaçamento das categorias, uma vez que as mudanças nas atividades têm suas raízes e consequências no processo de ensino e aprendizagem de álgebra.

Os professores consideraram que os estudantes teriam dificuldades para preencher o registro da atividade trilha das leis, caso não tivessem conhecimento da linguagem algébrica. Por conseguinte, apontaram que o registro seria interessante para turmas de $7^{\circ}$ e $8^{\circ}$ ano que já têm conhecimentos algébricos e que seriam necessárias adaptações para que o mesmo registro fosse utilizado por estudantes que estão iniciando os estudos de álgebra. Uma das possíveis soluções seria o uso da oralidade, ficando o professor responsável por instigar os estudantes a construírem formas de representação simbólicas com vistas à formalização da linguagem e escrita algébricas.

Nesse contexto, no tocante às possíveis dificuldades relativas ao equacionamento Cotret (1997 apud RIBEIRO, 2012), aponta que

[...]a pertinência e a adequação das equações que são usadas para modelar problemas intra e extra Matemática. Reconhece que, muitas vezes, não sabemos justificar a escolha de um determinado modelo de equação para representar certo problema, a não ser pela resolução e pela busca da resposta do problema. Afirma que as pessoas não sabem justificar o porquê de terem escolhido tal modelo, nem têm certeza de ser esse modelo o mais eficaz naquela situação, a menos que recorram à resolução da equação. (p.1). [57]

Contudo, observamos que as dificuldades dos professores com relação ao conceito e à utilização da álgebra e de outros conteúdos matemáticos podem influenciar na elaboração de conceitos por parte dos estudantes. Ribeiro(2012) aponta algumas pesquisas nas quais os professores apresentaram dificuldades ao conceituar equações, mantendo uma visão limitada de que são manipulações puramente técnicas para se encontrar um valor desconhecido. Esse autor destaca que 
[...]os professores precisam saber para ensinar, mas envolve, também, o que os professores, eles mesmos, precisam saber e ser capazes de fazer para realizar tal ensino. Nesse mesmo sentido, ressaltam a necessidade de os professores serem capazes de explicar o significado de conceitos e procedimentos (por exemplo, algoritmo da subtração e conceito de subtração) aos estudantes e de escolher exemplos e situações que sejam adequados para tal desenvolvimento. (p.1) [57]

Desse modo, observamos que os professores são protagonistas no processo de ensino, pois são eles os responsáveis por selecionarem e desenvolverem os conteúdos e atividades nas salas de aula a partir dos seus conhecimentos a respeito desses conteúdos, da turma, das metodologias e dos recursos para o ensino adequando e adaptando convenientemente.

Ainda sobre os registros, os professores participantes consideraram que, para as atividades Trilha das Leis e Batalhava Naval, seria interessante construí-las com a turma partindo da oralidade para se chegar à formalização e escrita. Os docentes sugeriram que, ao final da atividade, o professor discutisse as representações construídas pelos grupos, incitando os estudantes e mostrando exemplos no quadro, facilitando a compreensão e a apropriação de conceitos pela turma.

Os participantes se sentiram atraídos e demonstraram apreço pelo designer do material, gostaram das cores e afirmaram que são simples de serem construídos e que o custo não é alto. Todavia, propuseram sugestões quanto à utilização de materiais recicláveis para a construção. Sugeriram fazer os pinos de boliche com garrafas pet e areia, a utilização de bolas de esporte para realização das jogadas ou, ainda, no caso de reformulação da atividade, que os estudantes pudessem utilizar pilhas contendo latas de refrigerante e bolas de tênis.

Os professores participantes também avaliaram os tabuleiros e foram unânimes ao considerarem insuficientes a quantidade de casas do tabuleiro da atividade Trilha das Leis e sugeriram aumentá-las, inclusive numerando-as de forma que fosse possível facilitar a contagem das casas. No campo de batalha da Batalha Naval, os professores acharam importante que as letras ficassem na parte inferior (debaixo) do campo, pois auxiliaria na associação para a futura aprendizagem de coordenadas no plano cartesiano.

Os professores ainda consideraram que as embarcações que ocupam apenas uma coordenada no campo de batalha devem ser retiradas, já que são escolhidas aleatoriamente, não contribuindo para que o estudante desenvolva estratégias que permitam acertar o ponto desejado (predefinido).

Os professores demonstraram apreço pelas atividades e, em vários momentos afirmaram que elas cumprem a proposta de ensinar expressões algébricas. No entanto, surgiram várias sugestões, uma vez que os mesmos perceberam nessas atividades pro- 
postas, possíveis adaptações para inúmeros conteúdos matemáticos. Logo, foi considerado que a atividade Batalha Naval pode ser uma aliada no estudo de coordenadas no plano cartesiano e ainda no estudo de simetria. Reforçando essa ideia de adaptação das atividades para explorar outros conteúdos, citamos o professor P1 que propôs duas atividades criadas a partir da Batalha Naval para trabalhar os conteúdos "Números inteiros na reta numérica" e ainda "Potência e raiz quadrada". Essas atividades estão em anexo no fim desse trabalho.

\subsection{Considerações Finais}

O ensino em qualquer área exige constante formação por parte dos profissionais, as realidades e contextos modificam-se ao longo dos anos, exigindo reformulações e adaptações que permitam atender o público para o qual se ensina. Afinal, entendemos que formar não significa apenas repassar os conteúdos aos estudantes, mas partir das próprias experiências desses estudantes, adquiridas por meio de suas vivências, entrelaçando-as aos conteúdos curriculares, a fim de contribuir para esses constituam-se ativamente dentro da sociedade.

Os conteúdos matemáticos do Ensino Fundamental, em alguns casos, permitem esse entrelaçamento por serem conteúdos aplicáveis a contextos reais. No entanto, muitas vezes, quando esses conteúdos são ensinados em sala de aula, não se cria esse elo, e os princípios de conhecimento que os estudantes já carregam a respeito de um determinado conceito matemático não é utilizado como base para fundamentar a elaboração e a aquisição de novos conceitos. Nesse sentido, a Matemática, por vezes, acaba sendo vista como formal e inacessível e não como mais um instrumento capaz de contribuir para a formação intelectual e construção de saberes, além de apresentar-se como ferramenta para solução de muitas situações-problemas próximas aos contextos reais.

Nesse contexto, o ensino de álgebra apresenta-se como desafio para o professor, visto que os estudantes constroem expectativas à respeito desses conteúdos que despertam a curiosidade em conhecer e aprender, principalmente sobre equações. É comum que os estudantes de sétimo ano fiquem ansiosos para esse momento de aprender "contas com letras". Os professores têm, assim, uma ótima oportunidade de incitar os estudantes a apreciarem o conhecimento algébrico, despertando neles o gosto em aprender e construir a álgebra e a matemática como um todo.

O papel do professor é fundamental para garantir que o estudante não apenas "receba" o conhecimento, mas que faça parte desse momento de construção. O professor é quem, a partir de seus conhecimentos de matemática, do ensino e dos estudantes, 
irá optar por quais instrumentos irá utilizar para tornar o conhecimento acessível aos alunos. Logo, há uma preocupação com a formação do professor, que assim como os estudantes, necessita permanecer em constante aprendizagem buscando trocar experiências, conhecer novas metodologias que permitam discutir e propor ações que se apontam como soluções para os desafios que surgem a partir do ensino.

As licenciaturas e pós-graduações em matemática tendem a uma preocupação excessiva com os conteúdos e, em alguns casos, acabam menosprezando o ensino e a prática em sala de aula. As poucas disciplinas relacionadas ao ensino e o curto tempo de estágio, geralmente, não promovem de maneira adequada a aproximação entre teoria e prática. Soma-se a isso o fato de que em alguns momentos, os estágios nas licenciaturas são voltados apenas para observação e avaliação do professor regente, como se o estagiário tivesse a obrigação de fazer um julgamento daquele professor e não uma valorização e aprendizagem a partir dos conhecimentos que aquele docente pode oferecer ao futuro licenciado.

Os cursos de pós graduação, de modo geral, são procurados por professores que buscam complementação para sua formação profissional. O curso de mestrado PROFMAT tem foco na formação do professor de matemática do Ensino Básico da escola pública e "ênfase no domínio aprofundado de conteúdo matemático relevante para sua formação docente". Contudo, questionamos se a ênfase no conteúdo matemático que, nesse caso, se aponta como solução para causar "impacto substantivo" na formação do professor seria de fato a maior emergência desse professor de matemática na atualidade.

Obviamente, não pretendemos minimizar a importância do conhecimento matemático na formação docente. Entretanto, é preciso atentar-se para as necessidades dos próprios educadores, para que os mesmos, a partir de suas experiências e vivências em sala de aula, apontem os princípios que devem ser observados e contemplados nos cursos de formação.

Desde a elaboração dessa proposta de pesquisa, surgiram inquietações que permitiram refletir sobre as necessidades mais emergentes dos professores atuantes na Educação Básica. Nesse sentido, consideramos fundamental a participação dos professores e pretendemos destacar suas percepções a respeito do ensino e aprendizagem de álgebra, pois são dotadas de experiências que permitem entrelaçar conhecimento matemático, teorias de aprendizagem e prática pedagógica, constituindo-se em um significativo material que pode apresentar-se como sugestão para os profissionais de matemática e outras áreas, fragmentar-se em outros processos de investigação, ou ainda, subsidiar posteriores trabalhos que se aproximam dessa pesquisa. 


\section{Referências Bibliográficas}

[1] ACHEGaUA SAlazAR. G. de A. Tornando-me Professora: uma experiência vivida no clube de matemática.. Monografia - Especialização em Educação Matemática. Instituto de Matemática e Estatística. Universidade Federal de Goiás. Goiânia. 2013.

[2] ACHEGAUA SAlazAR. G. de A. In: Wellington Lima Cedro. (Org.) A corrida de sacos e os números negativos: reflexões de uma professora.. Clube de Matemática: vivências, experiências e reflexões. 1ed.Curitiva: CRV, 2015, v., p. $55-62$.

[3] ANDRADE L. C. C. de. Jogos estratégicos no ensino de matemática - refletir, implementar e avaliar. Anais do VI Congresso de Pesquisa, Ensino e Extensão. Goiânia, Goiás. 2009. p. 5473- 5477. Disponível em http://projetos.extras.ufg.br/conpeex/2009/artigos/prolicen/prolicen.pdf. Acesso em: 06 junho 2016.

[4] ARAujO, M. de L. H. S. Avaliação Internacional: Concepções inerentes ao PISA e seus resultados no Brasil. Programa de Pós-graduação em Ensino, Filosofia e História das Ciências (UFBA/UEFS). Trabalho apresentado no XXVI Simpósio Brasileiro de Política e Administração da Educação. Recife, PE. Disponível em: http://www.anpae.org.br/simposio26/1comunicacoes/MaLourdesAraujoComunicacaoOral-int.pdf. Acesso em: 06 junho 2016.

[5] BACCARIN, S. A. de O. Investigação Matemática: Uma análise da sua contribuição na construção de conceitos algébricos. Dissertação de Mestrado, Universidade de Brasília, Brasília, 2008.

[6] BALDinO, R. R. Assimilação Solidária. Grupo de Pesquisa-Ação em Educação Matemática da UNESP, Rio Claro (GPA). UNESP, Campus de Rio Claro - SP. Dis- 
ponível em: midiaindependente.org/media/2004/06/282677.doc. Acesso em: 27 maio 2016. 30

[7] BARDIN L. L'Analyse de contenu. Editora: Presses Universitaires de France, 1977. apud SILVA, A. H. et al. Análise de conteúdo: fazemos o que dizemos? Um levantamento de estudos que dizem adotar a técnica. IV Encontro de Ensino e Pesquisa em Administração e Contabilidade, Brasília, DF, 2013.

[8] BARDin, L. Análise de conteúdo. São Paulo: Edições 70, 2011, 229 p. apud COSTA, I.L. As concepções e práticas avaliativas em Matemática de um grupo de professores do $5^{\circ}$ ano do Ensino Fundamental e suas relações com a Prova Brasil . Dissertação Mestrado - Faculdade de Educação - Universidade de Brasília. Brasília, 2015.

[9] BOAVIDA, A M. \& PONTE, J. P. Investigação colaborativa: Potencialidades e problemas. In GTI (Org), Reflectir e investigar sobre a prática profissional. Lisboa: APM, 2002. (p. 43-55) 68

[10] BOMFIM, E. M. ; MANGUEIRA, M. O pensamento representacional e sua atualização nas ciências humanas.. Psicologia \& Sociedade, 24(1), 15-22. 33. 34

[11] BORBA, M. de C. Pesquisa Qualitativa em Educação Matemática. Belo Horizonte: Autêntica, 2004. 120p.

[12] BRASIL (País), Secretaria de Educação Fundamental. Parâmetros curriculares nacionais : Matemática Secretaria de Educação Fundamental. Brasília : MEC / SEF, 1998. 148 p. 31

[13] BRASIL. Secretaria de Educação Fundamental. Parâmetros curriculares nacionais : matemática. Secretaria de Educação Fundamental. Brasília : MEC/SEF, 1997. 142p. 87

[14] BULGRAEN, V.C. O papel do professor e sua mediação nos processos de elaboração do conhecimento. Revista Conteúdo, Capivari, v.1, n.4, ago./dez. 2010. ISSN 1807-9539. pg. 30-38. 51

[15] Caldas, R.F.L e Hubner, M.M.C. O desencantamento com o aprender na escola: o que dizem professores e alunos. Psicologia: Teoria e Prática, 2001. p. 71-82. apud JESUS, A.G; NUNES, C.; FERREIRA A.C.; A motivação do aluno para aprender Matemática no $9^{\circ}$ ano do Ensino Fundamental. XIII CIAEM-IACME, Recife, Brasil, 2011. Disponível em: 
http://www.repositorio.ufop.br/bitstream/123456789/1287/1/EVENTO_Motiva \%C3\%A7\%C3\%A3oAlunoAprender.pdf. Acesso em: 06 junho 2016.

[16] CEDRO, W.L. O espaço de aprendizagem e o ensino: O Clube de Matemática. Dissertação de Mestrado, Faculdade de Educação da Universidade de São Paulo. São Paulo, 2004. 12, 53

[17] CEDRO, W.L. Clube de Matemática: vivências, experiências e reflexões. Curitiba, PR: CRV, 2015. 55

[18] CEDRO, W.L. Clube de matemática. Projeto de Extensão. http://lattes.cnpq.br/1123884255260078. Acesso em: 07 março 2016.

[19] COSTA, I.L. As concepções e práticas avaliativas em Matemática de um grupo de professores do $5^{\circ}$ ano do Ensino Fundamental e suas relações com a Prova Brasil . Dissertação Mestrado - Faculdade de Educação - Universidade de Brasília. Brasília, 2015. 76

[20] DANTE, L.R. Projeto Teláris : matemática : ensino fundamental 2. 2.ed. São Paulo: Ática, 2015. 44

[21] DUVAL, R. Registros de Representações Semióticas e Funcionamento Cognitivo da Compreensão em Matemática. In: MACHADO, Ślvia Dias Alcântara. (Org). Aprendizagem em matemática: registros de representação semiótica. Campinas, SP: Papirus, 2003. p. 11- 33.

[22] FÁVERO, M. H., \& PINA NEVES, R. S. A docência universitária como locus de pesquisa da psicologia do desenvolvimento adulto. Revista Semestral da Associação Brasileira de Psicologia Escolar e Educacional, SP. Volume 17, Número 2, Julho/Dezembro de 2013: 319-328.

[23] FERNANDES, M. da C. V. A inserção e vivência da mulher na docência de matemática: uma questão de gênero. Dissertação de Mestrado apresentada ao programa de Pós-graduação em Educação(PPGE), Universidade Federal da Paraíba (UFPB). João Pessoa, Paraíba, 2006. 83

[24] FERREIRA, D.A. et al. Indisciplina e desinteresse do aluno da rede oficial de ensino: uma abordagem da sociologia da educação. 2007. apud JESUS, A.G; NUNES, C.; FERREIRA A.C.; A motivação do aluno para aprender Matemática no $9^{\circ}$ ano do Ensino Fundamental. XIII CIAEM-IACME, Recife, Brasil, 2011. Disponível em: 
http://www.repositorio.ufop.br/bitstream/123456789/1287/1/EVENTO_Motiva \%C3\%A7\%C3\%A3oAlunoAprender.pdf. Acesso em: 06 junho 2016.

[25] FIORENTINI, D. Pesquisar práticas colaborativas ou pesquisar colaborativamente? In: Pesquisa Qualitativa em Educação Matemática. Belo Horizonte: Autêntica, 2004, p. 47-76. 68

[26] FREITAG, B.; COSTA, W. F.; MOTTA, V. O livro didático em questão. 3.ed. São Paulo: Cortez, 1997. 40

[27] FROTA, M. C. R. Experiência Matemática e Investigação Matemática. V CIBEM. Porto. Portugal. 2005. 51

[28] GIL, K.H. Reflexões sobre as dificuldades dos alunos na aprendizagem de álgebra. Dissertação de Mestrado, Mestrado em Educação em Ciências e Matemática, Faculdade de Física, PUCRS. Porto Alegre, 2008. 11, 29

[29] GODOY, E.V. ; SANTOS, V. M. O cenário do ensino de Matemática e o debate sobre o currículo de matemática. Práxis Educacional, Vitória da Conquista, BA, v. 8, n. 13 p. 253-280 jul./dez. 2012.

[30] GRANDO, R.C.A. O Jogo e suas Possibilidades Metodológicas no Processo Ensino-Aprendizagem da Matemática. Dissertação de Mestrado, Universidade Estadual de Campinas, Campinas, SP, 1995.

[31] GRANDO, R.C.A. O Conhecimento Matemático e o Uso de Jogos na Sala de Aula. Tese de doutorado, Universidade de Campinas, Campinas, SP, 2000. 7

[32] HARTMAnN, A. O Desporto Orientação como Ferramenta para o Ensino da Matemática. Dissertação de Mestrado, Departamento de Matemática, Universidade de Brasília, Brasília, DF, 2014. 111

[33] INEP. Instituto Nacional de Estudos e Pesquisas Educacionais Anísio Teixeira. Sinopse Estatística da Educação Básica 2015. Brasília: Inep, 2016. Disponível em: http://portal.inep.gov.br/basica-censo-escolar-sinopse-sinopse. Acesso em: 24 junho 2016. 22, 82

[34] KAPUT, J.J. A Research Base Supporting Long Term Algebra Reform?. In: Annual meeting of north american chapter of the international group for the psychology of mathematics education, 17. Columbs, 1995. Disponível em: http://eric.ed.gov/PDFS/ED389539.pdf. Acesso em: 28 fevereiro 2016. 
[35] KIERAN, C. The core of Algebra: Reflections on its Main Activities.. In: STACEY,K.; CHICK, H.; KENDAL,M. (Eds.). The Future of the Teaching and Learning of Algebra: The 12th ICMI Study. Dordrecht: Kluwer, 2004. p. 21-33.

[36] LEONTIEV, A. N. O desenvolvimento do psiquismo. Lisboa: Livros Horizonte, 1978. 51

[37] LIBÂNEO, J. C. Didática. 1. ed. São Paulo: Cortez, 1994. apud BULGRAEN, V.C. O papel do professor e sua mediação nos processos de elaboração do conhecimento. Revista Conteúdo, Capivari, v.1, n.4, ago./dez. 2010. ISSN 1807-9539. pg. 30-38. 51

[38] LIMA, R. N. Equações Algébricas no Ensino Médio: uma jornada por diferentes mundos da Matemática. Tese (Doutorado em Educação Matemática). Pontifícia Universidade Católica de São Paulo, São Paulo, 2007. 90

[39] LORENZATO, S. O laboratório de ensino de matemática na formação de professores. Campinas, SP: Autores associados, 2006. Coleção formação de professores. 6

[40] LOREnZATO, S. Para aprender Matemática. 2. ed. rev. Campinas: Autores Associados, 2008. Coleção Formação de Professores.

[41] MACHADO A. A. R. A confecção e validação de jogos para o ensino de geometria no ensino médio: um desafio na formação de professores. Anais do XI Encontro Nacional de Educação Matemática ? ISSN 2178-034X. Curitiba, Paraná, 2013. 69

[42] MALTA, I. Sobre um Método não Tradicional para Aprender Cálculo. In: CARVAlHO, L. M.; GUIMARÃES, L. C. (org.). História e Tecnologia no Ensino de Matemática. vol 1. Rio de Janeiro: IME - UERJ, 2002. apud GIL, K.H. Reflexões sobre as dificuldades dos alunos na aprendizagem de álgebra. Dissertação de Mestrado, Mestrado em Educação em Ciências e Matemática, Faculdade de Física, PUCRS. Porto Alegre, 2008.

[43] MARinhO-ARAujO, C. M.; RABELO, M. L. Avaliação educacional: a abordagem por competências. Avaliação: Revista da Avaliação da Educação Superior, vol. 20, núm. 2, julio, 2015, pp. 20

[44] MELO, M. C. H. de; CRUZ, G. de C. Roda de conversa: uma proposta metodológica para a construção de um espaço de diálogo no Ensino Médio. Imagens da Educação, v. 4, n. 2, p. 31-39, 2014. Disponível em: 
http://periodicos.uem.br/ojs/index.php/ImagensEduc/article/view/22222 acesso em 10 julho 2016. 79

[45] MONTEIRO, M. S. Introdução à Análise Real. Notas de Aula, Instituto de Matemática e Estatística da Universidade de São Paulo - SP. 2014. Disponível em: http://www.ime.usp.br/ martha/mat0315/aulas1a10.pdf. Acesso em: 30 maio 2016. 14

[46] MOURA, M. A construção do signo numérico em situação de ensino. Tese (Doutorado em Educação) - Faculdade de Educação - Universidade de São Paulo, São Paulo, 1992.

[47] MOURA, M. A atividade de ensino como unidade formadora. Bolema, vol. 2, n.12, pp. 29-43, Rio Claro, 1996. 52, 54

[48] MOYSÉS, L. Aplicações de Vygotsky à Educação Matemática. Ed. Papirus, $7^{\mathrm{a}}$ edição. São Paulo, 2006.

[49] OLIVEIRA, D.C. de. Indícios de apropriação dos nexos conceituais da álgebra simbólica por estudantes do Clube de Matemática. Dissertação de mestrado Universidade Federal de Goiás, Mestrado em Educação em Ciências e Matemática, Goiânia, Goiás, 2014.

[50] OliveirA, E. de; ENS, R. de T.; ANDRADE, D. B. S. F.; MUSSIS, C. R. Análise de conteúdo e pesquisa na área da educação. Revista Diálogo Educacional, Curitiba, v. 4, n.9, p.11-27, maio/ago. 2003. 81

[51] PIMENTA, S. G., Garrido, E., MOURA, M. Pesquisa colaborativa na escola facilitando o desenvolvimento profissional de professores. In: REUNIÃO ANUAL DA ANPED, 24., Caxambu. Anais... Caxambu, MG. 68

[52] PINA NEVES, R. da S. A formação de conceitos geométricos no contexto dos projetos de trabalho mediada pelo CABRI GÉOMĖTRE. Dissertação de Mestrado, Universidade de Brasília, Brasília, 2002.

[53] PINA NEVES, R. da S. A divisão e os Números Racionais: uma pesquisa de intervenção psicopedagógica sobre o desenvolvimento de competências conceituais de alunos e professores. Tese de doutorado, Universidade de Brasília, Brasília, 2008.

[54] POWELL, A.B. Métodos de pesquisa em educação matemática usando escrita, vídeo e internet.Campinas, SP: Mercado de Letras,2015. (Coleção Educação Matemática). 71, 72 
[55] RIBEIRO, A.J Álgebra a formação do professor: explorando os conceitos de equação e de função. Belo Horizonte: Autêntica (2015). 20, 35, 88

[56] RIBEIRO, A.J Conhecimento matemático para o ensino de equação: algumas implicações para a formação do professor de matemática. V SEMINÁRIO INTERNACIONAL DE PESQUISA EM EDUCAÇÃO MATEMÁTICA. Petrópolis, Rio de janeiro, Brasil, 2012. 88

[57] RIBEIRO, A.J Equação e conhecimento matemático para o ensino: relações e potencialidades para a Educação Matemática. Bolema vol.26 $\mathrm{n}^{\mathrm{o}}$. 42B Rio Claro abr. 2012. Disponível em: http://dx.doi.org/10.1590/S0103636X2012000200007. Acesso em: 14 julho 2016. 114, 115

[58] SENOS, J. e DINIZ, T. Auto-estima, resultados escolares e indisciplina: estudo exploratório numa mostra de adolescentes. Analise psicológica, 2(XVI), 1998. p. 267-276. apud JESUS, A.G; NUNES, C.; FERREIRA A.C.; A motivação do aluno para aprender Matemática no $9^{\circ}$ ano do Ensino Fundamental. XIII CIAEM-IACME, Recife, Brasil, 2011. Disponível em: http://www.repositorio.ufop.br/bitstream/123456789/1287/1/EVENTO_Motiva \%C3\%A7\%C3\%A3oAlunoAprender.pdf. Acesso em: 06 junho 2016.

[59] SILVA, A.J.N. da. Formação lúdica do futuro professor de matemática por meio do laboratório de ensino. Dissertação de Mestrado, Universidade de Brasília, Faculdade de Educação, Programa de Pós Graduação em Educação, Brasília, DF, 2014.

[60] SILVA, D. A. Clube de matemática: palco de transformação dos motivos da atividade de estudo. Dissertação de Mestrado, Programa de Pós-Graduação em Educação em Ciências e Matemática. Universidade Federal de Goiás. Goiânia, Goiás, 2014.

[61] SILVA, A. H. et al. Análise de conteúdo: fazemos o que dizemos? Um levantamento de estudos que dizem adotar a técnica. IV Encontro de Ensino e Pesquisa em Administração e Contabilidade, Brasília, DF, 2013. Disponível em http://www.anpad.org.br/diversos/trabalhos/EnEPQ/enepq_2013/2013_EnEPQ 76.pdf. Acesso em: 20 junho 2016. 80

[62] SILVA, S. de C. R. da; SCHIRLO, A. C. Teoria da aprendizagem significativa de Ausubel: reflexões para o ensino de física ante a nova realidade social. Imagens da Educação, v. 4, n. 1, p. 36-42, 2014. 86 
[63] SMITH, E. Representational Thinking as a Framework for Introducing Functions in the Elementary Curriculum. In: KAPUT,J.; CARRAHER,D.; BLANTON,M.L. (Eds.) Álgebra in the Early Grades. New York: Lawrence Erlbaum Associates, 2008. p.133-160.

[64] SOUZA, E. R; DINIZ, M. I. S. V. Álgebra: das variáveis às equações e funções. 2 ed. São Paulo: IME-USP, 1996. 111 p.

[65] TALL, D.; VINNER, S. Concept image and concept definition in mathematics, with special reference to limits and continuity, Educational Studies in Mathematics, Dordrecht, vol. 3, n. 12, p. 151-169, 1981. apud RIBEIRO, A.J Álgebra a formação do professor: explorando os conceitos de equação e de função. Belo Horizonte: Autêntica (2015).

[66] TARDIF, M. Saberes docentes e formação profissional. Petrópolis, Rio de Janeiro, Vozes, 2002.

[67] TASSONI, E.C.M. Afetividade e aprendizagem: a relação professor aluno. 2000. apud JESUS, A.G; NUNES, C.; FERREIRA A.C.; A motivação do aluno para aprender Matemática no $9^{\circ}$ ano do Ensino Fundamental. XIII CIAEM-IACME, Recife, Brasil, 2011. Disponível em: http://www.repositorio.ufop.br/bitstream/123456789/1287/1/EVENTO_Motiva \%C3\%A7\%C3\%A3oAlunoAprender.pdf. Acesso em: 06 junho 2016.

[68] TEIXEIRA, S.F. de A. Uma reflexão sobre a ambiguidade do conceito de jogo na educação matemática.Dissertação de Mestrado, Universidade de São Paulo, São Paulo, 2008.

[69] TELES, R. A. de M. A aritmética e a álgebra na matemática escolar. Educação Matemática em Revista. no 16. Ano 11. maio 2004. p.8-15.

[70] TONET, I. Educação e formação humana. In: JIMENEZ, Susana, et al (Orgs.) Marxismo, educação e luta de classes. Fortaleza: UECE/IMO/SINTSEF, 2008. apud SILVA, A.J.N. da, Formação lúdica do futuro professor de matemática por meio do laboratório de ensino. Dissertação de Mestrado, Universidade de Brasília, Faculdade de Educação, Programa de Pós Graduação em Educação, Brasília, DF, 2014. 10 
Apêndice A

Apêndice 


\section{Identificação}

1. Sexo: Masculino $\square$ Feminino

2. Data do seu nascimento:

3. Formação (graduação em?):

4. Instituição em que cursou a graduação:

5. Local de trabalho:

Nome da instuição:

Endereço:

6. Cargo:

7. Descrição resumida do cargo:

8. No seu cargo você trabalha com ( ) alunos(as) da Educação Infantil; ( ) alunos (as) do Ensino Fundamental, Anos Iniciais; ( ) alunos (as) do Ensino Fundamental, Anos Finais; ( ) a direção; ( ) os professores e professoras da Educação Infantil; ( ) os professores e professoras do Ensino Fundamental, Anos Iniciais; ( ) os professores e professoras do Ensino Fundamental, Anos Finais; ( ) os professores e professoras do Ensino Médio; ( ) pais de alunos; ( ) alunos com dificuldades de aprendizagem; ( ) sala de recursos; ( ) outros.

Você pode marcar mais e uma opção. Caso assinalou outros, por favor, descreva a atividade.

Figura A.1: Questionário de identifição dos participantes - Parte 1 
1. Na minha história escolar a matemática...

2. Na minha história escolar a álgebra...

3. No meu percurso profissional - como professor(a) de matemática - a álgebra

Figura A.2: Questionário de identifição dos participantes - Parte 2 


\section{TERMO DE CONSENTIMENTO LIVRE E ESCLARECIDO}

Você está sendo convidado(a) a participar, como voluntário(a), da pesquisa "Expressões algébricas no Ensino Fundamental Anos Finais: A validação de atividades de ensino junto à estudantes e professores. " -, no caso de você concordar em participar, favor assinar ao final do documento. Sua participação não é obrigatória, e, a qualquer momento, você poderá desistir de participar e retirar seu consentimento. Sua recusa não trará nenhum prejuízo em sua relação com a pesquisadora ou com a instituição.

Você receberá uma cópia deste termo onde consta o telefone e endereço da pesquisadora, podendo tirar dúvidas do projeto e de sua participação sempre que avaliar conveniente.

Pesquisadora responsável: Ludimila Cássia Coelho de Andrade

\section{Endereço: ***}

e-mail: ludimat@gmail.com

\section{Telefone: $* * *$}

Objetivo Geral: Validar atividades de ensino para o ensino e aprendizagem de expressões algébricas junto a professores do Ensino Fundamental Anos Finais.

Número de participantes e local da pesquisa: Participarão da pesquisa professores de matemática do Ensino Fundamental Anos Finais, a pesquisadora e a assistente de pesquisa. As atividades serão desenvolvidas no Departamento de Matemática da Universidade de Brasília, no Laboratório de Ensino de Matemática. Durante a sessão o grupo participante não será interrompido e nem receberá pessoas estranhas às atividades de pesquisa. Partes da sessão será filmada pela assistente de pesquisa.

Procedimentos: se concordar em participar da pesquisa, você participará da sessão na qual estarão presentes todos os participantes e a pesquisadora. Nessa ocasião será proposto: diálogo a respeito do processo de ensino e aprendizagem do conteúdo expressões algébricas; análise e validação de três atividades de ensino; reelaboração (individual ou coletiva) de uma proposta de ensino a partir das atividades analisadas.

Parte da sessão será gravada em vídeo e transcrita. Informações da sessão precedente poderão ser apresentadas em outra sessão, caso esta aconteça, expondo falas particulares e/ou conclusões do grupo para análise. A prgdução escrita particular e/ou do grupo será 
recolhida ao final da sessão e poderá ser utilizada parcialmente ou na íntegra, em outra sessão, caso houver. Falas particulares e/ou do grupo serão usadas no texto final da Dissertação com o consentimento do participante, respeitando e preservando em sigilo a identidade do mesmo.

Riscos e Desconfortos: Durante a sessão o participante poderá sentir-se constrangido ao ser contestado e/ou criticado em suas respostas/falas.

Benefícios: A sua participação nessa pesquisa será uma oportunidade de crescimento pessoal e profissional, uma vez que, serão discutidas questões centrais para a prática docente em matemática do conteúdo curricular expressões algébricas; conteúdo esse que permeia todo o Ensino Fundamental. Aos participantes que almejam continuar seus estudos ingressando em cursos de pós-graduação, a experiência será valiosa oferecendo um primeiro contato com as atividades de coleta, organização e análise de dados, etapas centrais na concepção e execução de pesquisa científica em qualquer área do conhecimento.

Custos: Não haverá nenhum gasto com material de consumo, didático ou de qualquer espécie. O participante é responsável pelas despesas de deslocamento até a Universidade de Brasilia e não receberá nenhum pagamento pela sua participação.

Confidencialidade: Nenhum dado será apresentado no texto final da Dissertação sem o consentimento prévio dos participantes.

Ludimila Cássia Coelho de Andrade

Matrícula:

Pesquisadora Responsável 
Potências e Raízes - ANTES DAS JOGADAS

Navio: NN (quantidade $=4$ )

Submarino: SSS (quantidade $=4$ )

MENINOS

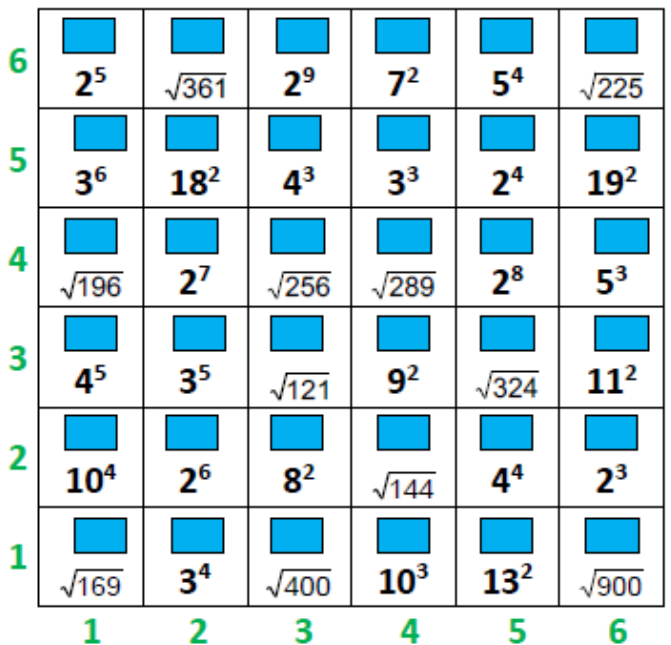

MENINAS

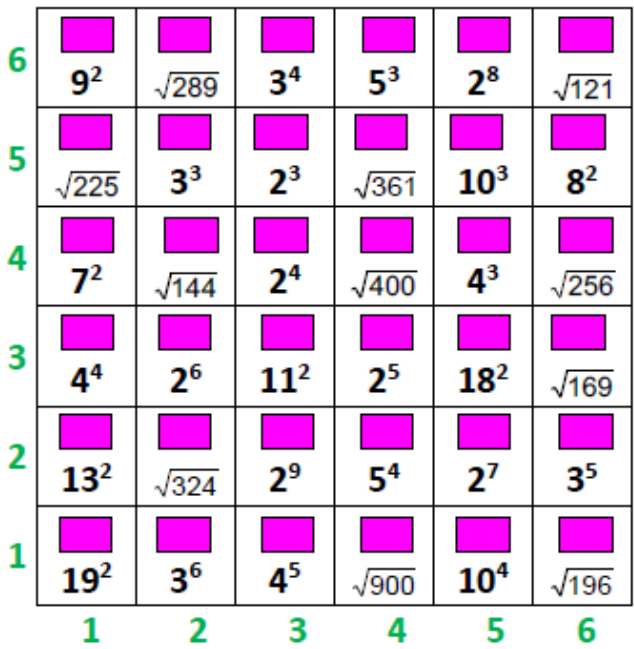

Figura A.5: Atividade Potências e Raízes elaborada por P1 - momento 1

Potências e Raízes - APÓs AS JOGADAS

Navio: $\mathbf{N N}$ (quantidade $=4$

Submarino: SSS (quantidade $=4$ )

MENINOS

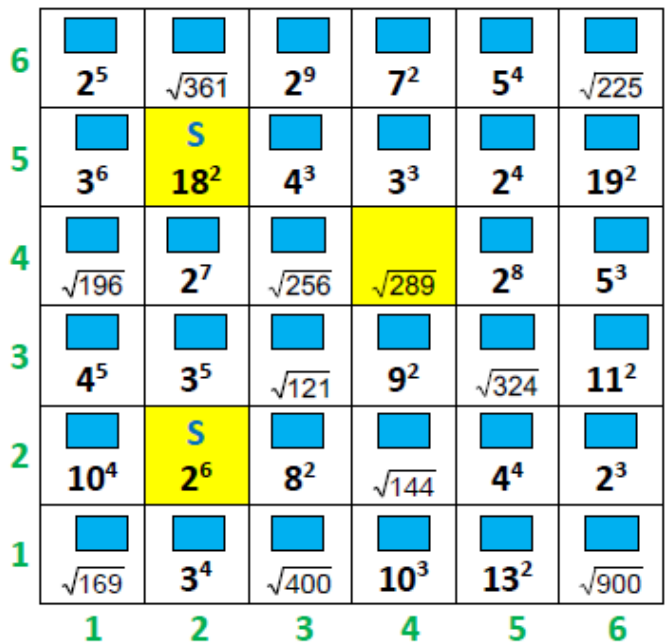

MENINAS

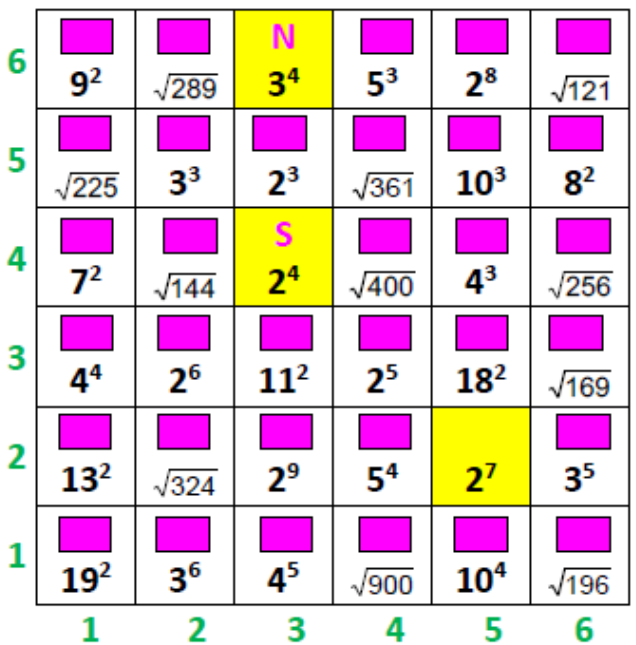

Figura A.6: Atividade Potências e Raízes elaborada por P1 - momento 2 
Inteiros na Reta - APÓS AS JOGADAS

Navio: $\mathbf{N N}$ (quantidade $=4$ )

Submarino: SSS (quantidade $=5$ )

MENINOS

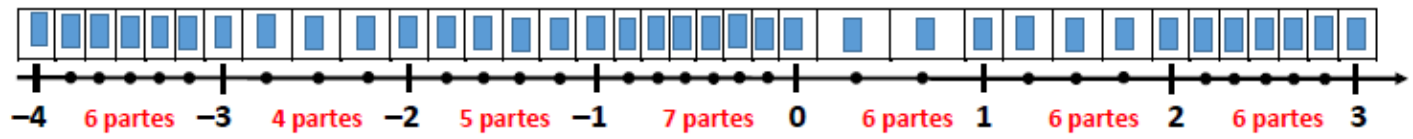

MENINAS

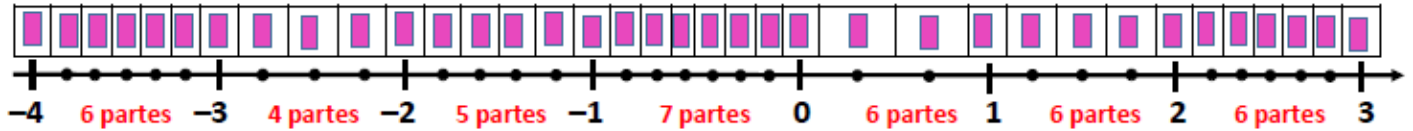

Figura A.7: Atividade Inteiros na Reta elaborada por P1 - momento 1

\section{Inteiros na Reta - APÓS AS JOGADAS}

Navio: $\mathbf{N N}$ (quantidade $=4$ )

Submarino: SSS (quantidade = 5)

MENINOS

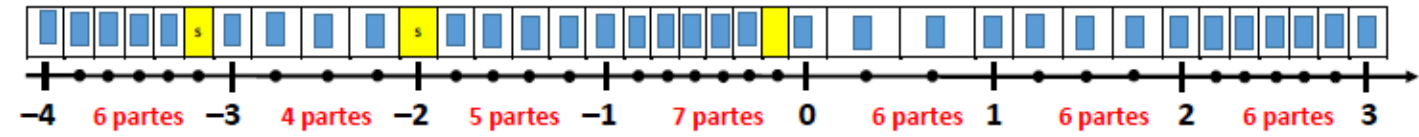

MENINAS

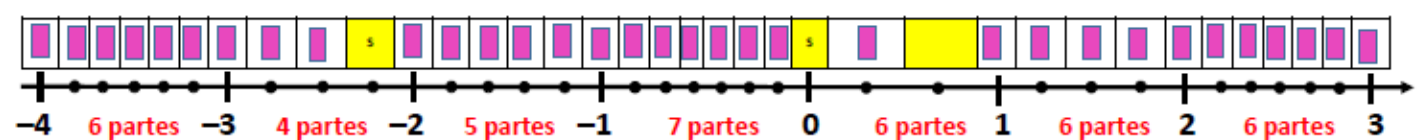

Figura A.8: Atividade Inteiros na Reta elaborada por P1 - momento 2 